\title{
THE CONSTITUTIONAL INCOMPLETENESS THEOREM
}

\author{
John F. Muller ${ }^{*}$
}

\begin{abstract}
In this Article, I argue that some truths about our constitutional order are best left misunderstood. I do so by defending a self-deception at the core of our discourse on constitutionalism. We tend to speak as if our constitutional system rests upon an uncompromising inquiry into constitutional meaning. Yet all viable interpretive theories privilege some concerns above such meaning, however they define it. This paradox, I argue, arises from the tension between parallel constitutional commitments to Enlightenment thought and the common law tradition. The paradox preserves, in my view, an appearance of coherence that is as vital as it is false. In elevating an Enlightenment ideal that belies our common law culture, we perpetuate a redemptive vision of constitutionalism capable of binding us together even as conflicts over constitutional meaning drive us apart.
\end{abstract}

\section{TABLE OF CONTENTS}

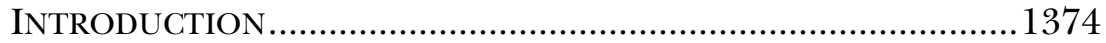

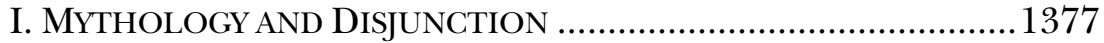

A. The Mythology of Law ............................................ 1378

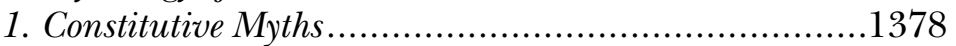

2. Legal Fictions .....................................................1380

3. Legal Myths ......................................................1382

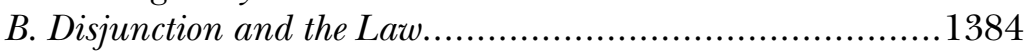

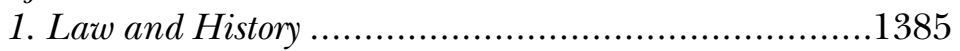

* Climenko Fellow and Lecturer on Law, Harvard Law School. My thanks to Bruce Ackerman, and to Bo Burt, Guido Calabresi, Dan Kahan, Martha Minow, and Joe Singer. All errors are mine alone. The title was inspired by Kurt Gödel's incompleteness theorems, which were introduced in his 1931 article, Über formal unentscheidbare Sätze der Principia Mathematica und verwandter Systeme I, translated in KURT GÖDEL, ON FORMALLY Undecidable Propositions of Principia Mathematica AND ReLated SYSTEMs (Bernard Meltzer trans., Basic Books 1962) (1931). 


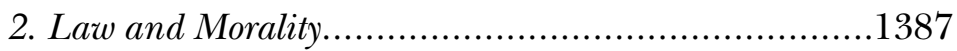

3. Law and Practice...................................................1390

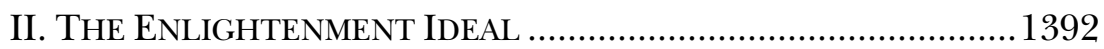

A. The Founding and Enlightenment ................................ 1392

B. Interpretation and Enlightenment .................................1398

C. Mythology, Disjunction, and Enlightenment.....................1404

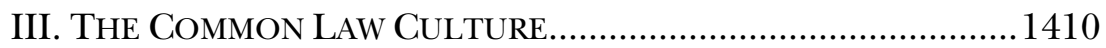

A. Justiciability ........................................................ 1411

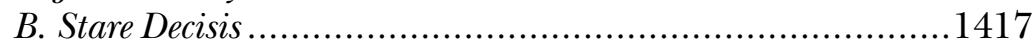

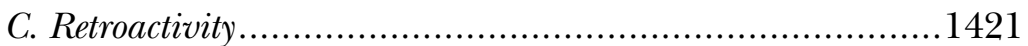

D. Dicta and Writing Separately................................ 1426

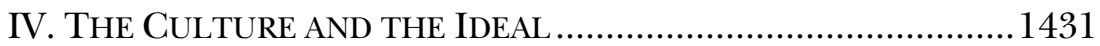

A. The Path of Absolutism .............................................. 1432

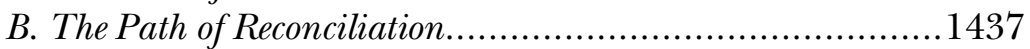

C. The Path of Contradiction ............................................. 1440

V. THE IdEAL AS BENEFICIAL LEGAL MYTH................................1445

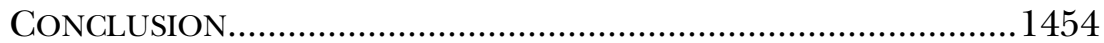

\section{INTRODUCTION}

Suppose you are convinced. You ascend Mount Sinai and behold a vision of constitutional truth. It is not a vision of constitutional commandments; earlier pilgrims to Sinai etched the commandments of American government into the written Constitution. Here on Sinai, those pilgrims divined the true constitutional text. At the same spot, you behold something different: the intricacies of constitutional practice, past and present. If those past pilgrims followed in Moses's footsteps as transcriber of the Ten Commandments, ${ }^{1}$ you follow in his footsteps as transcriber of the Torah. ${ }^{2}$ At least, you will if you share your vision with the public.

1 This reference, of course, is to Moses's ascent to Mount Sinai. There, God "gave unto Moses ... two tables of testimony, tables of stone, written with the finger of God." Exodus 31:18 (King James).

2 Rabbinic scholars have long held that Moses transcribed the first five books of the Torah through divine inspiration atop Mount Sinai. See Richard Elliott FriEdman, Who WROTE THE BIBLE? 17-32 (1987). 
The parallel with the Torah betrays both the promise and the limits of your vision on Sinai. You perceive every detail that circumscribes the Constitution, from the intentions of the Framers, to the thinking of individual judges, to the evolving preferences of the citizenry. For you, what was once unknowable becomes knowable. You may assess empirical claims about the facts now available to you, and you may assess the fidelity of theories that transform those facts into constructions of constitutional meaning. ${ }^{3}$ Yet your vision cannot ensure interpretive agreement as to constitutional meaning. Sinai does not somehow provide a constitutional "view from nowhere." The Constitution contains no commandment specifying how it is to be interpreted, and even if it did, that commandment would require interpretation. ${ }^{5}$ Your vision might make a theory more attractive than others, but it cannot settle ultimate questions of meaning. ${ }^{6}$

Still, revelation yields possibility. Suppose you return from Sinai and perceive that our contemporary constitutional order is rife with falsehood and misunderstanding. Some people purposefully misrepresent constitutional truth in order to reach certain outcomes. Others fail to see what they miscomprehend. Falsehoods and misunderstanding both create and obscure inconsistencies within interpretive accounts of constitutional meaning. That is, suppose the people fail to arrive at the constitutional meaning dictated by different interpretive approaches because they miscomprehend the sources underlying that meaning. Here lies the possibility. Perhaps, the people will heed your newfound wisdom and eliminate the falsehoods and incongruities that pervade our constitutional order. What do you tell them? Do you follow Moses and share the truth?

This may seem like an odd set of questions. Of course you share the truth-or so holds conventional wisdom. Falsehood and misun-

3 In this Article, the term "constitutional truth" refers to empirical facts relevant to constitutional interpretation. By contrast, the term "constitutional meaning" refers to the conclusions drawn from empirical facts through the act of interpretation. For further discussion on the distinction between empirical fact and interpretive conclusions from the perspective of Mount Sinai, see infra Part I.A.3.

4 In his "View From Nowhere," Thomas Nagel sought to "combine the perspective of a particular person inside the world with an objective view of that same world, the person and his viewpoint included.” THOMAS NAGEL, THE VIEW From NOWHERE 3 (1986).

5 Notably, however, the Constitution does contain language addressing how it should not be interpreted. The Ninth Amendment provides that " $[t]$ he enumeration in the Constitution, of certain rights, shall not be construed to deny or disparage others retained by the people." U.S. CONST. amend. IX.

6 For the same reason, only the original constitutional text can become apparent on Sinai. To recognize subsequent alterations to the text requires a theory of interpretation as to their legitimacy. 
derstanding threaten to distort the true meaning of our constitutional commandments. Fidelity to those commandments, however, conceived interpretively, is the overarching project of constitutionalism. Constitutional theorists labor to unearth truth about our constitutional system in order to perfect the fidelity of practice. Litigants labor to reveal the truth of constitutional meaning, even if that truth has long been hidden from the courts. Judges parse the legal interpretations presented by litigants with an eye for the truth. Or, so the narrative goes. We seek coherence in law and rue misunderstandings that allow inconsistencies to persist. The course for you, then, is clear: speak and be thorough.

I will push back against this conventional wisdom. I hope to convince you to proceed from Sinai with trepidation. As you descend from Sinai, I argue, you should think about what should be spoken and what should remain unspoken.

Rather than delve into how you might address particular revelations uncovered on Sinai, I take aim at the conventional wisdom itself. I contend that the notion that we must share our visions from Sinai is a valuable self-deception at the core of our constitutional order. This argument combines a descriptive claim with a normative one. Descriptively, I argue that our constitutional order does not share the conventional view's unwavering disdain for falsehood and inconsistency. Normatively, I argue that our acceptance of falsehood and inconsistency is vital to the survival of that order. From this, it follows that there is at least one truth visible from Sinai that would best remain unspoken.

The descriptive argument develops a dichotomy between two polar elements present in our constitutional order: the common law culture and the Enlightenment ideal. Born of the Enlightenment, our constitutional system carries forward a tradition steeped in the notion that we may reason to an understanding of abstract political truth. In this vein, we view the Constitution as an instrument of truth that eschews the falsehood and inconsistency that afflicted prior political orders. Yet, while the Constitution may have been born in a time of enlightenment, it was also born within a common law tradition. That tradition is not impervious to conceptual order and the dictates of abstract reason, but in many ways it actively preserves the mythology and disjunction decried by Enlightenment thought. We speak of the Constitution as an Enlightenment project, yet we practice constitutionalism in a manner antithetical to the Enlightenment tenets we espouse. This contradiction persistently evades recognition. 
The normative argument defends this state of affairs. In isolation, neither the common law culture nor the Enlightenment ideal adequately advances our collective constitutional goals. Accordingly, we face a choice of either setting boundaries between these two strands of constitutional thought and preserving a state of either latent or overt contradiction between them. I argue that no satisfying and precise boundaries exist between the common law culture and the Enlightenment ideal, a claim to which our constitutional discourse can readily attest. Recognizing the present state of contradiction between the common law culture and the Enlightenment ideal, moreover, would threaten the stability of our constitutional order. A state of latent contradiction, by contrast, would maintain an appearance of order and principle within our constitutional system that is, in my view, vital to its preservation. On Sinai, then, you should refrain from exposing the mythic quality of the Enlightenment ideal.

This Article proceeds as follows: Part I develops a typology of the mythology and disjunction that you might discern on Sinai. Part II introduces the Enlightenment ideal through the lens of mythology and disjunction. Part III discusses how our common law culture undermines the Enlightenment ideal, again through the lens of mythology and disjunction. Part IV discusses how scholars have navigated the tension between the common law culture and the Enlightenment ideal. Part V defends the Enlightenment ideal as a beneficial legal myth opposed to mythology and disjunction. I conclude with a return to the questions you face atop Mount Sinai.

\section{MYThOLOGY AND DisJUnCTION}

All theories of constitutional interpretation take facts and pass them through an interpretive mechanism to discern constitutional meaning. I employ the term mythology to capture misstatements of the facts that underlie theories of constitutional meaning. I employ the term disjunction to capture inconsistencies between those facts and the conclusions of law advanced by a constitutional theory. In a broad sense, then, mythology connotes fantastical notions about what I have called constitutional truth. Disjunction, by contrast, describes interpretive inconsistency that arises from mythology. As we will see, all theories of constitutional interpretation must develop a theory of the acceptability of mythology and disjunction. Your task on Sinai is to develop such a theory. 


\section{A. The Mythology of Law}

Few legal scholars have sought to define mythology precisely. The term is often applied to both seemingly objective untruths and to highly contested interpretive claims. Although scholars in other fields have spent considerable energy on conceptualizing myth, they have not advanced a uniform view. I do not seek to present a novel account of the meaning of mythology, but rather to distinguish between understandings invoked elsewhere. For our purposes, I distinguish between three types of myths, which I call constitutive myths, legal fictions, and legal myths.

\section{Constitutive Myths}

Constitutive myths establish the collective cultural meaning of a social order. In Robert Cover's terms, constitutive myths generate nomoi. $^{7}$ They produce normative meaning "in the history of ordinary legal doctrine at work in mundane affairs; in utopian and messianic yearnings, imaginary shapes given to a less resistant reality; in apologies for power and privilege and in the critiques that may be leveled at the justificatory enterprises of law." ${ }^{8}$ These myths constitute society through narrative. They bind us into a collective consciousness and divide us into distinct communities of meaning.

This notion of constitutive myth stretches more broadly than many traditional notions of myths applied to folklore. Scholars have often cast myth as a narrative that generates meaning. As Ernest Cassirer writes, myth is "the art of expressing, and that means of organizing, [man's] most deeply rooted instincts, his hopes and fears." Yet the distinguishing feature of myth in many accounts rests in its fantastical quality. It is an illusion of the mind, ${ }^{10}$ a primordial story of a time before time, ${ }^{11}$ a phantasmagoria. ${ }^{12}$ Such accounts return, time

7 Robert M. Cover, The Supreme Court 1982 Term-Foreword: Nomos and Narrative, 97 HARV. L. REV. 4, 4 (1983) (defining a nomos as a "normative universe" that defines what is "right and wrong," "lawful and unlawful," and "valid and void").

$8 \quad$ Id. at 9.

9 ERnst Cassirer, The Myth of THE STATE 48 (1946).

10 MaX Muller, Lectures on the Science of Language 21 (N.Y., Charles Scribner 1862) (describing mythology as "the bane of the ancient world" and a "disease of language" that only assumes meaning in the mind).

11 Mircea Eliade, MYTH AND REAlity 5-6 (Willard R. Trask trans., 1963) ("Myth narrates a sacred history; it relates an event that took place in primordial Time, the fabled time of the 'beginnings."”).

12 CASSIRER, supra note 9, at 23 ("As these beliefs are in open contradiction to our senseexperience and as there exist no physical objects that correspond to the mythical representations it follows that myth is a mere phantasmagoria."). 
and again, to some notion of truth. Mythology, the reasoning goes, departs from the truth of our objective reality. ${ }^{13}$ In so doing, it may either propagate dangerous falsehood or promote a transcendent truth.

In the sense described here, by contrast, a constitutive myth has no necessary relationship with an external reality or truth. The distinguishing feature of a constitutive myth rests in its shared significance for a social group. Constitutive myths, therefore, may be firmly rooted in fantasy or firmly rooted in reality. ${ }^{14}$ The distinction between historical narrative and constitutive myth is a blurred one. History may be regarded as constitutive myth when it is canonized as a source of shared cultural meaning. At such point, the narrative's basis in historical reality becomes less important than the significance we ascribe to it. ${ }^{15}$ Of course, as historical narrative takes on this role, its historical roots may become more tenuous over time. Yet fidelity may be just as constitutive as infidelity.

Given that constitutive myths generate conceptions of truth, it may seem incongruous to place them within a typology of charges of misunderstanding. As we will see, legal fictions and legal myths challenge constitutive myths against an external notion of truth. That is, constitutive myths represent the challenged misunderstandings. In a world unconcerned with external measures of truth, however, constitutive myths represent the only relevant baseline against which to level charges of misunderstanding. Rather than assert that a given understanding misstates truth in some fundamental sense, we would assert that said understanding misstates our shared system of meaning. To misunderstand would be to subscribe to constitutive mythology not shared by the public.

Consider a few examples of prevailing constitutive myths. The most obvious relate to the Founding. The Founding breathes life into present visions of America as a social contract, a republican experiment, a bastion of equality. The same narratives flow through our understanding of Reconstruction and the Civil Rights Movement.

13 For a statement to this effect in legal scholarship, see Arthur S. Miller, Myth and Reality in American Constitutionalism, 63 TEX. L. REv. 181, 206 (1984) (reviewing DON PRICE, AMERicA's UnWRitTEN CONSTITUTION: SCIENCE, REligion, AND POlitical RESPONSIBILITy (1983) and Herbert MCClosky \& Alida Brill, Dimensions OF TOLERANCE: What AMERICANS Believe ABout Civil Liberties (1983)).

14 As Rollo May writes, a "myth is a way of making sense in a senseless world. Myths are narrative patterns that give significance to our existence." ROLLO MAY, THE CRY FOR MYTH 15 (1991).

15 Recently, Chiara Bottici has highlighted this notion among longstanding accounts of myth. See Chiara Bottici, A Philosophy OF Political Myth 179 (2007). 
They also set the boundaries of the canons of admirable (and deplorable) sources invoked to establish meaning. ${ }^{16}$ It is not hard to challenge the historical integrity of such narratives. Yet these narratives represent important pillars of our social understanding.

\section{Legal Fictions}

Legal fictions denote socially recognized distortions of empirical fact employed to manipulate legal meaning. Although the notion of legal fiction has a rich history in the law, scholars have struggled to reach a consensus as to its meaning. They generally agree that legal fictions are falsehoods introduced to evade results dictated by a formal notion of law. They also generally agree that these falsehoods are a product of judicial creation, particularly in the common law mold. The legal fiction, according to a recurrent trope, fosters the law's development "like a scaffolding... that... can be removed with ease." ${ }^{17}$ Falsehoods once necessary to achieve a result become unnecessary with the advance of the law. Scholars disagree, however, on two important dimensions.

First, they disagree as to the necessary visibility of the falsehood underlying a legal fiction. For some, like Jeremy Bentham and Henry Maine, the legal fiction actively deludes the public in order to legitimate departures from the law. ${ }^{18}$ For others, like William Blackstone, the legal fiction denotes an expedient falsehood that does not intend to deceive but may nonetheless confuse. ${ }^{19}$ For still others, like Lon Fuller and Roscoe Pound, the legal fiction can neither confuse nor

16 Constitutive myths define what is accepted in the canons of constitutional law, what is rejected in those canons, and what remains a matter of dispute. See generally J.M. Balkin \& Sanford Levinson, Commentary, The Canons of Constitutional Law, 111 HARV. L. Rev. 963, 968 (1998) (discussing what ought to be "canonical in the study of law").

17 LON L. FULlER, LEGAL Fictions 70 (1967).

18 See JeREMY Bentham, Preface Intended for the Second Edition of the Fragment on Government, in A COMMENT ON THE COMMENTARIES AND A Fragment ON GOVERNMENT 509 (J.H. Burns \& H.L.A. Hart eds., 1977) (defining fiction as "a wilful [sic] falsehood, having for its object the stealing [of] legislative power, by and for hands, which could not, or durst not, openly claim it,-and, but for the delusion thus produced, could not exercise it"); HENRY SUMNER MAINE, ANCIENT LAW: ITS CONNECTION WiTH THE EARLy History OF SOCIETY AND ITS Relation to MODERN IdEAS 25 (N.Y., Henry Holt \& Co. 1878) (defining legal fiction "to signify any assumption which conceals, or affects to conceal, the fact that a rule of law has undergone alteration, its letter remaining unchanged, its operation being modified").

19 Blackstone implied that much of the power of the legal fiction lay in deception, which harmed a government based on popular representation. 3 WILLIAM BLACKSTONE, COMMENTARIES *267-68. He defined legal fiction as an arbitrary "expedient" more than an instrument of deception, however. Id. 
deceive..$^{20}$ The notion of legal fiction, then, has alternately described both transparent and opaque falsehoods as well as falsehoods that straddle the boundary between these poles.

Second, scholars disagree as to the type of falsehood that characterizes a legal fiction. This disagreement has been less fully explored in the literature. For Bentham and Blackstone, falsehood denotes a recognizable departure from empirical fact. ${ }^{21}$ For Pound, by contrast, falsehood includes both distortions of empirical fact and distortions of more theoretical concepts like equity and natural law. ${ }^{22}$ These approaches rely on a transcendent notion of truth. For Fuller, by contrast, the legal fiction denotes distortion of a collective notion of truth rather than a transcendent one: if we all agree that a statement is false, then it is false for purposes of labeling it a legal fiction. ${ }^{23}$

In the sense described here, legal fictions follow Fuller and Pound's notion of transparency and Bentham and Blackstone's notion of truth. Consider first the question of falsehood. Given its reliance on a collective notion of truth, Fuller's notion of legal fiction can best be described as a genre of constitutive myth: social meaning derives from our simultaneous affirmation and denial of a statement of truth. I employ the notion of legal fiction to assess constitutive mythology against a transcendent standard: your vision from Sinai. For reasons I address in the succeeding Subpart, Sinai can only promise a transcendent standard of empirical fact. Consider next the question of visibility. I distinguish between recognized and unrecognized falsehoods. I call the former legal fictions and the latter legal myths. I discuss legal myths in the next Subpart.

This view of legal fiction has a few consequences that depart from conventional views. First, legal fictions are not necessarily a product

20 See FULLER, supra note 17, at 9 ("A fiction is either (1) a statement propounded with a complete or partial consciousness of its falsity, or (2) a false statement recognized as having utility.”); Roscoe POUnd, InTERPRETATIONS OF Legal History 131 (1923) (defining fiction as an instance when a judge claims that "a sacred or authoritative text means what it palpably did not mean or covers what no one had in mind when it was promulgated").

21 Neither scholar made this point explicitly. Bentham described the legal fiction as "falsehood, the irreconcilable enemy of justice-falsehood, under the name of fiction - [that] is passed off by [judges] upon the deluded people" for convenience. JEREMY BENTHAM, The Elements of the ART Of PAcking, in 5 The Works OF Jeremy Bentham 92 (John Bowring ed., 1843). Blackstone described legal fictions as "minute contrivances" and "circuities." BLACKSTONE, supra note 19, at*268.

22 POuND, supra note 20, at 131 (identifying "the bolder and more general fictions of interpretation, equity and natural law").

23 FULLER, supra note 17, at 11-12 ("A statement must be false before it can be a fiction. Its falsity depends upon whether the words used are inaccurate as an expression of reality. But the inaccuracy of a statement must be judged with reference to the standards of language usage."). 
of judicial imagination. They may underlie decisions concerning legislative and even constitutional enactments. Second, we may collectively believe that a statement is a legal fiction even though it is not. That is, we may be mistaken in our belief that a statement is false.

With these two caveats in mind, consider a few doctrines described with reference to legal fiction. The doctrine of sovereign immunity has long been identified as rooted in false claims about the intent of the framers of the Eleventh Amendment. ${ }^{24}$ The originalist justification of the incorporation of the Bill of Rights has come under similar assault as resting on false claims about the framers of the Fourteenth Amendment. ${ }^{25}$ Each of these doctrines, of course, may be justified on grounds other than original intent. Such justifications would render the commonly asserted legal fictions irrelevant. Of course, they would also raise the possibility of a different set of legal fictions.

\section{Legal Myths}

Legal myths designate unrecognized distortions of empirical fact that underlie legal meaning. A legal myth is identical to a legal fiction except in that it goes unnoticed. The notion of opaque falsehood has been more scantly theorized in legal literature than the notion of transparent falsehood. Literature on legal fictions straddles this divide, but the view that legal fictions must be visible is fairly standard. ${ }^{26}$ Scholars typically use myth as a generic term to designate a broad notion of misunderstanding. ${ }^{27}$ This common usage denotes as myth misunderstandings of truth as the speaker defines it, whether they be misunderstandings of empirical or theoretical claims.

Empirical claims can be assessed definitively given adequate observational tools. Of course, tools are seldom adequate. What you are thinking right now is an empirical question, but the rest of us do not have a tool that can reveal it definitively. Where you were born, by contrast, is a question that we can determine through historical

24 See, e.g., Vicki C. Jackson, The Supreme Court, the Eleventh Amendment, and State Sovereign Immunity, 98 YALE L.J. 1, 4 (1988) ("The Eleventh Amendment ... has long been perceived as a doctrinal abyss, replete with the inconsistencies borne of pragmatic adjustments to the principle for which it supposedly stands.").

25 See, e.g., Duncan v. Louisiana, 391 U.S. 145, 172 (1968) (Harlan, J., dissenting).

26 But see Peter J. Smith, New Legal Fictions, 95 GEO. L.J. 1435, 1437 (2007) (describing both patent and latent falsehoods as legal fictions).

27 See, e.g., John Hart Ely, The Irrepressible Myth of Erie, 87 HARv. L. REv. 693, 704-05 (1974) (describing the application of the Erie doctrine to the Federal Arbitration Act). 
records. ${ }^{28}$ It is important to note that answers to empirical questions like these must inhabit a broader normative context. Consider the question of where you were born. To answer this, we must know who you are, what it is to be in a place, what it is to be born, and so on. In the abstract, these questions demand deeply theoretical answers. Within a normative context, however, their answers are an accepted element of social meaning. Those answers are also sufficiently specific to allow us to test observations against fixed points. ${ }^{29}$

Theoretical claims, by contrast, cannot be definitively assessed, regardless of the available observational tools. Let us distinguish between two types of theoretical claims. First, there are claims that concern imprecisely defined elements of a normative context. Consider the claim that you are a just person. Our social structure may espouse a notion of what it means to be a just person, but that notion is not specific enough to allow us to assess definitively whether you meet it. Second, there are claims that concern what a normative context should look like. Consider the claim that justice requires that all people have computers. This claim is intelligible given that it occupies a normative structure; otherwise, we could not communicate the idea of justice, the idea of computers, and so on. The claim itself, however, seeks to define normative meaning rather than assess compliance with it. Each claim yields debate rather than measurement. ${ }^{30}$

The notion of falsehood underlying legal myth-and legal fiction-refers to distortions of empirical claims but not distortions of theoretical claims. You arrive on Sinai as an occupant of a distinct normative context, that of modern American society. Your vision illuminates facts within that context with tools beyond our technological powers. Like no other American, you see the historical record, and so on.

29 My aim here is not to make any deep epistemological claims about the viability of empiricism as a manner of seeking truth. Rather, I seek to capture an aspiration of our constitutional discourse to nail down certain "facts" as a precondition to addressing questions of interpretation that cannot solely be resolved with reference to these supposed facts. A recurring critique of constitutional theory charges that theorists jump to the questions that elude pure factual resolution without adequately engaging the empirical questions capable of such resolution. See, e.g., Richard A. Posner, Against Constitutional Theory, 73 N.Y.U. L. REV. 1, 3 (1998).

30 As these distinctions should make clear, the line between empirical claims and theoretical claims is more slippery than often acknowledged. For purposes of this Article, however, we need not parse this boundary further. Suffice it to say, the view from Sinai makes clear which views are based in empirical fact. As we abandon the abstraction of Sinai, suffice it to say that within a normative context, the line between theoretical and empirical claims about constitutional interpretation is usually quite evident. 
social views of morality, and the intricacies of modern practice. These empirical facts deepen the enterprise of constitutional interpretation. The enterprise of interpretation, however, is theoretical; it is the task of defining normative meaning in our legal system. If we include such theoretical disagreement within our notion of falsehood, legal myth-and legal fiction-will blend into the notion of constitutive mythology. To assert falsehood would be to criticize a constitutive myth rather than to reveal its departure from an accepted notion of reality.

For our purposes, then, a legal myth is a misstatement of fact that is not apparent to the speaker. Given the absence of tools to verify every fact circumscribing our legal order, scholars are often at odds about what constitutes a legal myth. Consider Bruce Ackerman's claim that the notion that the Constitution only provides for amendment through Article $\mathrm{V}$ is a myth. This is a theoretical claim as to constitutional meaning and thus falls outside our definition of legal myth. Ackerman arrives at this theoretical conclusion, however, from the view that scholars have misrepresented historical reality concerning the Founding, Reconstruction, and New Deal. ${ }^{31}$ In our terms, Ackerman asserts that these scholars subscribe to legal myths. Other scholars dispute Ackerman's revisionist history; in our terms, they claim that he is advancing legal myths. ${ }^{32}$

\section{B. Disjunction and the Law}

Scholars have devoted less energy to theorizing about disjunction than they have to theorizing about mythology. Nonetheless, concerns about disjunction animate all fields of academic discourse. By disjunction, I mean discontinuity in the relationship between components of a theoretical construct. ${ }^{33}$ A disjunction is present when an interpretive output does not follow from interpretive inputs as demanded by a theory of interpretation. In legal discourse, disjunction denotes an instance where our conclusions of positive law fail to follow from empirical fact in accordance with the requirements set out

31 See 1 Bruce Ackerman, We the People: Foundations 34-57 (1991) (describing his constitutional theory as a rejection of the "Bicentennial Myth").

32 See, e.g., Michael W. McConnell, The Forgotten Constitutional Moment, 11 Const. CommenT. 115, 115-16 (1994) (challenging Ackerman's theory as rooted in a myth about the period between the end of Reconstruction and Brown v. Bd. of Educ.).

33 Scholars have used this term loosely to designate a disconnection or incongruity. See, e.g., PierRe SCHLAG, LAYING DOWn THE LAW: Mysticism, FeTISHISM, AND THE AMERICAN LEGAL MIND 9-12 (1996). Here, I wish to use it in a more particularized way about the internal logic of a constitutional theory. 
by a theory of interpretation. We most often speak about three types of disjunction in constitutional theory: those between law and history, law and morality, and law and practice.

\section{Law and History}

Historical inquiry rests at the core of an order built on the notion of a founding document. To discern the meaning of that document, we delve into historical moments that circumscribe it. History serves as a guide for how to treat history: interpretations of the Founding inform views of how to treat the historical moments that succeed it. Your vision on Sinai illuminates these historical moments, but it cannot tell you how they relate to one another to generate constitutional meaning. That is the task that confronts the constitutional theorist. She must elucidate an interpretive framework that explains how historical occurrences shape legal meaning, if they do at all. Constitutional interpretation, then, requires a theory that relates history to law.

Disjunctions between law and history denote instances where that theory breaks down. A theory of legal interpretation, of course, may allow for departures between law and history. Such departures do not represent disjunctions. Rather, they represent conjunctions: the theory allows the departure according to its internal metrics relating history to law. A disjunction occurs when we fail to construe substantive legal meaning in accordance with those metrics. That is, disjunction occurs when our vision of the substantive law is not faithful to either the relevant historical record or the law's interpretive guidelines. Either we misapply the proper interpretive methodology, or we properly apply that methodology to an inaccurate account of history.

A theory of interpretation could render disjunctions between law and history impossible. If you believed law were a composite of history, the range of possible disjunctions would be a null set: there would be no way law could depart from history. It is difficult to imagine such a regime, however. You might believe that the law is a code adopted at a particular moment to apply to eternity, but presumably such a code could be misapplied. ${ }^{34}$ Alternatively, if you believed that history was irrelevant to interpretation, it would make no sense to speak of a disjunction between law and history. This regime may seem more plausible than the previous one; perhaps the legal order

34 For example, we might say that a code adopted on Day Zero contains all relevant legal rules and that those rules prohibit alteration and all non-formalist interpretation. 
could address every issue de novo. The very notion of constitutionalism, however, presumes some condition precedent based in history. ${ }^{35}$

Accordingly, most, if not all, interpretive theories treat history as instructive but not dispositive. History is relevant for law but law is not history. Even the most ardent textualists look to historical usage apart from the text itself, and even the most ardent anti-textualists invoke historical practice to advance apparent departures from text. ${ }^{36}$ The most ardent originalists acknowledge that law flows from history through interpretation; no component of history is equivalent to law. ${ }^{37}$ The difficulty rests in synthesizing different historical elements and moments in history to reach a legitimate legal outcome. It should not be difficult to see the potential for disjunction that follows from this task. Disjunction may appear in the open as we examine history and the law. Or, it may hide beneath misunderstandings of facts relevant to interpretation.

Assertions of disjunction between law and history abound in constitutional discourse. Consider, for example, debates about the Court's construction of substantive due process. In Roe $v$. Wade, the majority asserted that the Due Process Clause protects rights that are "fundamental" or "implicit in the concept of ordered liberty." Court has not settled definitively on this standard, or any of its competitors. ${ }^{39}$ In dissent, however, Justice Rehnquist did not quibble with

35 This is, of course, contestable. The natural rights theorist might posit that certain rights are innate, and that the passage of time has no relation to their authority or legitimacy. For most theorists, however, time is a vital concern. As Jed Rubenfeld argues, "[s]elfgovernment is achieved by committing oneself to certain ends and holding oneself to those commitments over time. Human freedom is the freedom to write: to give one's life a text.” Jed Rubenfeld, Reading the Constitution as Spoken, 104 YALE L.J. 1119, 1145 (1995).

36 For the textualist view, consider, for example, Justice Black's famous analysis of the Bill of Rights. Hugo L. Black, The Bill of Rights, 35 N.Y.U. L. REv. 865 (1960). Black defended his view that there are absolutes in the Bill of Rights not by mere invocation of text; he invoked " $[t]$ he whole history and background of the Constitution and Bill of Rights, as I understand it." Id. at 867. For the anti-textualist view, consider, for example, Jack Balkin's critique of Raoul Berger's originalist views. Balkin argued that "we have rejected Berger's history because we know that the meaning of the Constitution is essentially historical-that it is a meaning which works itself out through history." J.M. Balkin, Constitutional Interpretation and the Problem of History, 63 N.Y.U. L. REV. 911, 953-54 (1988) (reviewing RaOul Berger, Federalism: The Founders' DEsign (1987)).

37 Consider once more Justice Black's argument that there are absolutes in the Bill of Rights, given history and text "as I understand it." Black, supra note 36, at 867. Although originalists like Black sought to cabin judicial discretion in the act of interpretation, they do not claim to fully eliminate that discretion.

38 Roe v. Wade, 410 U.S. 113, 152 (1973) (quoting Palko v. Connecticut, 302 U.S. 319, 325 (1937))

39 The Court has also looked to the "penumbra" of the Constitution, Griswold v. Connecticut., 381 U.S. 479, 483 (1965), whether a right is "deeply rooted in this Nation's history 
the majority's standard. Rather, he asserted that the majority had distorted history and thereby misapplied the requirements of its standard. $^{40}$ In so doing, Justice Rehnquist asserted that the majority advanced a disjunction between law and history.

\section{Law and Morality}

It is more controversial to assert that constitutional interpretation contains a moral component. For some constitutional theorists, the interpretive project is wholly historical. The originalist declares that it is illegitimate to look beyond original intent. The living constitutionalist may speak in similar tones. The Constitution, she might say, represents a living document precisely because it was so envisioned by the Framers. Jack Balkin's view of originalist living constitutionalism ties these two strands in this fashion. ${ }^{41}$ So does Bruce Ackerman's theory of dualist democracy; the legitimacy of extra-textual amendment, says Ackerman, derives from the Founding view of revolutionary constitutionalism. ${ }^{42}$ Morality, for such views, is a consideration for the political branches.

Led of late by Ronald Dworkin, scholars have contested the notion that morality has no role in constitutional interpretation. ${ }^{43}$ Dworkin places moral judgments at the core of the judicial task. This does not mean that judges may read their own moral convictions into the document. Rather, Dworkin argues that judges "must regard themselves as partners with other officials, past and future, who together elaborate a coherent constitutional morality." "For Dworkin, the task of constitutional interpretation involves two steps. First, the interpreter must devise each possible constitutional theory that justi-

and tradition," Washington v. Glucksberg, 521 U.S. 702, 721 (1997) (quoting Moore v. City of East Cleveland, 431 U.S. 494, 503 (1977)), and international consensus, Lawrence v. Texas, 539 U.S. 558, 572-73 (2003) (viewing international law as instructive in combination with the standard identified in Glucksberg).

40 Roe, 410 U.S. at 174-77 (Rehnquist, J., dissenting).

41 See Jack M. Balkin, Framework Originalism and the Living Constitution, 103 Nw. U. L. REv. 549, 549 (2009) ("Original meaning originalism and living constitutionalism are compatible positions. In fact, they are two sides of the same coin.").

42 See 1 ACKERMAN, supra note 31, at 165-67 (explaining that for the Founders, the "constitutional text inaugurates the American experiment in dualism by defining a higher lawmaking process through which future generations might concentrate their political energies to make fundamental law in the name of We the People of the United States").

43 For a pair of other prominent, recent critiques of the notion that morality has no role to play in interpretation, see generally JOHN FINNIS, NATURAL LAW AND NATURAL RIGHTS 10, 30 (1980) and DAVID A.J. RICHARDS, THE MORAL CRITICISM OF LAW 23-31 (1977).

44 Ronald DWORkIN, Freedom's LAW: THE MORAL REAding OF THE AMERICAN Constitution 10 (1996). 
fies the settled principles of the prevailing constitutional scheme as a whole. ${ }^{45}$ Second, the interpreter must "judge which of these eligible readings makes the work in progress best, all things considered." The latter judgment must invoke morality, albeit subject to the constraints imposed by the political history of the community. ${ }^{47}$

So stated, Dworkin's theory depends on a notion of morality that could not be characterized as definitively false. Moral claims are hardly empirical; they are theoretical in the sense that they either (1) invoke an imprecisely defined element of our normative structure, or (2) call into question the proper contours of that structure. As Dworkin defines the role of morality in interpretation, however, moral claims must be consistent with a specific standard: the moral views of the constitutional community. Of course, the normative meaning of collective intent is not sufficiently defined to allow us to test it without additional theory. Once we define this concept, however, its evaluation begins to look empirical. Suppose a theory stipulates that collective intent only exists when a majority of citizens hold the belief in question. With appropriate tools, this is a testable proposition that would exclude many visions of morality.

It follows that invocations of morality may fall outside verifiable boundaries set by a theory of constitutional interpretation. When such invocations of morality influence legal conclusions, there is a disjunction between law and morality from the view of that interpretive theory. Disjunctions between law and morality denote instances in which a vision of positive law does not follow from an interpretive theory's guidelines governing morality. Either an interpreter does not follow the theory's requirements relating law and morality, or she does not adhere to a vision of morality within the dictates of the theory. Legal fictions and legal myths may encourage impermissible views of morality. An interpreter might advance a moral view outside the range of moral views allowed by a theory if she mischaracterizes the facts that define that range.

Of course, some theories of constitutional interpretation render the notion of disjunction between law and morality unintelligible. Strict positivist accounts present law as an operational system apart

$45 I d$. at 10-11 (arguing that judges may not read their own convictions into the Constitution "unless they find it consistent in principle with the structural design of the Constitution as a whole, and also with the dominant lines of past constitutional interpretation by other judges").

46 RONALD DWORKIN, LAW'S EMPIRE 231 (1986).

47 Id. at 255 ("[A]nyone who accepts law as integrity must accept that the actual political history of his community will sometimes check his other political convictions in his overall interpretive judgment.”). 
from moral values. ${ }^{48}$ Strict natural-law theory denies that an immoral requirement may be law. ${ }^{49}$ Yet most accounts treat morality as relevant to our construction of law but not equivalent to law itself. Originalists seek to avoid moral questions through historical fidelity, but their efforts often cloak moral judgments. ${ }^{50}$ Fundamental-rights theorists draw on the themes of natural-law theory, but they do not extend those themes to challenge enumerated constitutional provisions. ${ }^{51}$ More typically, theorists have accounted for value judgments that cannot be resolved without reference to morality. Like Dworkin, they have devised theories that cabin those judgments, whether by neutral principles, ${ }^{52}$ passive virtues,${ }^{53}$ republican dialogue, ${ }^{54}$ or something else.

Speakers in constitutional discourse frequently allege disjunction between law and morality. Contentious cases elicit assertions that the judges either misapplied or misconstrued moral principles. Consider Herbert Wechsler's critique of Brown v. Board of Education. Although Wechsler agreed with the result, he argued that the Court's decision could not find support in neutral principles applicable across the law;

48 See, e.g., John Austin, The Province of Jurisprudence Determined, at vi-viii (London, John Murray 1832).

49 See generally A.P. D'EnTREves, NATURAL LAW 115 (1951) (arguing that "law is a part of ethics").

50 For a clear articulation of this view, see David A. Strauss, Originalism, Precedent, and Candor, 22 CONST. COMMENT. 299, 301 (2005) (arguing that moral judgments inevitably enter an orignalist's interpretations, and that given the originalist creed, these judgments are covert). Even Justice Scalia, the most prominent advocate of originalism, has acknowledged this possibility. See Antonin Scalia, Originalism: The Lesser Evil, 57 U. CIN. L. Rev. 849, 864 (1989) ("The inevitable tendency of judges to think that the law is what they would like it to be will, I have no doubt, cause most errors in judicial historiography to be made in the direction of projecting upon the age of 1789 current, modern values-so that as applied, even as applied in the best of faith, originalism will (as the historical record shows) end up as something of a compromise.").

51 See, e.g., Lloyd Weinreb's critique of the natural law analysis of the Constitution advanced by David Richards in RICHARDS, supra note 43. As Weinreb argues, Richards relies on the Constitution "to establish the validity of the moral principles he applies." LLOYD L. WeinReb, NATURAl LaW AND Justice 116 (1987). Richards "has difficulty getting past what he regards as incorrectly limited moral notions contained in the Constitutionwhich, after all, accepted the institution of slavery," Weinreb argues, and ultimately his analysis "remains an analysis of the legal order according to its own premises, which are validated only within the legal order itself." Id. at 117.

52 See generally Herbert Wechsler, Toward Neutral Principles of Constitutional Law, 73 HARV. L. REV. 1, 15 (1959).

53 See generally AleXANDER M. Bickel, The LEAST DANGERous Branch: THE Supreme CourT AT THE BAR OF POLITICS (1962).

54 See generally Frank I. Michelman, The Supreme Court 1985 Term-Foreword: Traces of SelfGovernment, 100 HARV. L. REV. 4 (1986). 
that is, the court misapplied its interpretive guidelines. ${ }^{55}$ Of course, many other writers have defended Brown with a similar view of morality but a different vision of the proper role of morality in legal interpretation. For Dworkin, the decision does not represent a disjunction between law and morality; rather, it reverses a status quo built on an impermissible conception of morality given the development of social views after Plessy v. Ferguson. ${ }^{56}$

\section{Law and Practice}

Practice, like morality, has a somewhat controversial place in constitutional interpretation. Once again, the originalist will deny that present practice can legitimately enter into what should be a purely historical inquiry. Let us postpone the response to the originalist to be clear about what disjunction between law and practice is not. Scholars often identify a difference between "law in books" and "law in action. ${ }^{57}$ This difference speaks to the distance between imperative and conjunctive; that is, the law is not adequately enforced in practice. Surely, this departure between law and practice represents a contradiction in every sense of the word. It does not, however, represent a disjunction of the type with which I am concerned.

For our purposes, a disjunction between law and practice denotes an instance when conclusions of law do not follow from practice in accordance with the dictates of a constitutional theory. Social and legislative practice informs legal meaning for most theories of constitutional interpretation. Lawrence Lessig's linguistic analysis of fidelity in translation conveys this point in particularly vivid terms. ${ }^{58}$ As Lessig argues, reading constitutional text inevitably takes place within a social context. Lessig criticizes the notion that we may achieve fidelity to that text merely by determining its meaning within the context of its authors. Fidelity to any text, he argues, requires translating the meaning within the context of the authors into the context inhabited by the readers. This process requires not only an understanding of history, but also an understanding of the present. ${ }^{59}$

\footnotetext{
Wechsler, supra note 52, at 31-35.

DWORKIN, LAW's EMPIRE supra note 46, at 387-88.

For a classic statement of this dichotomy, see Roscoe Pound, Law in Books and Law in Action, 44 AM. L. Rev. 12, 22 (1910).

58 Lawrence Lessig, Fidelity in Translation, 71 Tex. L. Rev. 1165, 1166 (1993).

59 As Lessig puts the point, "[i]f context matters to meaning, and if contexts may change, then the reader focused on fidelity needs a way to neutralize or accommodate the effect that changing context may have on meaning. Fidelity, that is, needs a way of reading that preserves meaning despite changes in context." Id. at 1177.
} 
Lessig's argument is well known, and there is no need to rehash it here. His point is perhaps most clear in its application to the Eighth Amendment's prohibition on "cruel and unusual" punishment. To interpret this provision, we might look to what the Framers considered to be cruel and unusual at the time of the Founding. This, Lessig argues, would be to pronounce fidelity to the Founding context rather than the Founding meaning. The fidelity Lessig envisions, by contrast, would call upon modern interpreters to translate this prohibition into the modern context. Whereas the Framers may have viewed flogging as a permissible punishment within the Clause, modern notions of what constitutes "cruel and unusual" punishment do not. By discerning how the Framers understood the provision within their social context, we may discern an equivalent meaning within ours. $^{60}$

In theory, an interpretive approach could render comparisons between law and practice unintelligible. We might arrive at the view that practice has no necessary relationship with law. Lessig defines this view as one-step fidelity. ${ }^{61}$ If this were the case, there could not be a relevant disjunction between these unrelated elements. Or, we might arrive at the view that law simply is practice. This view would eliminate the possibility of a departure between elements that are one and the same thing. Neither of these views is very plausible, however. As Lessig argues, even self-proclaimed one-step fidelitists like Justice Scalia accept the notion of translation when it comes to transparently contextual terms like "cruel and unusual" punishment. ${ }^{62}$ To equate practice with law, moreover, would be to deny the constitutional project altogether; we would not be bound by history, morality, or any other force that transcends the present.

Most interpretive approaches openly accept the notion that practice influences legal meaning. Lessig's criticism centers on the failure of some theorists to discern the importance of translation for constitutional provisions built on words less obviously normative than "cruel and unusual." ${ }^{33}$ Translation reflects the primary project of living constitutionalism in its various forms. The notion of living constitutionalism highlights an important quality of disjunctions between law and practice: as practice changes, so will the dictates of conjunction

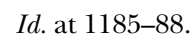

Indeed, it is more often the normative assumptions that circumscribe the words that change, rather than the particular content of the words themselves. Consider, for example, Lessig's discussion of the meaning of Article V. See id. at 1220-24. 
between law and practice. $^{64}$ Accordingly, a conjunction may transform into disjunction and a disjunction may transform into conjunction. To the extent that social views of morality change over time as well, disjunctions between law and morality will exhibit similar patterns.

\section{THE ENLIGHTENMENT IDEAL}

As you descend from Sinai, it will be difficult to ignore the path advised by a chorus of voices that echoes across our constitutional landscape. This is the path of the Enlightenment ideal. The Enlightenment ideal dictates three foundational principles for constitutional theorists. First, it demands a broad and deep inquiry into sources of social meaning. Second, it demands that theories of social meaning rest on assertions of fact rather than fiction. Third, it demands that theories of social meaning consistently and uniformly adhere to their own tenets. From these three principles, a fairly straightforward conclusion follows: when you return from Sinai, you should spare no effort to eliminate the mythology and disjunctions that you encounter.

\section{A. The Founding and Enlightenment}

Scholarship on the Enlightenment origins of the Constitution has fallen out of vogue. Where earlier debates assessed the influence of European Enlightenment in the Colonies, contemporary ones delve into the more uniquely American qualities of intellectual movements in the Revolutionary period. ${ }^{65}$ Nonetheless, a dominant constitutive myth of American constitutionalism continues to link the Framers with the Enlightenment. ${ }^{66}$ For modern scholars, as for Enlightenment thinkers, a definition of Enlightenment has remained elusive. I have no illusions about providing clarity in this area. Rather, I identify a particular disposition characteristic of Enlightenment thought.

Of course, these shifts must be harmonized with a theory's understanding of the relationship between law and history as well as law and morality. Shifts in the legal and non-legal presuppositions that underlie interpretation inform how we construct both the content and importance of history and morality relevant to interpretation.

65 Colin Bonwick, Enlightenment and Experience: The Virginia Constitution of 1776, in AMERICA AND ENLightenment Constitutionalism 177 (Gary L. McDowell \& Johnathan O’Neill eds., 2006).

66 Scholars often invoke the Enlightenment to categorize the Founding. See, e.g., AKHIL REED AMAR, AMERICA'S CONSTITUTION: A BIOGRAPHY 243 (2005) (noting in passing that a "general commitment to Enlightenment values (slavery aside) pulsated through the Constitution”). 
It is no surprise that Enlightenment remains a prominent motif in scholarship about the Founding. As Bernard Bailyn writes, leading Enlightenment thinkers "were quoted everywhere in the colonies, by everyone who claimed a broad awareness." ${ }^{67}$ The "pervasiveness of such citations," Bailyn notes, "is at times astonishing." ${ }^{68}$ Writers referred to Americans as "an enlightened people." ${ }^{69}$ Prominent revolutionary thinkers joined the pantheon of luminaries of the European Enlightenment. $^{70}$ For Bailyn, however, the colonists portrayed knowledge of Enlightenment that tended toward the superficial. More than an Enlightenment program, colonists conveyed awe of Enlightenment. ${ }^{71}$

A better understanding of the European Enlightenment would not necessarily have yielded a more precise Enlightenment program in the Colonies. Enlightenment is simply a label retroactively applied to a set of intellectual perspectives. ${ }^{72}$ We associate enlightenment with the advance of reason at the expense of tradition and culture. To recycle a few recurrent tropes, Enlightenment thinkers engaged in a "struggle of light against darkness,", "transforming the invisible into the visible, the ineffable into the discursive, and the unknown into the known." ${ }^{74}$ Some obvious questions arise. What is reason? Why did it oppose tradition and culture? What lay in light and in darkness? On this, Enlightenment thinkers were not of a uniform view.

At a sufficiently high level of generality, however, some patterns emerge. Consider Kant's famous dictum, "Enlightenment is mankind's exit from its self-incurred immaturity." ${ }^{, 5}$ What is immaturity? For Kant, it is "the inability to make use of one's own understanding without the

67 BERNARd BAILYN, THE IdEOLOGICAL ORIGINS OF THE AMERICAN REVOLUTION 27 (1967).

69 See Gordon S. WoOd, THE Creation OF THE AMERICAN Republic 1776-1787, at 5 (1969) (internal quotation marks omitted).

70 For a survey of these contributions, see Robert A. FERguson, The AMERICAN ENLIGHTENMENT 1750-1820 (1997).

71 BAILYN, supra note 67 , at 28.

72 Accordingly, there are many debates about to whom it should be applied and how the term should be qualified for different strands of thought, including in relation to the Framers. See, e.g., Harold J. Berman, The Impact of the Enlightenment on American Constitutional Law, 4 YALE J.L. \& HUMAN. 311, 311-13 (1992) (discussing confusion wrought by using the term "enlightenment" to describe thought emerging from the French Revolution and the English Revolution).

73 FERGUSON, supra note 70, at 25.

74 Stephen Eric Bronner, Reclaiming the EnLightenment: TOward a Politics of RADICAL ENGAGEMENT 19 (2004).

75 Immanuel Kant, An Answer to the Question: What is Enlightenment?, in WHAT Is ENLIGHTENMENT? EIGHTEENTH-CENTURY ANSWERS AND TWENTIETH-CENTURY QUESTIONS 58, 58 (James Schmidt ed., 1996). 
guidance of another." ${ }^{76}$ We must, he writes, "have the courage to use [our] own understanding." 77 How do we reach said understanding? We must aspire to thought unimpeded by " $[\mathrm{r}]$ ules and formulas, these mechanical instruments of a rational use (or rather misuse) of [our] natural gifts." ${ }^{78}$ Why employ those natural gifts? For Kant, "[o]ne age cannot bind itself, and thus conspire, to place a succeeding one in a condition whereby it would be impossible for the latter age to broaden its knowledge (particularly such pressing knowledge), to cleanse itself of errors[.]"79 Kant hardly spoke for all Enlightenment thinkers, but this provides a start.

Enlightenment rhetoric elevated notions of breadth, fact, and coherence. Like Kant, Enlightenment thinkers called for a return to first principles. In the pursuit of truth, no rock should remain unturned, no bridge untested, and no prior claim blindly trusted. ${ }^{80}$ They were not quite willing, however, to abstain from privileging a few principles above others. Inquiries into truth were to decry factual error of any kind. Truth had to exhibit some consistent logic; it could not rest on contradiction. The Enlightenment thinker was to inquire broadly into the sources of truth but within the confines of fact and logic. Of course, the details of this inquiry were a matter of debate, as were the conclusions different inquiries demanded. The Framers responded more to some Enlightenment thinkers than others; indeed, it appears that they had little knowledge of Kant. ${ }^{81}$

Ernest Gellner conveys this orthodoxy with particular clarity. For Gellner, reason denoted "the notion of a single, systematic, orderly method of the attainment of truth, incarnate in all and privileged in none." ${ }^{\prime 2}$ This notion was at once "generic" and "transcendent." Reason is generic in the sense that it requires "general considera-

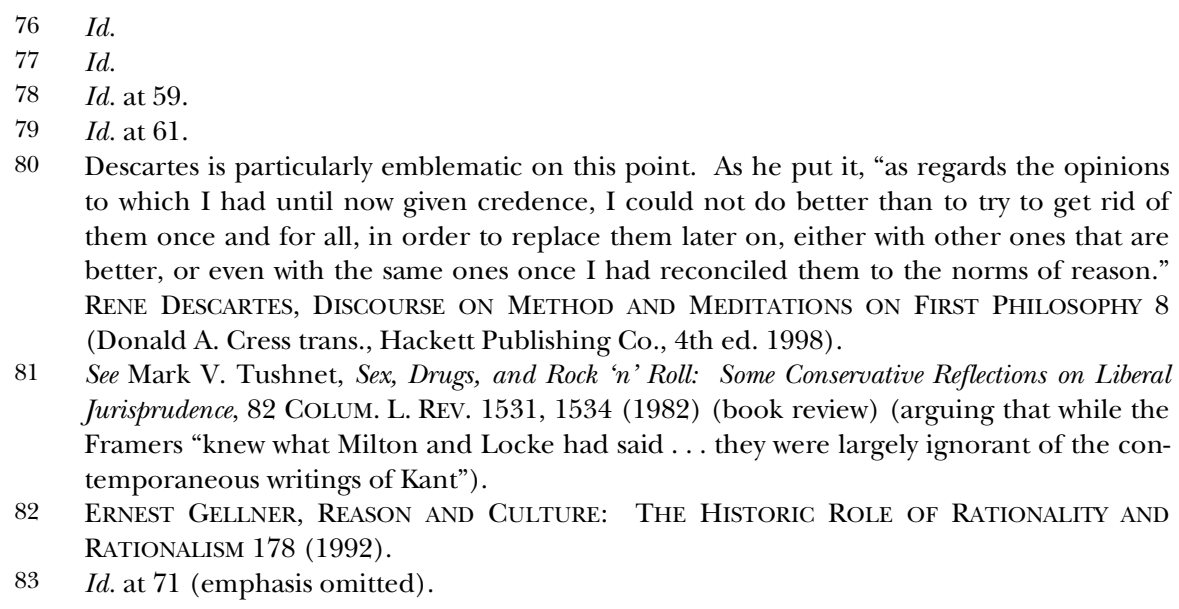
to which I had until now given credence, I could not do better than to try to get rid of them once and for all, in order to replace them later on, either with other ones that are better, or even with the same ones once I had reconciled them to the norms of reason." Rene Descartes, Discourse on Method and Meditations on First Philosophy 8 (Donald A. Cress trans., Hackett Publishing Co., 4th ed. 1998).

81 See Mark V. Tushnet, Sex, Drugs, and Rock 'n' Roll: Some Conservative Reflections on Liberal Jurisprudence, 82 Colum. L. REV. 1531, 1534 (1982) (book review) (arguing that while the Framers "knew what Milton and Locke had said ... they were largely ignorant of the contemporaneous writings of Kant").

82 ERnest Gellner, Reason and Culture: The Historic Role of Rationality and RATIONALISM 178 (1992).

$83 I d$. at 71 (emphasis omitted). 
tions" and must be both "tidy and systematic: what [reason] does, fits into a wider order." ${ }^{\prime 4}$ Reason is transcendent in the sense that "[t]he criteria she deploys, the truths she attained, are not tied to the organism, social or other, within which she happens to be functioning." ${ }^{, 85}$ In this sense, Enlightenment reason harbors an irresolvable conflict. Just as reason rejects orthodoxy governing thought, it advances an orthodoxy of its own: "[t] he notion of the exclusive, jealous and orderly deity, which had helped engender rational unificatory thought, itself in the end also sinned against it."

Given these tensions, some scholars have sought to abandon the idea of Enlightenment reason altogether. Building on the work of Margaret Jacob, ${ }^{87}$ James Q. Whitman distinguishes between reason and hermeticism. Whitman writes:

"Hermeticism" is reasoning-but it is reasoning that starts from a critical assumption: the assumption that there is a key to the universe. A person engaging in hermetic reasoning believes that the process of reason (whether inductive or deductive) will reveal some relatively simple principle or relatively coherent scheme that explains how the world works; ideally something with the simplicity and evident grandeur (to take the model most popular in [the] eighteenth century) of Newtonian gravity. It hardly needs to be emphasized that this assumption is neither required nor justified by the concept of "reason" itself.

For Whitman, hermeticism better describes many of the popular aspects of Enlightenment thought. These aspects, he argues, inherited the Ramist tradition of logic and contributed to the allure of Enlightenment movements like freemasonry. ${ }^{89}$

Consistent with Enlightenment rhetoric, Founding rhetoric emphasized breadth of inquiry, factual grounding, and structural coherence. Consider Hamilton's descriptions of the Constitution in Federalist No. 9. According to Hamilton, "[i]f it had been found impracticable, to have devised models of a more perfect structure, the enlightened friends to liberty would have been obliged to abandon the cause of that species of government as indefensible. The science of politics, however, like most other sciences has received great

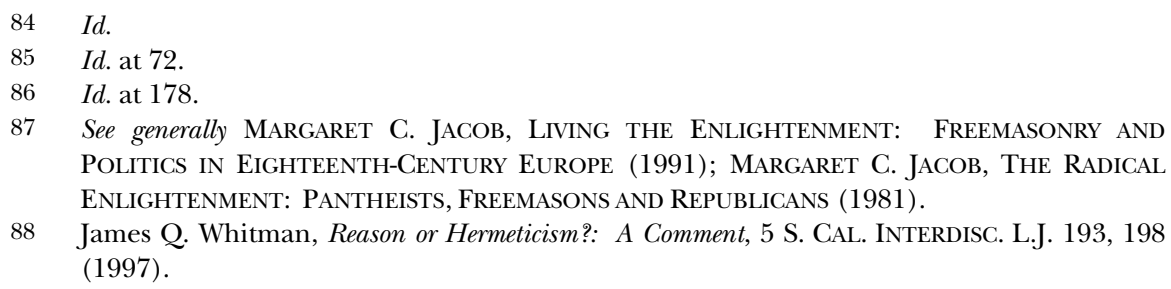


improvement." ${ }^{90}$ Through the separation of powers, checks and balances, an independent judiciary, and popular representation, Hamilton posited that "the excellencies of republican government may be retained and its imperfections lessened or avoided." tion of "new discoveries" and revived notions that had "made their principal progress towards perfection in modern times" promised a system beyond improvement. ${ }^{92}$

Hamilton's claims may seem naïve or propagandistic. Nonetheless, they capture a central element of the Founding project. As Gordon Wood puts it in his classic account, the Framers "sought to understand politics, as [they] had all of life, by capturing in an integratintegrated, ordered, changeless ideal the totality and complexity of the world. ${ }^{93}$ In the first years of the republic, the Newtonian metaphor became common in descriptions of the Constitution. ${ }^{94}$ As Whitman writes, the Founding notion of constitutionalism derived from "the idea of the 'natural' constitution of the human body, an idea ultimately borrowed from the alien world of Hippocratic medicine." ${ }^{95}$ To build a constitution required scientific inquiry into the truth of our political nature.

The Founding concern with breadth, fact, and coherence did not dictate a particular approach to constitutionalism. Henry F. May's account of Enlightenment in America is instructive in this regard. May identifies four Enlightenment movements: Moderate Enlightenment, Skeptical Enlightenment, Revolutionary Enlightenment, and Didactic Enlightenment. ${ }^{96}$ As their names suggest, these movements reached different conclusions as to how to best fashion political order according to reason. The Moderate Enlightenment defended balance and compromise akin to the English system, whereas the Skeptical Enlightenment favored absolutism of the type propounded by the French philosophes. The Revolutionary Enlightenment counseled radical breaks with past culture, whereas the Didactic Enlightenment favored incremental change and defended intellectual culture. Of course, these divisions oversimplify matters. They convey, however, the many Enlightenment paths open to the Framers.

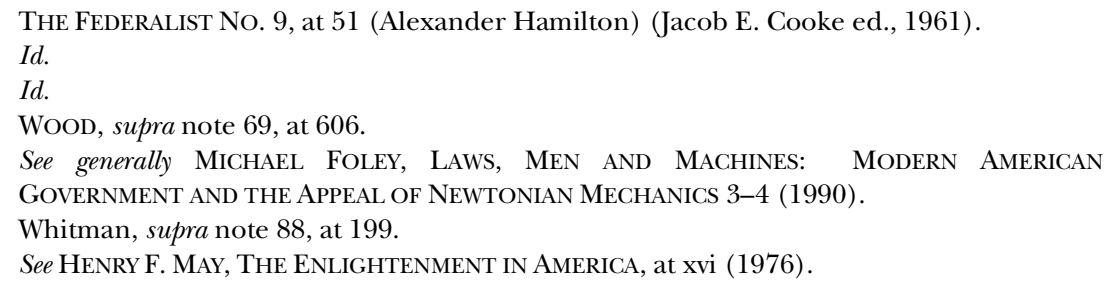


May convincingly identifies the Framers with the Moderate Enlightenment and the Didactic Enlightenment. In a much-quoted passage of Federalist No. 14, Madison notes that although the people "have paid a decent regard to the opinions of former times and other nations, they have not suffered a blind veneration for antiquity, for custom, or for names. ${ }^{97}$ The basic contours of the new constitutional order, however, followed colonial government and the English system. $^{98}$ The Framers devised a constitutional scheme to address concerns that "[e]nlightened statesmen will not always be at the helm"99 and that " $[\mathrm{t}]$ he reason of man, like man himself is timid and cautious, when left alone." ${ }^{\prime 100}$ That scheme did not veer into the more radical currents that would envelop France. This is not to say, however, that a more radical path would have been inconsistent with reason. Rather, it is to say that they reasoned to a different conclusion about the dictates of reason. ${ }^{101}$

That conclusion, to borrow a construct from Paul Kahn, sought to unify scientific reason with popular will. For the Framers, Kahn argues, scientific government would be illegitimate without consent, and popular government would be bad government without science. Accordingly, the goal of the Founding project was "to achieve popular legitimation of an objectively true political order, to found popular choice on popular, though still genuine, wisdom."102 Its success is open to interpretation, as is the question of what we should do when reason and will diverge. For Kahn, reason could not triumph over will; the Framers could not impose the true path upon the public, at least not with a clear conscience. For other theorists, reason must triumph over will; it is reason-not will-that legitimates a constitutional order. ${ }^{103}$ Such debate highlights once again the range of possible structures dictated by our three tenets of Enlightenment.

This is not to say that the Founding story can only be told with reference to the Enlightenment. We often tell a different story: that the Constitution was born of a series of compromises. ${ }^{104}$ This story

\footnotetext{
97 The Federalist No. 14, at 88 (James Madison) (Jacob E. Cooke ed., 1961).

98 This argument has been most prominently advanced in WOOD, supra note 69.

99 The Federalist No. 10, at 60 (James Madison) (Jacob E. Cooke ed., 1961).

100 The Federalist No. 49, at 340 (James Madison) (Jacob E. Cooke ed., 1961).

101 See MAY, supra note 96, at 360 (discussing the influence of the Revolutionary Enlightenment on American thought).

102 Paul W. Kahn, Legitimacy and History: Self-Government in American CONSTITUTIONAL THEORY 17 (1992).

103 This is, for example, the approach of the German Constitution.

104 For a recent articulation of this view, see John F. Manning, Clear Statement Rules and the Constitution, 110 Colum. L. REV. 399, 428-32 (2010).
} 
highlights the politics necessary to bring together disparate factions. At its most extreme, it casts the Constitution as a product of selfinterested politics of power. ${ }^{105}$ I do not intend to disparage this account. Surely, there are elements of truth in it, although it is clear that Charles Beard overstated his case. ${ }^{106}$ This view merely represents another strand running through our constitutional discourse; it does not alter the echoes of Enlightenment rhetoric that reverberate from the Founding period. As we will see, this view of the Constitution as born of compromise is harmonious with another organizing force within our constitutional system: the common law culture.

The key here is that the Framers spoke of their constitutional project as a product of breadth, fact, and coherence. Even if the new structure did not mark a transcendent break with past practice or follow an Enlightenment notion of principle, its proponents paid obeisance to enlightenment. The Framers looked to the nature of government, the nature of the American people, the nature of human ordering, and so on, seeking genuine understanding. They proposed an order that derived from those understandings and promised a Newtonian coherence. We might say that they failed. This should not, however, obscure the Founding rhetoric. That rhetoric would outlast the Founding, giving rise to dual concerns with constitutional rediscovery and constitutional perfection.

\section{B. Interpretation and Enlightenment}

By most metrics, the act of framing a constitutional order is quite different from the act of interpreting one. The former devises a system of government, whereas the latter construes the meaning of such a system. From the perspective of the Enlightenment ideal, however, these acts are of the same ilk. Recall the Hippocratic notion that each human body has a natural constitution. For the Enlightenment ideal, both the framer of a new constitutional order and the interpreter of an existing constitutional order are to discern the dictates of the constitution of the relevant political body. Both the framer and the interpreter construe the same transcendent truth. The dif-

105 For perhaps the most prominent example, see CHARLES A. BEARD, AN ECONOMIC INTERPRETATION OF THE CONSTITUTION OF THE UNITED STATES 324 (1941) (arguing that movement for the Constitution was first made by "a small and active group of men immediately interested through their personal possessions in the outcome of their labors.").

106 For a classic critique, see generally Richard Hofstadter, THE Progressive Historians 167-348 (1968). 
ference between them lies in time; the interpreter confronts a political body shaped by the framer.

Like the Framers, we speak of uncovering the dictates of our national constitution, which is to say the dictates of the composition of our collective political body. Like the Framers, we speak of that enterprise with reference to three tenets of Enlightenment: first principles, factual accuracy, and structural coherence. Unlike the Framers, however, we confront a political body with a tangible touchstone: the written Constitution. That text occupies the focal point of inquiries into the principles that animate our political order as well as inquiries into the principles that might animate our political order with reform. We invoke the language of Enlightenment both to uncover our constitution and to transform it.

Begin with the Marshall Court. Comprised of members of the Founding generation, the Court invoked the spirit of Enlightenment in order to reach results that at times sound as much of creation as interpretation. Consider the Court's most studied cases, Marbury $v$. Madison ${ }^{107}$ and McCulloch v. Maryland. ${ }^{108}$ In each, Chief Justice Marshall engages in a broad inquiry into the first principles animating the substance and legitimacy of the Constitution. He turns to a close reading of the text and an unyielding commitment to constitutional coherence. The demands of the coherent constitutional structure ratified by the people, Marshall claims, dictates each result. ${ }^{109}$ We may contest this claim; indeed, many scholars have. ${ }^{110}$ Yet, even if imperfectly or unfaithfully, the Court purported to reason to the dictates of our political constitution in accordance with the Enlightenment ideal.

With the passing of the Founding generation, courts and commentators abandoned anything resembling creation, embracing more distant notions of interpretation. When Abraham Lincoln delivered his Lyceum Address in 1838, he lamented that the Founding generation and its "pillars of the temple of liberty" had "crumbled

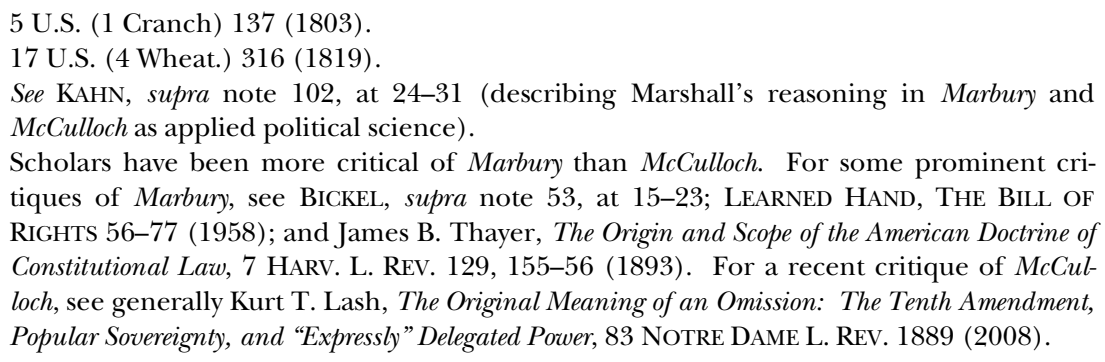
tiques of Marbury, see BICKEL, supra note 53, at 15-23; LEARNED HAND, THE BILL OF RIGHTS 56-77 (1958); and James B. Thayer, The Origin and Scope of the American Doctrine of Constitutional Law, 7 HARV. L. REv. 129, 155-56 (1893). For a recent critique of McCulloch, see generally Kurt T. Lash, The Original Meaning of an Omission: The Tenth Amendment, Popular Sovereignty, and "Expressly" Delegated Power, 83 NOTRE DAME L. REV. 1889 (2008). 
away." 111 Without those pillars, he warned, the "temple must fall, unless we, their descendents, supply their places with other pillars, hewn from the solid quarry of sober reason."112 Lincoln's prescription? "Reason, cold, calculating, unimpassioned reason," which would "furnish all the materials for our future support and defense." Modern generations needed to mold those materials into "general intelligence, sound morality, and in particular, a reverence for the constitution and laws." In so doing, they would prevent the tyranny and unreason guarded against by the framers and in much the same fashion.

Reverence may sound of a departure from the Enlightenment ideal, but it need not. Paul Kahn distinguishes between the notion of applied science advanced by the Founding generation and the notion of constitutional maintenance that emerged with Lincoln and thinkers like Joseph Story and John C. Calhoun. Whereas members of the Founding generation reasoned to a new constitutional order, Kahn argues, their immediate successors hoped merely to "maintain the edifice made by the founders." 115 Framed thusly, the effort to maintain the Constitution echoes the Founding inquiry, even if not its particular conclusions. Like the Framers, Story and Calhoun embarked upon a searching inquiry into the dictates of our national constitution. For them, that constitution rested in the Founding pact devised by the Framers. They spoke of the fundamental principles of our constitutional order and amendments that would perfect it. ${ }^{116}$ As John Norton Pomeroy wrote in 1868, "[o] ur fathers, by an almost divine prescience, struck the golden mean" in devising our political system. ${ }^{117}$ We were to reason to the "truth of history."

\footnotetext{
111 Abraham Lincoln, The Perpetuation of Our Political Institutions: Address Before the Young Men's Lyceum of Springfield, Illinois (Jan. 27, 1838), in ABRAHAM LinCOLN: HIS SPEECHES AND WRITINGS 76, 84 (Roy P. Basler ed., 2001). CONSTitution AND Government OF THE United States 12, 112 (Richard K. Cralle ed., Charleston, S.C., Walker \& James 1851) (invoking the "great principle" of the "responsibility of the rulers to the ruled" and the "fundamental principle" that "the people are the source of all power"); 1 JOSEPH STORY, COMMENTARIES ON THE CONSTITUTION OF THE UNITED STATES $\$ 338$ (Boston, Hillard, Gray \& Co. 1833) (arguing that the Constitution "is, and accordingly has always been, treated as a fundamental law, and not as a mere contract of government, during the good pleasure of all the persons, who were originally bound by it, or assented to it").

117 John Norton Pomeroy, An Introduction to the Constitutional Law of the UNITED STATES $§ 156$ (Bos., Houghton, Osgood \& Co., 4th ed. 1879). 
The substitution of Darwin for Newton shifted visions of the meaning of the Founding, but not the rhetoric accompanying their justification. Invocations of first principles remained; the principles invoked, however, called on a Darwinian notion of growth rather than an unchanging Newtonian universe. ${ }^{119}$ Consider two latenineteenth-century constitutionalists: Sidney George Fisher and C.G. Tideman. For Fisher, government was "a machine for applying principles and imposing rules of conduct essential to the well-being of a people." 120 The results it supplies may vary, but "its 'real being,' to use Plato's language, consist[s] of the idea or truth it is intended to manifest and execute." ${ }^{121}$ The set of principles devised by the Founding, Fisher argued, called for cautious growth. For Tiedeman, by contrast, the "fundamental principles which form the constitution of a state cannot be created by any governmental or popular edict; they are necessarily found imbedded in the national character."122 Tiedeman's account of the legitimacy of living constitutionalism lay in a combination of founding intent and popular will.

Writing after the turn of the Twentieth century, Woodrow Wilson spoke of constitutional growth with similar echoes of Enlightenment thought. Wilson argued that a constitution might shift in meaning over time but it cannot shift in principle. No method but the "principle of growth," he argued, "has legitimate place in a system which depends for its very life upon its integrity, upon the candor and good conscience of its processes, upon keeping faith with its standards and its immemorial promises." Judges, therefore, must "prove themselves such men as can discriminate between the opinion of the moment and the opinion of the age, between the opinion which springs, a legitimate essence, from the enlightened judgment of men of thought and good conscience, and the opinion of desire, ... of impulse and impatience." ${ }^{, 12}$ It was the task of the public, by contrast, to sustain courts capable of such inquiry into truth.

119 For a discussion of the substitution of Darwin for Newton, see, for example, Bruce Ackerman, The Living Constitution, 120 HARV. L. ReV. 1737, 1794-1801 (2007). It bears emphasis that arguments that purport to derive from first principles need not yield an unchanging Newtonian result. They may just as well yield a Darwinian notion of constitutional evolution.

120 Sidney George Fisher, The Trial of the Constitution 17 (Negro Univs. Press, 1969) (1862).

121 Id.

122 Christopher G. Tiedeman, The Unwritten Constitution of the United States 16 (Wm. S. Hein \& Co. 1974) (1890).

123 WOODROW WiLSON, CONSTITUTIONAL GOVERNMENT IN THE UNITED STATES 159 (1908).

124 Id. at 172. 
The Enlightenment ideal is on display, as well, in the scientific approaches to constitutionalism that would reach their apex in Lochner v. New York. ${ }^{125}$ Long before that decision, Christopher Columbus Langdell advanced a vision that law could be made both perfectly formal and perfectly coherent. As Thomas C. Grey describes Langdell's orthodoxy, "law is a science; its materials are all in law books; behind the mass of those materials are a few simple principles; and discovery of those principles will allow us to "master the ever-tangled skein of human affairs." "26 This view, infused with a notion of evolution, fed the Lochner Court's vision that the judge was to construct a reasonable constitutional system in accordance with scientific governance. ${ }^{127}$ Once again, a broad inquiry based in fact would yield the coherent structure dictated by our national constitution. More than that, the elevation of science revived a brand of constitutional creativity similar to that associated with the Founding generation.

The demise of Lochner did not mark the demise of science in constitutional interpretation, nor the demise of the Enlightenment ideal. Both forces garnered criticism in the legal realist movement, which aspired to scientific understanding of the law but eschewed the notion that legal interpretation pursued first principles, factual accuracy, or structural coherence. ${ }^{128}$ Although the Court rejected Lochner's brand of science in the New Deal cases, it continued to accept a role for a different brand of science for discerning public values. As Justice Jackson put it in West Virginia Board of Education v. Barnette, the New Deal Court inhabited a world that had replaced the laissez faire

125 Lochner v. New York, 198 U.S. 45 (1905).

126 Thomas C. Grey, Langdell's Orthodoxy, 45 U. PITT. L. Rev. 1, 51-52 (1983) (quoting C.C. Langdell, A SELECTION OF CASES On THE LAW OF CONTRACTS, at vii-ix (Bos., Little, Brown \& Co., 2d ed. 1879)).

127 For a discussion of Lochner in the frame of scientific governance, see KAHN, supra note 102 , at $97-117$.

128 Of course, the legal realist label has long been contested and of uncertain descriptive value. See Brian Z. Tamanaha, Understanding Legal Realism, 87 TEX. L. Rev. 731, 735-38 (2009) (describing disputes among early legal realists about the meaning of the realist label). The two strands mentioned here can be illustrated with reference to two of the most prominent realists. Jerome Frank famously applied the tenets of psychoanalysis to law, arguing that we must eliminate the delusions produced by our collective search for a father figure in the law and instead question "not hastily, angrily, rebelliously, but calmly and dispassionately-our bequests from the past, our social heritage." JEROME FRANK, LAW AND THE MODERN MIND 245 (1930). Whereas Frank condemned the delusions produced by our pursuit of a father figure in the law, Thurman Arnold defended both the delusions of law and the incoherence they obscured. See Thurman W. ARnOLD, The SyMBOLS OF GOVERNMENT 44 (1935) ("It is child's play for the realist to show that law is not what it pretends to be .... Yet the legal realist falls into grave error when he believes this to be a defect in the law."). 
"principle of non-interference" with principles demanding "closer integration of society" and "governmental controls." In reaching that conclusion, the Court drew on principle: Lochner, it argued, had contravened the "principles" demanded by the Commerce Clause. ${ }^{130}$ By returning to first principles, the Court purported to right the ship.

For constitutional theorists, the task of the post-New Deal era lay in legitimating that reversal within a coherent constitutional framework. The Court's decision in Brown made it difficult to tell a story of simple repudiation-what was the scope of the judicial power? Once again, theorists labored to discern the dictates of our constitutional body. In his 1958 Holmes Lectures, Learned Hand returned to Marbury only to find the decision more expansive than the constitutional text. Accordingly, he devised a theory of judicial review rooted in political theory. ${ }^{131}$ A year later, Herbert Wechsler employed a similar approach to reach a different result. Wechsler's claim that judicial review can only be legitimate when it is "entirely principled" echoes the voices of Enlightenment present at the Founding. ${ }^{132}$ Interpretation, for Wechsler, demanded an unwavering commitment to first principles: we must parse each issue in each case and arrive at a result that would apply across the broader constitutional universe. ${ }^{133}$

In these debates, the Enlightenment ideal served as a litmus test for proposed theories. Like Hand and Wechsler, Alexander Bickel advanced a theory of judicial review that promised "principled adjudications." 134 Bickel's path to principle, however, left his theory more of a scholarly foil than an accepted account of constitutional meaning. Scholars rejected Bickel's claim that "[n]o good society can be unprincipled; and no viable society can be principle-ridden." ${ }^{135}$ They derided the obscurantism and contradiction seemingly allowed by Bickel's notion of prudence. ${ }^{136}$ Instead, theorists gravitated toward

129 W. Va. State Bd. of Educ. v. Barnette, 319 U.S. 624, 640 (1943).

130 See, e.g., United States v. Darby, 312 U.S. 100, 116-17 (1941) ("The conclusion is inescapable that Hammer $v$. Dagenhart, was a departure from the principles which have prevailed in the interpretation of the Commerce Clause both before and since the decision ... [and] should be and now is overruled.").

136 Perhaps most notably, see Gerald Gunther, The Subtle Vices of the "Passive Virtues"-A Comment on Principle and Expediency in Judicial Review, 64 COLUM. L. REV. 1, 10 (1964) ("One watches with fascination as Bickel walks his tightrope, as he manipulates his nonprincipled techniques of accommodation to preserve a precarious balance."). More generally, see Anthony T. Kronman, Alexander Bickel's Philosophy of Prudence, 94 YALE. L.J. 1567, 1606- 
theories more transparently committed to Enlightenment. Accordingly, John Hart Ely's process-based theory has had more staying power than Bickel's. Ely's theory of judicial review claims consistency with principle, historical fact, and a broad constitutional coherence. ${ }^{137}$

Prominent competing theories exhibit an even more overt concern with coherence and factual accuracy in constitutional interpretation. Consider two such theories: Bruce Ackerman's theory of dualist democracy and Frank Michelman's theory of civic republicanism. For Ackerman, constitutional history reveals a constitutional order rooted in extra-textual amendment and intergenerational synthesis. If only we look, he claims, a coherent system of principled meaning emerges. In essence, Ackerman strikes the same pose as the Framers: He surveys our collective history to capture the coherent constitutional system it must contain. ${ }^{138}$ For Michelman, the essence of our constitutional system lies in inquiries like Ackerman's. In the notion of civic republicanism, Michelman endeavors to place such inquiry at the core of the task of nine justices of the Supreme Court. There, through dialogue, Michelman envisions a project of constitutional discovery much like that undertaken by the Framers. ${ }^{139}$ In these two theories, and others, the rhetoric of Enlightenment lives on.

\section{Mythology, Disjunction, and Enlightenment}

As the preceding Parts should make clear, a dominant constitutive myth of our constitutional order decries mythology and disjunction. The Enlightenment ideal refuses to distinguish between constitutive mythology and objective falsehood, and it refuses to allow objective falsehood to influence constructions of constitutional meaning. That

08 (1985) (describing the rise of a "rationalist spirit" that has rendered Bickel's notion of prudence "an embarrassed virtue in a discipline that has always been hospitable to it").

137 JOHN HART Ely, DEMOCRACY AND Distrust: A THEORY OF JUDICIAL REVIEW 101-04 (1980) (asserting that conceiving of judicial review as a mechanism to police political representation is consistent with past constitutional practice and constitutional coherence in a manner that prevailing interpretive modes are not).

138 Notably, the coherent constitutional meaning Ackerman discerns places contemporary Americans in the same position as the Framers. For Ackerman, "[i]t is only by talking together about the deepest values of dualist democracy that we can reflect on the best ways to continue the ongoing American engagement with higher lawmaking." 1 ACKERMAN, supra note 31 , at 57 .

139 Michelman, supra note 54; see also Frank Michelman, Law's Republic, 97 YALE L.J. 1493, 1524-32 (1988) (arguing that a civic republican view of constitutionalism legitimates judicial review because it helps "make credible for contemporary Americans the idea of social and procedural conditions under which communicative revision of a citizen's normative understandings escapes condemnation as oppression" and because it enables the "plurality on which [our] capacity for transformative self-renewal depends"). 
is, there is no such thing as a desirable falsehood or a desirable inconsistency. When we develop a theory of constitutional interpretation, these are the ground rules. Like so many constitutive myths, however, the Enlightenment ideal does not marshal a vigorous argument for its own justification. Defenders invoke concerns about popular sovereignty and political morality. Yet they do not offer much of a response to scholars who have advanced visions of reason that call for departures from constitutional truth.

Take criticism of legal fictions. First, scholars attack the legal fiction's distortion of reality as a threat to appropriate constructions of the law. The law may accept the distortion, but this does not eliminate the false premise. ${ }^{140}$ Second, scholars contend that fictions produce obscurantism and confusion about the law. Falsehoods draw our attention away from factors animating legal decisions and they introduce complication into the legal fabric. ${ }^{141}$ Third, scholars charge legal fictions with bringing the law into disrepute for its endorsement of patent falsehoods. A single visible falsehood, by this view, may harm the institution of legal ordering. ${ }^{142}$ These three criticisms do little more than parrot Enlightenment conclusions. Fictions distort the law because our view of the law disallows them. Fictions confuse because we do not theorize about them. Fictions sully the law's reputation because we construct a reputation that eschews fictions.

Criticism of legal myth evokes a similarly conclusory flavor. Scholars attack legal myth on two primary grounds. First, legal myth inhibits our ability to reason to first principles. Suppose that no person recognizes the falsehood of a particular premise. The legal myth preserves that false premise and accordingly produces mistaken conclusions. ${ }^{143}$ Second, legal myth inhibits democratic processes. Suppose that a few people recognize the falsehood of a particular prem-

140 This critique is so omnipresent it hardly needs detailing. For a colorful statement, see Jeremy Bentham, Scotch Reform, in 5 THE WORKS OF JEREMY BENTHAM 1, 13 (John Bowring ed., 1962) (defining legal fiction as a "willful falsehood, uttered by a judge, for the purpose of giving to injustice the colour of justice").

141 See, e.g., MAINE, supra note 18, at 26 (arguing that "it is unworthy of us to effect an admittedly beneficial object by so rude a device as the legal fiction" because the legal fiction "makes the law either more difficult to understand or harder to arrange in harmonious order").

142 Although Roscoe Pound would later become more accepting of the legal fiction, his initial work criticized it largely for this reason. See, e.g., Roscoe Pound, Spurious Interpretation, 7 Colum. L. Rev. 379, 384 (1907) ("[I]n a modern state, spurious interpretation of statutes, and especially constitutions, tends to bring law into disrepute.”).

143 This is one of the most common strands within the law review genre; the author exposes a supposed myth and then charts the course to rectify the consequences of that myth. See, e.g., Ely, supra note 27 (conducting such an analysis of the Erie doctrine). 
ise, but most do not. Those left in the dark would be subject to the whims of those aware of the light. In a purely functional sense, this state of affairs pushes popular dialogue away from prevailing views of democracy. ${ }^{144}$ In a more philosophical sense, it threatens to impinge on concerns with equality, transparency, dignity, and the like. ${ }^{145}$ These assaults on legal myth, however, seldom occupy the legal scholar. For her, their conclusions are simply assumed.

Scholars have not advanced much additional justification for their condemnation of disjunction. In essence, they argue that falsehood obscures genuine legal meaning. As Karl Llewellyn argued, "[a] theory which suffers from any such misrepresentation of the facts confuses and distorts issues. It cannot help but lead, repeatedly, to purblind action." ${ }^{146}$ Such action, Llewellyn argues, "even when it is informed by considerable intuition, registers an unfortunate number of misses on occasions when bull's-eyes are needed."147 Of course, if a constitutional theory provided a place for legal fiction and legal myth, they could be accommodated without rendering disjunction. A theory that accepted all legal fictions and legal myths would be no theory at all, but a theory that allowed some would merely be a theory contrary to the Enlightenment ideal. ${ }^{148}$ Attacks on disjunction rarely endeavor to criticize such theories-or, indeed, to acknowledge their possibility.

This omission flies in the face of a small but substantial group of scholars that has advanced affirmative arguments for mythology and disjunction. These arguments have taken two forms. One group of scholars has questioned the internal consistency of the Enlightenment ideal. For these scholars, the Enlightenment ideal represents another legal fiction if not a legal myth. Accordingly, they have suggested that we eschew the ideal and recognize our acceptance of mythology and disjunction. Another group has defended mythology and disjunction despite their contravention of the Enlightenment

144 This line of criticism is one motivating force behind Bruce Ackerman's effort to expose the process of extratextual amendment. Only with prevailing myths exposed, the argument goes, can our constitutional system function in accordance with popular will. See 1 ACKERMAN, supra note 31, at 3-6 (describing the "reconstructive enterprise" interpretation of the Constitution).

145 For example, John Rawls argues that publicity must be a condition for reaching a concept of right. JOHN RAWLS, A THEORY OF JUSTICE 130 \& n.5 (1971).

146 K.N. Llewellyn, The Constitution as an Institution, 34 CoLum. L. REV. 1, 2-3 (1934) (footnote omitted).

147 Id. at 3.

148 That is, a theory that accepted all legal fictions and legal myths would accept any falsehood, and thus would fail to meaningfully differentiate any two systems of meaning. 
ideal. These scholars reject the Enlightenment ideal as a suboptimal constitutional principle, not because it fails to satisfy its own principles. They contend that some deftly introduced mythology and disjunction may assist our constitutional order.

Consider, first, scholarly efforts to expose the internal contradictions of the Enlightenment ideal. The Enlightenment ideal, according to scholars of this view, is no more foundational than any other system of social meaning. Theodor Adorno and Max Horkheimer's classic treatment of the Enlightenment puts the point nicely. "In the enlightened world," they write, "mythology has entered into the profane. In its blank purity, the reality which has been cleansed of demons and their conceptual descendents assumes the numinous character which the ancient world attributed to demons." ${ }^{149}$ The particular brand of reason advanced by Enlightenment thought, they argue, inevitably collapses upon itself. That is, the Enlightenment ideal is itself a product of mythology and devolves into the transparent falsehood Adorno and Horkheimer perceived in European fascism. $^{150}$

Legal scholars have extended this notion to the Enlightenment's influence on our visions of the Constitution. Echoing calls among the legal realists, Max Lerner argued that "[e]very tribe needs its totem and its fetish, and the Constitution is ours." constitutional reverence produced a vision of judges not as "ordinary men, subject to ordinary passions, but 'discoverers' of final truth, priests in the service of a godhead." ${ }^{152}$ A similar view prompted Sanford Levinson, years hence, to warn that " $[\mathrm{t}]$ he "death of constitutionalism' may be the central event of our time just as the 'death of God' was that of the past century (and for much the same reason)." The Enlightenment ideal, in this sense, sows the seeds of its own destruction.

A few scholars have taken up Levinson's warning and embraced the possibility of the death of constitutionalism. Steven D. Smith has argued that given the "labyrinthine emptiness" that characterizes

149 Theodor W. Adorno \& Max Horkheimer, Dialectic of Enlightenment 28 (John Cumming trans., 1997).

150 See, e.g., id. at 194 ("True madness lies primarily in immutability, in the inability of the thought to participate in the negativity in which thought-in contradistinction to fixed judgment—comes into its own. The paranoiac insistence on rationality, the poor infinity of an unchanging judgment, reveals a lack of sequacious thought.").

151 Max Lerner, Constitution and Court as Symbols, 46 YALE L.J. 1290, 1294 (1937).

152 Id. at 1312.

153 Sanford Levinson, "The Constitution" in American Civil Religion, 1979 SUP. CT. REV. 123, 151. 
constitutional interpretation, ${ }^{154}$ it may be true that "reason teaches the futility of trying to live in accordance with reason." ${ }^{155}$ Pierre Schlag has been less equivocal. He argues that reason inevitably devolves into a dogmatic force that serves the law's will rather than any foundational set of principles. Reason becomes the excuse to construct "endless legal mazes" rather than a force that deepens understanding. "When reason runs out, but continues to rule," Schlag argues, "we get precisely what we see all around us-the excessive construction of a pervasively shallow form of life." 157 For these scholars, the way out lies in replacing dogma with genuine engagement.

These arguments, however, have garnered little sustained response from adherents of the Enlightenment ideal. They have occupied the fringes of the Legal Realist and Critical Legal Studies Movements, and they have been rejected more as inconvenient than incorrect. In this sense, Owen Fiss spoke for an entire legal orthodoxy when he rejected the view that we cannot reason to objective constitutional meaning: "It must be combated and can be, though perhaps only by affirming the truth which is being denied...."158 There is not much debate about the merits of reason, much less Enlightenment reason. The conclusion is assumed, and contrarians merely contrarians. ${ }^{159}$

Consider, next, scholarly efforts to defend the introduction of mythology and disjunction in legal interpretation. Scholars have defended legal fictions as tools of both expediency and coherence. Blackstone argued that so long as the law follows the maxim that "no fiction should extend to work an injury," fictions would be "highly beneficial and useful" as a means to "prevent a mischief, or remedy an inconvenience, that might result from the general rule of law." John Chipman Gray expressed doubts about the potential legal distortions that might arise from remedies of this sort, but he defended legal fictions that organize the structure of the law. ${ }^{161}$ Perhaps most

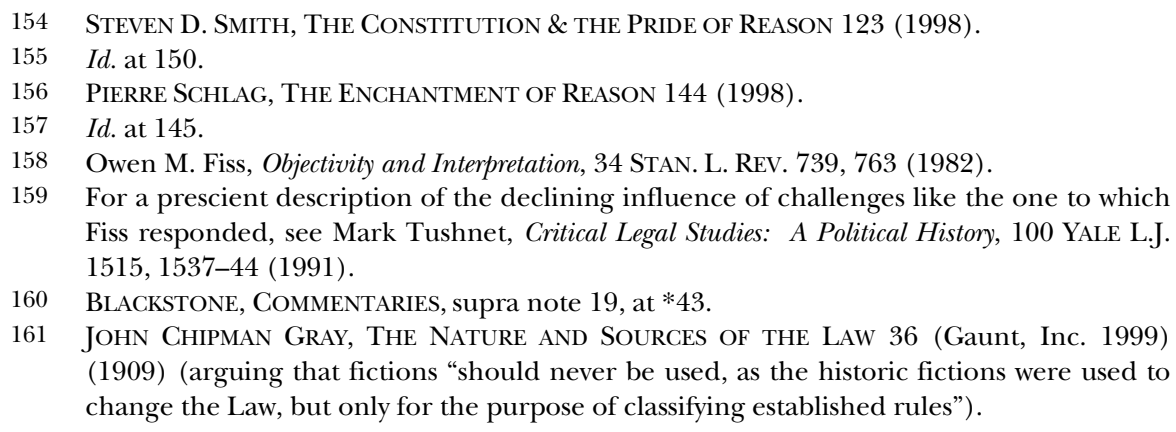


prominently, Lon Fuller combined these strands, arguing that legal fictions allow us "to plaster together the weak spots in our intellectual structure." 162 There have not been comparably systematic defenses for legal fiction in the constitutional realm, but occasional defenses of individual fictions evoke the same two concerns. ${ }^{163}$ Active defenses of constitutional fictions, however, are rare.

Defenses of legal myths take two similar tacks. First, scholars argue that legal myths may help improve substantive outcomes in a utilitarian sense. Meir Dan-Cohen, for example, has defended an "acoustic separation" between rules applied by judges and rules perceived by the public. ${ }^{164}$ Such a separation, Dan-Cohen argues, may help improve compliance with criminal law. ${ }^{165}$ Second, scholars argue that legal myths allow us to diffuse the destructive consequences of choices between irreconcilable values. This view is most associated with Guido Calabresi and Philip Bobbit's analysis of tragic choices, ${ }^{166}$ though it has a longer history in American law. ${ }^{167}$ Scholars of this bent have argued that although we should presume in favor of candor, candor may undermine confidence in the law. Although neither of these arguments has singled out the constitutional realm, they apply there with as much force as in the common law or statutory contexts.

Beneath these defenses of legal fiction and legal myth lie defenses of disjunction. Of course, an interpretive theory might demand certain legal fictions and legal myths. In such case, the presence of those fictions and myths would signal conjunction rather than disjunction. The defenses just enumerated, however, seek to justify departures from theory rather than to justify falsehood within theory. They excuse departures from a broader theory of interpretation. The

162 FULLER, supra note 17 , at 52.

163 For example, David Currie described the rule in Ex Parte Young as based on an "outlandish conceptual justification" and yet argued that "[b]ehind the outlandish conceptual justification concocted to support this holding lay the not implausible conviction that federal constitutional rights could not be adequately protected without the intervention of federal equity; therefore the philosophy of immunity had to yield." David P. Currie, The Three-Judge District Court in Constitutional Litigation, 32 U. CHI. L. REv. 1, 4 (1964).

164 Meir Dan-Cohen, Decision Rules and Conduct Rules: On Acoustic Separation in Criminal Law, 97 HARV. L. REV. 625, 630 (1984).

$165 I d$. at 668 (arguing that "the clarity and specificity of decision rules, and hence their effectiveness as guidelines, may be enhanced by the use of a technical, esoteric terminology that is incomprehensible to the public at large").

166 See generally Guido Calabresi \& Philip Bobbitt, Tragic ChOICES (1978).

167 See, e.g., ARNOLD, supra note 128, at 247-48 (arguing that the "greatness of law" lies in its creation of an "appearance of unity while tolerating and enforcing ideals which run in all sorts of opposing directions," which "provides a way of talking about all the unsolved and unsolvable problems of society"). 
legal fiction circumvents the dictates of an interpretive theory for the sake of some combination of expedience and coherence. The legal myth obscures departures from an interpretive theory for similar reasons. A theory cannot develop an account of its legitimate circumvention; this would merely alter the content of the range of actions legitimated by the theory. Prevailing defenses of legal fiction and legal myth, then, defend more than just falsehood; they defend disjunction.

Once again, proponents of the Enlightenment ideal have not responded with much more than condemnation. Defenses of legal fiction have not been met with much more than the claim that falsehood anywhere is a threat to constitutionalism everywhere. ${ }^{168}$ In these assertions, rhetoric runs thick; the refrain echoes Bentham's quip that fiction constitutes "a syphilis" in the law. ${ }^{169}$ Defenses of legal myth have been met with much the same. David L. Shapiro sums up the prevailing view that no scholar has rebutted the presumption for judicial candor in any significant way. ${ }^{170}$ Although Dan-Cohen and Calabresi's arguments against candor garnered much scholarly interest, they have not garnered many followers. Given the condemnation of both legal fiction and legal myth, disjunction has not received any sustained attention.

\section{THE COMMON LAW CULTURE}

Our constitutional order may have been born in a time of Enlightenment, but it emerged within a common law culture. The Framers and their successors did not eschew that culture; rather, they enshrined it in our constitutional processes and our constitutional discourse. Whereas the Enlightenment tradition invokes a notion of reason as the key to an ordered universe, the common law culture invokes the stabilizing power of tradition. The common law culture calls upon the judge to reason, but not in an Enlightenment sense. Permissible judicial inquiry occupies boundaries shaped by past experience. As this Part demonstrates, the judicial inquiry demanded by

168 For a more searching recent analysis, see generally Smith, supra note 26 (analyzing "new legal fictions" and arguing that their benefits are outweighed by the presumption in favor of judicial candor.

169 Jeremy Bentham, The Elements of the Art of Packing, in 5 The Works of Jeremy BENTHAM, supra note 21, at 92.

170 See David L. Shapiro, In Defense of Judicial Candor, 100 HARv. L. REv. 731 (1987). Shapiro only finds the case against candor compelling when (1) a judge faces a conflict between a legal and moral right, (2) the judge decides he has a moral duty to support the moral right, and (3) resignation will not fulfill the judge's moral duty. Id. at 749-50. 
the common law culture self-consciously allows for mythology and disjunction in constitutionalism.

This Part explores five elements of our constitutional system that arose out of the common law: justiciability doctrine, stare decisis, the rule against retroactivity, the distinction between holding and dicta, and the practice of writing separately. The first three elements preserve false constructions of constitutional meaning. Justiciability prevents courts from assessing mythology and disjunction that arises beyond a particular type of controversy. Stare decisis does not allow courts to correct mythology and disjunction even when it is properly before them. Retroactivity doctrine forbids courts from redressing past decisions built on foundations of mythology and disjunction. The last two elements-dicta and writing separately-expose these realities for all to see.

\section{A. Justiciability}

Justiciability doctrine arising under the language about "cases" or "controversies" in Article III has long been condemned as incoherent and unprincipled. ${ }^{171}$ Much of it has been cast as the product of judicial invention. ${ }^{172}$ This is quite understandable. It does not take much effort to notice the wealth of meaning courts have imparted onto Article III's Delphic notion of the "judicial Power." tion captured by justiciability lend itself to a clearly defined set of rules or standards. Efforts to justify this body of doctrine, nonetheless, often turn to the understanding of the Framers. ${ }^{174}$ These efforts invariably invoke the prevailing vision of the judiciary at common law. The notion of justiciability, though not explicit in common law courts, grasps at the private-law judicial function embodied in those courts. ${ }^{175}$

171 See U.S. CONST. art. III, § 2. For a recent articulation of this line of criticism, see Jonathan R. Siegel, A Theory of Justiciability, 86 TEx. L. REv. 73, 74-75 (2007).

172 See, e.g., John A. Ferejohn \& Larry D. Kramer, Independent Judges, Dependent Judiciary: Institutionalizing Judicial Restraint, 77 N.Y.U. L. REv. 962, 1004 (2002) (“[N]o one seriously believes that the Framers chose [the words of Article III, Section 2] with anything like the Supreme Court's doctrinal framework in mind or that the Court's justiciability rulings are anything other than a judicially invented gloss on the Constitution.”).

173 U.S. CONST. art. III, § 2.

174 See, e.g., Ann Woolhandler \& Caleb Nelson, Does History Defeat Standing Doctrine?, 102 MiCH. L. REv. 689, 691 (2004) (arguing that "history does not defeat standing doctrine; the notion of standing is not an innovation, and its constitutionalization does not contradict a settled historical consensus about the Constitution's meaning" (emphasis omitted)).

175 For a statement to this effect, see, for example, Honig v. Doe, 484 U.S. 305, 340 (1988) (Scalia, J., dissenting) (arguing that the case or controversy requirement has "virtually no 
This is not to say that modern justiciability doctrine enshrines the particularities of the judicial role at common law. Modern views of justiciability echo elements of the English system in some respects but not in others. The constitutional prohibition on advisory opinions, for example, has been settled law since the first years of the Republic, but no such prohibition existed at common law. ${ }^{176}$ In refusing to issue an advisory opinion at the request of George Washington, the Court invoked the Constitution's separation of powers. ${ }^{177}$ Modern supporters of this conclusion have bolstered it with structural arguments. ${ }^{178}$ To take another example, scholars largely agree that modern standing doctrine creates limitations that were not present at common law. ${ }^{179}$

Justiciability doctrines with common law roots, however, promote common law notions of litigation and adjudication. Consider, for example, the requirement of adverse parties. Although the Court has reached the merits of some collusive cases ${ }^{180}$ it has read Article III's "case" or "controversy" requirement to preclude such cases. ${ }^{181}$ In so doing, the Court has cast the judicial power in the common law mold: it is the power to resolve disputes in an adversarial process. Common law courts may have entertained advisory opinions for the Crown, but they did not entertain them for private parties. In its relation to private parties, the judicial role did not extend to abstract interpretive inquiries; rather, it extended to the resolution of genuine disputes. $^{182}$

meaning" except by reference "to the traditional, fundamental limitations upon the powers of common law courts").

176 See Stewart Jay, Most Humble Servants: The Advisory Role of Early Judges 57-76 (1997).

177 Id. at $179-80$.

178 See, e.g., Akhil Reed Amar, Some Opinions on the Opinion Clause, 82 VA. L. REv. 647, 647 (1996) (arguing that the Framers designed the Opinion Clause "to clarify the role of a new and distinctly American idea of a President, who would be measurably less than an English-style King, but measurably more than an English-style Prime Minister").

179 See Woolhandler \& Nelson, supra note 174, at 690 (recognizing that this is a "widely accepted academic critique[]"). For a prominent exposition of this critique, see Raoul Berger, Standing to Sue in Public Actions: Is It a Constitutional Requirement?, 78 YALE L.J. 816, 818 (1969) (arguing that standing is "a judicial construct pure and simple which ... is of relatively recent origin").

180 See e.g., Pennington v. Coxe, 6 U.S. (2 Cranch) 33, 33-34 (1804) (reaching "a feigned issue").

181 See e.g., United States v. Johnson, 319 U.S. 302, 305 (1943).

182 This story of the judicial role, of course, does not adequately account for the rise of public law. See, e.g., Abram Chayes, The Role of the Judge in Public Law Litigation, 89 HARV. L. REv. 1281, 1284 (1976) (describing the characteristic attributes of public law litigation's party relationships and judicial role as compared with the American legal system's "traditional model" of litigation). 
The judicial role might look quite different. We might allow courts to engage in legal interpretation absent a genuine dispute. For the common law lawyer, the particular facts of the dispute before the court make the inquiry into law possible. It is not merely that facts allow the judge to engage the intricacies of the law; the zealous advocacy of adverse parties served to ensure the accuracy of that engagement. ${ }^{183}$ Civil-law systems, of course, provide a more limited place for zealous advocacy in a process dominated by judicial inquiry. The judicial task turns more on inquiring into facts than discerning law provided by statute. ${ }^{184}$ Some constitutional courts, moreover, allow for inquiries into constitutional questions before they arise in an individualized dispute. ${ }^{185}$

Modern defenses of justiciability doctrine invoke two broad arguments about the judicial role. First, justiciability requirements ensure that adjudication addresses concrete issues brought by zealous advocates. Second, justiciability requirements ensure that the courts do not overstep their bounds vis-à-vis the political branches. The former argument has roots in the common law notion of private rights. It contends that litigants should have a stake in a genuine dispute capable of judicial redress. ${ }^{186}$ The latter argument draws on both constitutional structure and the common law notion that courts interpret law rather than make it. This argument claims that courts should ensure that the judicial process is representative, passive, and divorced from politics. In essence, these defenses set forth a vision of both the subject matter and the scope of adjudication. ${ }^{187}$

This common law vision of adjudication accepts a role for mythology and disjunction. Return to the adverse-party requirement. The

183 For a discussion of the influence of the common law's adversarial process on the American legal system, see Robert A. KAGAN, AdVERSARIAl Legalism: THE AMERICAN WAY OF LAW 3-58 (2001) ("Many, perhaps most, American lawyers, judges, legal scholars, and politicians (many of whom are lawyers) see adversarial litigation as a vital tool for righting wrongs, curtailing governmental and corporate arbitrariness, and achieving a just society.").

184 See John Henry Merryman, The Civil Law Tradition: An Introduction to the Legal SYSTEMS OF WESTERn EUROPE AND LATIN AMERICA 37 (1969) (describing the civil-law judge as "a kind of expert clerk" who is "presented with a fact situation to which a ready legislative response will be readily found in all except the extraordinary case").

185 See Frederick Schauer, Do Cases Make Bad Law?, 73 U. CHI. L. Rev. 883, 914 (2006) (describing both foreign and state courts that engage in this practice).

186 In Baker v. Carr, for example, the Court explained that standing doctrine ensures that a party seeking relief has "alleged such a personal stake in the outcome of the controversy as to assure that concrete adverseness which sharpens the presentation of issues upon which the court so largely depends for illumination of difficult constitutional questions." 369 U.S. 186, 204 (1962).

187 For an overview and critique of these theories, see Siegel, supra note 171, at 90-120. 
notion that adverse parties preserve a bounded judicial role consistent with the separation of powers rings hollow; subject to standing requirements, private parties may contrive adverse cases to garner judicial review. ${ }^{188}$ The notion that adverse parties enhance the truthseeking function of the adjudicative process is more plausible. ${ }^{189}$ Such benefits, however, come at the expense of rendering the lawyer an agent of advocacy rather than accuracy. Adjudication becomes an obscurantist battle in which the parties, constrained by loose ethical requirements, often pursue misunderstanding of law and fact. Indeed, the victorious lawyer may celebrate a decision reliant on mythology and disjunction. ${ }^{190}$

Of course, the task of the judge is to thwart such efforts. We might accept the obscurantist tendencies of adversarial litigation if it nonetheless presents the best path to interpretive truth. Parties would advance mythology and disjunction, but the successful judge would root it out. Madison might argue that the adversity requirement serves the same purpose as the separation of powers: to channel inevitable self-interest into collective truth. ${ }^{191}$ A few duped judges, we might say, are well worth the broader benefits of the adversarial system. This story may fail to grapple adequately with the array of obscurantist tools available to the lawyer, but it is nonetheless plausible. ${ }^{192}$ Justiciability doctrines like standing, ripeness, and mootness, by contrast, take a more unequivocally permissive view of mythology and disjunction. es for the specific purpose of getting courts to resolve legal issues and to compel the government to obey the laws.").

189 For a defense of the adversarial system along these lines, see Lon L. Fuller, The Forms and Limits of Adjudication, 92 HARV. L. REV. 353, 384 (1978) (“[T] he role of the lawyer as a partisan advocate appears not as a regrettable necessity, but as an indispensable part of a larger ordering of affairs. The institution of advocacy is not a concession to the frailties of human nature, but an expression of human insight in the design of a social framework within which man's capacity for impartial judgment can attain its fullest realization."). See generally Stephan LandSMAn, The AdVERSARy System: A Description and DEFENSE (1984).

190 See Marvin E. Frankel, The Search for Truth: An Umpireal View, 123 U. PA. L. Rev. 1031, 1039 (1975) ("[T]he gladiator using the weapons in the courtroom is not primarily crusading after truth, but seeking to win").

191 That is, we might think of Madison's call that “[a]mbition must be made to counteract ambition" as a generalization of this mode of common law adjudication. THE FEDERALIST No. 51, at 347 (James Madison) (Heritage Press 1945).

192 As Frankel notes, for example, the rules of professional responsibility only proscribe positive frauds; they do not compel disclosures of material facts or forbid material omissions. Frankel, supra note 190, at 1057-58 (arguing that the rules of professional responsibility should compel a lawyer to disclose material facts, and should forbid a lawyer from making material omissions unless he or she is prevented by privilege). 
Let us focus on standing. Since the formal emergence of standing doctrine after the New Deal, scholars have disputed its origins at common law. Invoking mandamus practice and qui tam statutes that preceded the Founding, a vocal group of scholars have sought to cast doubt on the constitutional basis for the doctrine. ${ }^{193}$ These scholars have cast the doctrine as a fiction invented by Justice Frankfurter and Justice Brandeis. ${ }^{194}$ Another set of scholars has set out to defend the constitutional basis for standing doctrine by identifying the concept of standing, if not the term itself, in the common law's distinction between public and private rights. These scholars argue that private actions to protect public rights were rare at common law, if present at all. ${ }^{195}$ Nonetheless, the concept of standing evokes the private-law orientation present at common law.

Defenses of the concept of standing appeal to each of the arguments advanced in defense of justiciability doctrine more broadly. Although the contours of the doctrine are much disputed and maligned, scholars often contend that standing doctrine ensures zealous advocacy and constrains judicial overstep. ${ }^{196}$ These arguments are seldom contested in the realm of private harms like tort. To confer standing on parties not privy to the harm would impose additional costs on harmed parties who choose not to seek redress in court. ${ }^{197}$ In the realm of public rights, however, the arguments are more controversial. Parties who do not meet standing requirements may engage in less zealous advocacy than would parties who do. ${ }^{198}$ Moreover, standing requirements hardly prevent courts from ruling on issues of great social importance.

Standing doctrine promotes mythology and disjunction in at least two ways. First, standing doctrine's vague requirements of injury in

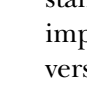
impartial results. Injured parties are likely to pursue their claims vigorously and the adversary process enables courts to uncover all the relevant facts and issues necessary to reach the best and most fair outcomes.”).

197 That is, parties who did not wish to litigate their claims could be called upon to participate in aspects of the litigation seeking to vindicate those claims.

198 See Maxwell L. Stearns, Standing Back from the Forest: Justiciability and Social Choice, 83 CALIF. L. REV. 1309, 1409 (1995) ("While the Court has stated, for example, that standing is designed to promote zealous advocacy, it has denied standing to the unquestionably zealous Sierra Club.”). 
fact, causation, and redressability allow judicial obscurantism and evasion. That is, courts may cloak the real grounds for their decisions in considerations about standing. ${ }^{199}$ In so doing, courts introduce falsehood into the stream of the law. Second, standing doctrine prevents courts from reaching the merits of disputes, particularly those involving diffuse public rights. In controversies that implicate constitutional questions, this allows mythology and disjunction to persist apart from judicial inquiry. The result is not only non-enforcement; it is non-interpretation. ${ }^{200}$ In tandem, these two forces prompt courts to both contribute misunderstanding to the law and preserve that misunderstanding.

Many scholars have expressed concern about standing doctrine's relationship with both obscurantism and non-enforcement. ${ }^{201}$ Fewer have expressed concerns about its relationship with substantive constitutional interpretation. The cardinal interpretive sin in our legal order is to reach constitutional issues unnecessary for the disposition of the case at bar. It is to such actions that the oft-repeated charge of "judicial activism" perhaps best applies. ${ }^{202}$ The canon of constitutional avoidance formalizes this view: we should be wary about deciding constitutional issues lest we get them wrong. Presumptions against interpretation call upon courts to preserve prevailing views of constitutional truth without interrogating them. There may be good reasons for such presumptions; in the short term, they produce consistency and stability. ${ }^{203}$ In the long term, however, they allow falsehood and infidelity in constitutional interpretation.

Concerns about reaching constitutional questions unnecessary to the case at hand occupy the shadow of the common law doctrine of stare decisis. To misconstrue the Constitution would not only do in-

199 As Abram Chayes famously put this charge, the Court engages in a "ritual recitation" of the requirements for standing and then "chooses up sides and decides the case." Abram Chayes, The Supreme Court 1981 Term-Foreword: Public Law Litigation and the Burger Court, 96 HARV. L. REV. 4, 23 (1982).

200 This is the same result as another feature of common law adjudication: settlement. See Owen M. Fiss, Comment, Against Settlement, 93 YaLE L.J. 1073, 1085-87 (1984).

201 See Steven L. Winter, The Metaphor of Standing and the Problem of Self-Governance, 40 STAN. L. REV. 1371, 1373 n.14 (1988) ("Although it is probably impossible to document, I suspect that most academics and practicing lawyers at least share the suspicion that standing law is nothing more than a manipulation by the Court to decide cases while not appearing to decide their merits.").

202 For a discussion of how best to apply the term "judicial activism," see Craig Green, $A n$ Intellectual History of Judicial Activism, 58 EMORY L.J. 1195, 1199 (2009) (arguing that this "label is useful only where a judge has violated cultural standards of judicial role").

203 For a defense of the constitutional avoidance canon, see, for example, BICKEL, supra note 53, at 181-83; Ernest A. Young, Constitutional Avoidance, Resistance Norms, and the Preservation of Judicial Review, 78 TEX. L. REV. 1549, 1552 (2000). 
justice in the present case; it would wreak havoc on future cases. I will turn to stare decisis momentarily. Before I do, however, it is worth noting that both mootness doctrine and ripeness doctrine present the same possibility of mythology and disjunction as standing doctrine. Each doctrine provides an avenue for judicial obscurantism and prevents interrogation of prevailing constitutional interpretations. Justiciability doctrine, then, advances mythology and disjunction in two ways. First, it promotes obfuscation by parties and courts. Second, it preserves the interpretive status quo regardless of its relationship with constitutional truth.

\section{B. Stare Decisis}

Like so many central phrases of our constitutional discourse, "stare decisis" does not appear in the text of the Constitution. Its textual mooring, moreover, is arguably more tenuous than that of justiciability doctrine. ${ }^{204}$ While scholars have defended the concept of justiciability with respect to the separation of powers, stare decisis represents a doctrine more purely contained in judicial process. So long as the political branches may rely on a consistent judicial view of precedent, it is difficult to argue that the structure of the constitutional text mandates one view of stare decisis or another. The textual basis for stare decisis, if there is one at all, must be found in the Founding vision of the "judicial Power" provided by Article III. That is not to say that this basis is a stretch; stare decisis occupied the core of the common law tradition inherited by the Framers. ${ }^{20.5}$

As it has evolved, the American notion of stare decisis has taken on a familiar set of conceptual divisions. Courts distinguish between three levels of stare decisis: common law stare decisis, statutory stare decisis, and constitutional stare decisis. At common law, precedent garners heavy deference, whereas decisions on statutory and constitutional grounds garner successively less. ${ }^{206}$ Repetition of this hierarchy

204 See Henry Paul Monaghan, Stare Decisis and Constitutional Adjudication, 88 COLum. L. REV. 723, 754-55 (1988) (discussing the uncertain constitutional source of stare decisis).

205 The intent of the Framers on this point, perhaps unsurprisingly, is a rich area for scholarly debate. Compare Michael Stokes Paulson, Abrogating Stare Decisis by Statute: May Congress Remove the Precedential Effect of Roe and Casey?, 109 YaLE L.J. 1535, 1550 (2000) (arguing that the Constitution does not require that the Court accord decision-altering weight to prior judicial precedent), with Richard H. Fallon, Jr., Stare Decisis and the Constitution: An Essay on Constitutional Methodology, 76 N.Y.U. L. REv. 570, 579-80 (2001) (arguing that the Framers understood "the judicial Power" to "include a power to create precedents of some degree of binding force" (internal quotation marks omitted)).

206 For a clear statement of the "three-tiered hierarchy" of stare decisis the Court follows, see William N. Eskridge, Jr., Overruling Statutory Precedents, 76 GEO. L.J. 1361, 1362 (1988). 
evades the more difficult conceptual question: how should we think of the form of deference afforded by stare decisis? Courts often invoke stare decisis to bolster independent conclusions on the merits. It is difficult to cast such pronouncements as instances of deference. Courts that make such decisions would have ruled the same way even in the absence of the prior decisions. They are in no sense bound by precedent; rather, they invoke it in solidarity. ${ }^{207}$

The deference captured by the notion of stare decisis requires something more. As Max Radin describes it, "the rule of stare decisis is evidently and demonstrably being maintained only when the court declares that the conclusion to which the rule constrains it is one which it would not have reached except for the rule." ${ }^{208}$ As examples, Radin refers to conclusions "of which the court does not morally approve, which cannot be rested on conscience, equity or the public welfare." ${ }^{209}$ In the language of mythology and disjunction, the court may feel confined to perpetuate a disjunction rooted in mistaken visions of history, morality, or practice. Radin's formulation leaves out a broader class of cases that rely on stare decisis even if they do not say so expressly: cases in which courts refuse to reopen questions that have already been decided. Such questions occupy much of the constitutional landscape as settled law. ${ }^{210}$

It goes without saying that we could have a legal regime that eschewed such constraints. Stare decisis does not exist at civil law. The comparison need not suggest that eschewing stare decisis would necessarily remake our judiciary in the image of the civil-law judge. ${ }^{211}$ Indeed, a regime without stare decisis could expand the interpretive role of the judge. Unconfined by prior decisions, she could expound the true character of the law. Nor would abandoning stare decisis necessarily lead the judiciary to abandon history. Judges could still invoke prior decisions to legitimate their present constructions of the

207 For a recent example, see McDonald v. City of Chi., 561 U.S. 3025 (2010). In his opinion for the majority, Justice Alito grounded the Court's extension of District of Columbia v. Heller, 554 U.S. 570 (2008), in its adherence to the doctrine of stare decisis even though the composition of the majority in McDonald was the same as the composition of the majority in Heller two years before and the reasoning similar. McDonald, 561 U.S. at 3049-50.

208 Max Radin, Case Law and Stare Decisis: Concerning Präjudizienrecht in Amerika, 33 COLUM. L. Rev. 199, 201 (1933).

209 Id.

210 See Monaghan, supra note 204, at 744-46 (arguing that stare decisis has an agendalimiting function, whereby " $[\mathrm{m}]$ any constitutional issues are so far settled that they are simply off the agenda").

211 For a discussion of the role of stare decisis in civil-law regimes, see MITCHEL DE S.-O.-L'E. Lasser, Judicial Deliberations: A Comparative ANALysis of Judicial Transparency AND LEGITIMACY 54-55 (2004). 
law. In constitutional interpretation, moreover, the shifts in public understanding reflected in past decisions might assume interpretive significance, even if not binding significance. Past decisions would not convey a rule or result to be followed, but rather a historical indicia of perceived constitutional meaning. ${ }^{212}$

In some sense, we subscribe to stare decisis because we have always subscribed to stare decisis. Yet the doctrine draws fervent, if somewhat disjointed, theoretical defenses. These defenses rely on three primary rationales. ${ }^{213}$ First, scholars and courts advance a range of utilitarian arguments that stare decisis ensures the coherence, legitimacy, and stability of the law. It conserves judicial resources, protects reliance interests, aligns judicial inquiry with judicial competence, and the like. ${ }^{214}$ Second, scholars and courts advance a view rooted in fundamental fairness. By this view, equality requires that like cases are decided alike, not just in a given moment but also across time. To decide like cases alike, by whichever metric of likeness, does not merely advance predictability, it ensures that the legal system safeguards the right to equal treatment. ${ }^{215}$

The third defense of stare decisis relies on a more primal notion of the importance of history. Anthony Kronman has advanced this view in distinguishing philosophy and law. "We must respect the past," he argues, "because the world of culture that we inherit from it makes us who we are. The past is not something that we, as already constituted human beings, choose for one reason or another to respect; rather, it is such respect that establishes our humanity in the first place." ${ }^{216}$ Kronman's argument, however, seldom accompanies the other two in the literature. ${ }^{217}$ Kronman has a ready explanation: "the immense prestige that reason now enjoys in every department of

212 Id. at 55-56.

213 I borrow this division from Anthony T. Kronman, Precedent and Tradition, 99 YaLE L.J. 1029, 1036-43 (1990).

214 See Larry Alexander, Constrained by Precedent, 63 S. CAL. L. REV. 1, 13-16 (1989) (describing precedent as enhancing the reliance value and the value of general rules); Frederick Schauer, Precedent, 39 STAN. L. REv. 571, 595-97 (1987) (arguing that precedential constraint enhances fairness by ensuring consistency and predictability).

215 See Alexander, supra note 214, at 9-13 (arguing that reliance on precedent promotes equality); Schauer, supra note 214, at 596 ("Equality and precedent are thus, respectively, the spatial and temporal branches of the same normative principle of consistency.").

216 Kronman, supra note 213, at 1066.

217 The tension between the more philosophical arguments for stare decisis and Kronman's Burkean claim, however, has been used to describe tensions in our constitutional order present since the Founding. See James Q. Whitman, Why Did the Revolutionary Lawyers Confuse Custom and Reason? 58 U. CHI. L. REv. 1321, 1323 (1991). 
political life.”218 We respect past generations in hope that we might garner respect from future ones, but to merely worship the past contravenes our notions of reasoned political order.

Accordingly, we paint a partial picture of stare decisis. Consider the Court's discussion in Planned Parenthood of Southeastern Pennsylvania v. Casey. For the Court, "the very concept of the rule of law underlying our own Constitution requires such continuity over time that a respect for precedent is, by definition, indispensable." ${ }^{19}$ Although this might evoke Kronman's notion that historical fidelity confers contemporary meaning, the Court invoked "prudential and pragmatic considerations," grounded in utility and deontology. ${ }^{220}$ Three of the four Casey factors turn on utilitarian concerns about social order. The Court will abandon precedent if it is not workable, consistent, or legitimate. The fourth factor, reliance, draws on both utilitarian concerns and the deontological specter of inequity. ${ }^{221}$ Stare decisis, then, is required by reason; "no judicial system could do society's work," says the Court, "if it eyed each issue afresh in every case that raised it." ${ }^{222}$

Reason plays a somewhat counterintuitive role in the life of stare decisis. Kronman's view of stare decisis contravenes the view that we should structure society on the basis of reason alone rather than veneration for antiquity. Yet it helps to explain our veneration for the Constitution, a historical artifact central to our cultural understanding. The utilitarian and deontological defenses of stare decisis advance reason in their concern with stability and equality. Yet stare decisis undermines the project of vindicating a transcendent constitutional meaning. In the name of stability and equality, it allows departures from constitutional truth. As the Court affirmed in Casey, some departures may be too broad to allow. Other departures, however, stand.

Stare decisis, then, calls upon courts to heed legal fictions and legal myths and thereby uphold disjunctions introduced in the past. Whereas justiciability doctrine preserves the interpretive status quo by closing the courthouse doors, stare decisis preserves the interpretive status quo by confining the permissible interpretive arguments litigants may make before the court. Of course, we might view the Constitution as a living document explicated by judicial decisions. In this

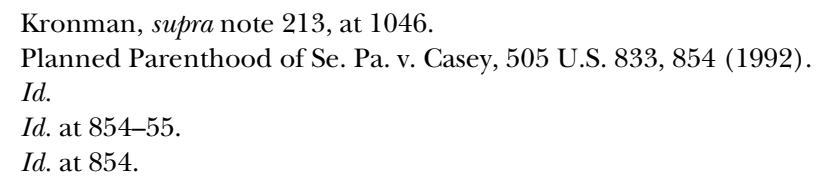


sense, recent history might be more foundational to constitutional meaning than distant history. Such a view, however, would not render stare decisis an instrument of conjunction rather than disjunction. To affirm past decisions would be to follow an interpretive theory. To follow stare decisis more broadly-and thus affirm past decisions when one's view of true constitutional meaning disagrees with them-would still perpetuate mythology and disjunction.

Stare decisis also calls upon courts to extend existing mythology and disjunction into new areas of the law. A present dispute may, upon occasion, mirror a prior dispute in every relevant detail. In such cases, a court that adheres to a prior holding despite its best judgment of the merits will preserve the mythology and disjunction introduced by the prior court. Many other disputes, however, will present similar yet distinct legal issues. The combination of stare decisis, analogical reasoning, and a commitment to coherence pushes courts to entrench mythology and disjunction in these cases. Inconsistent views of constitutional interpretation, moreover, can yield a patchwork of precedents dramatically at odds with one another. The task of reconciling these decisions may call for the introduction of new mythologies and thereby deepen existing disjunctions.

Perhaps it seems strange to cast stare decisis as contrary to the Enlightenment ideal if the Framers considered it a part of their constitutional order. Suppose you are an originalist and that the Framers advanced the same utilitarian and deontological arguments often raised to defend stare decisis today. Stare decisis might represent an important part of the constitutional mechanism. Why, then, would it contravene the Enlightenment ideal? Stare decisis allows our constitutional mechanism to consume itself through falsehood. It subjugates true constitutional meaning to considerations external to that meaning. If we take a wrong turn on the path to constitutional truth, we might find ourselves no longer bound by the same constitutional mechanism that validated stare decisis in the first place. In so doing, we would abandon our initial concern with factual accuracy or conceptual coherence. ${ }^{223}$

\section{Retroactivity}

Imagine that the Supreme Court recognized an error in a previous decision and, stare decisis notwithstanding, reversed the prior

223 That is, we would no longer be originalists in the relevant sense. Our adherence to stare decisis would lead us to abandon the interpretive mechanism that legitimated that very adherence. 
decision. It is not difficult to imagine such a situation. Imagine, moreover, that the Court did not overrule the prior decision as inconsistent with shifting public understandings. Rather, the Court said that the decision misconstrues the Constitution now and misconstrued the Constitution when it was decided. ${ }^{224}$ How should the Court's ruling affect litigants who brought claims under the old law? Should the new law be applied retroactively to the litigants now before the courts? What about litigants whose claims were already decided under the old law?

At common law, the answer to these questions was fairly straightforward. Indeed, the notion of retroactivity represents a modern construction. $^{225}$ The common law constituted an unchanging constant. If a court misconstrued the law, its decision was wrong. A party that litigated a case in which the court issued a new interpretation of the law was subject to the new interpretation. Likewise, parties in the midst of litigating the same claim when the court overruled past precedent would be subject to the new rule. A party whose claims had already been decided, by contrast, would be unable to reap the benefits of the new law. ${ }^{226}$ The results of past decisions would be final under res judicata and subject to very limited collateral attack. For convicted criminal defendants, habeas jurisdiction rarely allowed relitigating portions of the merits. ${ }^{227}$

The logic behind stare decisis seems to cut against both retroactive application of new law to pending litigation and bars against relitigating final decisions subject to discarded law. Stare decisis safeguards the public's reliance interest in the present law, but retroactivity frustrates the same interests for pending litigants. Stare decisis similarly safeguards the public's interest in intertemporal equality before the law, but the bar on relitigating final decisions frustrates this interest for parties subject to a final judgment. In tandem, these doctrines seem to present something of a paradox. If all litigants should be subject to the law at the time of the alleged harm, then courts should not apply new rules retroactively to pending liti-

224 See, e.g., Lawrence v. Texas, 539 U.S. 558, 578 (2003) ("Bowers was not correct when it was decided, and it is not correct today. It ought not to remain binding precedent. Bowers $v$. Hardwick should be and now is overruled.").

225 See Kermit Roosevelt III, A Little Theory is a Dangerous Thing: The Myth of Adjudicative Retroactivity, 31 ConN. L. REv. 1075, 1082 (1999) ("The concept of retroactivity is a relative newcomer to our jurisprudence.").

226 See id. at 1082-83 (describing how the consequence of the declaratory theory of the law is to eschew the concept of retroactivity).

227 For a discussion of habeas in the early republic, see Paul M. Bator, Finality in Criminal Law and Federal Habeas Corpus for State Prisoners, 76 HARV. L. REV. 441, 465-74 (1963). 
gants. If all litigants should be subject to the correct law, then courts should not bar reopening suits by those previously subject to the incorrect law.

This paradox did not take shape in the American legal mind until the mid-twentieth century. ${ }^{228}$ Two common law forces obscured it from view. First, the notion that the common law represented an unchanging force discerned by the courts rendered a distinction between old law and new law nonsensical. Reliance interests notwithstanding, courts could not apply a past, mistaken view of the law to pending litigants. If they did, courts would be allowing those litigants to evade the law. ${ }^{229}$ Second, common law constraints on collateral review removed most prior litigants from intertemporal concern. With habeas review limited to jurisdictional questions, courts did not face the issue of what substantive law should have applied to past decisions. New pronouncements about the law of jurisdiction would have applied to habeas petitioners, but such changes were relatively rare compared to changes in substantive law. ${ }^{230}$

As each of these forces shifted over time, so did views of retroactivity. If the law could change, it might make sense to honor reliance interests and apply the law at the time of the harm. With broader habeas review, moreover, it became thinkable that a court might break open a final judgment on the basis of the merits. The Supreme Court took up precisely these possibilities in the 1965 case Linkletter $v$. Walker. ${ }^{231}$ In Linkletter, a habeas petitioner sought to invoke a broader Fourth Amendment exclusionary rule adopted by the Court after his conviction became final. The Court held that new law applies to cases on direct review and that new law also may apply to cases on collateral review, subject to considerations of fairness and policy. Per Justice Clark, the Court created a three-factor test for said considerations: whether retrospective application would further the purpose of the invoked rule, the level of reliance placed upon the prior rule, and the effect of retrospective application on the administration of justice. ${ }^{232}$

\footnotetext{
228 For an overview of early discussions of the issue, see Beryl Harold Levy, Realist Jurisprudence and Prospective Overruling, 109 U. PA. L. REv. 1, 7-21 (1960).

229 That is, at common law, the past, mistaken law was simply not the law.

230 Notably, however, an individual convicted under a statute later deemed unconstitutional could bring a habeas petition for that reason in the early years of the Republic. Bator, supra note 227, at 471. As Bator writes, "In an era when law was not 'made' but 'found,' unconstitutional statutes were thought of as 'void,' as nonexistent, in a rather literal way: they created no law at all." Id.

231381 U.S. 618 (1965).

232 Id. at 629.
} 
The Linkletter decision garnered widespread criticism. ${ }^{233}$ Initially, the Court extended the decision's retroactivity analysis to habeas review and some portions of civil actions. ${ }^{234}$ Linkletter's three-factor test would govern retroactive application of new law for each cause of action. Ultimately, however, the decision and its progeny would represent a temporary departure from the common law approach to retroactivity. Behind a series of dissents by Justice Harlan, the Court reversed course. ${ }^{235}$ In the criminal and then civil contexts, it abandoned the Linkletter factors for cases on direct review. ${ }^{236}$ Whereas these decisions established a hard rule in favor of retroactivity on direct review, the Court effectively established a hard rule against retroactivity on collateral review. Once again abandoning the Linkletter factors, the Court recognized two narrow exceptions to the rule against retroactivity governing habeas petitions. ${ }^{237}$

Upon recognizing the paradox in common law retroactivity doctrine, the Supreme Court first eliminated it and then reintroduced it. The Court's rationale for eliminating the paradox turned on an aspiration for both correct decisions and intertemporal equality among litigants. True constitutional meaning, it reasoned, should be applied to all litigants before the courts. ${ }^{238}$ The Linkletter factors, howev-

233 See, e.g., Francis X. Beytagh, Ten Years of Non-Retroactivity: A Critique and a Proposal, 61 VA. L. REv. 1557, 1558 (1975) (observing that "[c]ommentators have had a veritable field day with" the Linkletter test); Herman Schwartz, Retroactivity, Reliability, and Due Process: A Reply to Professor Mishkin, 33 U. CHI. L. REv. 719, 720 (1966) (arguing that "all newly declared constitutional rights should be given retroactive effect").

234 See Chevron Oil Co. v. Huson, 404 U.S. 97, 100 (1971) (extending a variant of the Linkletter analysis to a civil case to determine the retroactive applicability of a Supreme Court decision concerning the applicability of state statutes of limitations under federal law); Stovall v. Denno, 388 U.S. 293, 294 (1967) (extending the Linkletter analysis to habeas petitions).

235 For a description of Justice Harlan's role in this reversal, see Roosevelt, supra note 225, at 1093-97.

236 See Harper v. Va. Dep't of Taxation, 509 U.S. 86, 90 (1993) (extending the rule in Griffith to all civil cases); Griffith v. Kentucky, 479 U.S. 314, 322 (1987) (holding that "failure to apply a newly declared constitutional rule to criminal cases pending on direct review violates basic norms of constitutional adjudication").

237 See Teague v. Lane, 489 U.S. 288, 307 (1989). The Court made two exceptions to this rule. First, new rules should be applied retroactively if they place "primary, private individual conduct beyond the power of the criminal law-making authority to proscribe." Id. (quoting Mackey v. United States, 401 U.S. 667, 692 (1971)). Second, new rules of criminal procedure should be applied retroactively if they are "implicit in the concept of ordered liberty" and contribute to the accuracy of the verdict. Id. at 311-12 (quoting Mackey, 401 U.S. at 693).

238 In exposing the fiction that the overruled decision must "be only a failure at true discovery and was consequently never the law," Linkletter aspired to devise a system that applied the proper law in a given case, whether it be a notion of the law since abandoned or a notion of the law rejecting some past notion of the law. Linkletter, 381 U.S. at 623. 
er, set limits on the applicability of true constitutional meaning. The Court's test promised intertemporal equality, but it raised the possibility of applying visions of the Constitution rooted in falsehood. Although the Court in Linkletter focused on questions of purpose and reliance, the third factor, concerning administration, loomed large. If the Court had found that the habeas petitioner in Linkletter could apply the new law, it would have faced thousands of similar petitions. It is not surprising that the Court ruled the other way. ${ }^{239}$

The Court did not view its subsequent retreat from Linkletter as reintroducing the paradox described above. Rather, it denied the presence of the paradox in the first place. Behind Justice Harlan, the Court revived an earlier, narrower vision of habeas that would not permit courts to reassess most constitutional claims on collateral review. ${ }^{240}$ Under this view, habeas petitioners may invoke subsequent decisions only rarely. Parties on direct review, by contrast, may not justify departures from the mandates of the Constitution by virtue of reliance interests. Accordingly, the Court's reversal reinstated a common law notion of retroactivity; intertemporal concerns about equality between prior litigants and present or future litigants seldom arise because habeas seldom implicates substantive constitutional questions. When habeas does implicate substantive constitutional questions, the Court has rarely allowed retroactive application of the law. ${ }^{241}$

Both of the Court's approaches contravene the Enlightenment ideal. Consider first the Linkletter regime. The Court's three-factor test allowed concerns about reliance interests and administrative burdens to outweigh constitutional truth. That is, for cases on direct and collateral review, Linkletter justified the continued application of law deemed to be riddled with mythology and disjunction. Now, consider the post-Linkletter regime. Although parties on direct review are subject to true constitutional meaning, those on collateral review remain, with few exceptions, bound by law once again riddled with mythology and disjunction. Whether a reviewing court views its role as

239 See Roosevelt, supra note 225, at 1091 (describing the Linkletter result as "almost inevitable" because otherwise there would have been "an avalanche of habeas petitions and new trials").

240 For an overview of the tightening of habeas jurisdiction since the 1970s, see Carol S. Steiker \& Jordan M. Steiker, The Seduction of Innocence: The Attraction and Limitations of the Focus on Innocence in Capital Punishment Law and Advocacy, 95 J. CRIM. L. \& CRIMINOLOGY 587, 609-18 (2005).

241 For a postmortem on the Court's retroactivity jurisprudence in cases where habeas petitioners sought to apply new rules of criminal procedure, see Note, Rethinking Retroactivity, 118 HARV. L. REV. 1642, 1652-56 (2005). 
engaging the constitutional merits or addressing narrower jurisdictional issues, petitioners must endure a legal standard recognized as incorrect. ${ }^{242}$ Res judicata requirements, moreover, preserve prior decisions based on mistaken views.

It may seem odd to imagine that the courts could reverse final civil judgments on the basis of changed understandings of constitutional meaning. Yet a commitment to eschew mythology and disjunction would not require that the courts retroactively apply all new understandings of constitutional truth. Depending on one's view from Sinai, constitutional meaning might legitimately change over time; if that were so, both the law applied in prior cases and the law applied in current cases would be correct. The cases at issue here are those in which a new understanding of constitutional truth casts doubt on their propriety as decided. Even for this smaller set of cases, the administrative burdens of reopening final judgments would be enormous. Surely, moreover, at some point we may prefer that the law be final rather than correct; ${ }^{243}$ uncertainty hinders our ability to plan for the future in both personal dealings and economic enterprises.

For the Enlightenment ideal, however, these are secondary concerns at best. The tenets of Enlightenment do not permit departures from true constitutional meaning, convenient or otherwise. Yet retroactivity doctrine has accepted such departures as a matter of convenience, perhaps even of necessity. Suppose that the Framers considered res judicata and non-retroactivity for collateral attack a vital piece of their constitutional mechanism. This does not change the fact that in many cases, these doctrines undermine the Enlightenment project of eschewing mythology and disjunction. Although non-retroactivity does not obstruct efforts to realize constitutional truth in future decisions, it preserves the interpretive failures that afflicted the past. In so doing, it gives past mythology and disjunction continued influence in the future.

\section{Dicta and Writing Separately}

The preceding common law doctrines each preserve mythology and disjunction in constitutional adjudication. The structure of common law judicial decisions, moreover, institutionalizes and legitimates those forces. This Part focuses on two common law phenom-

242 That is, a legal standard recognized as incorrect within a given constitutional theory.

243 As Justice Jackson eloquently put this preference, "[w]e are not final because we are infallible, but we are infallible only because we are final.” Brown v. Allen, 344 U.S. 443, 540 (1953) (Jackson, J., concurring). 
ena that illustrate this point: (1) the distinction between holding and dicta, and (2) the practice of writing separately. Although common law courts were ostensibly called upon to decide the legal issues necessary to resolve the dispute at hand, they often reached other issues as well. ${ }^{244}$ Courts composed of more than one judge, moreover, spoke in more than one voice; common law practice allowed each judge to deliver his opinion. ${ }^{245}$ Under the rule of stare decisis, both practices required subsequent courts to distinguish between binding law and merely instructive statements.

Each of these decisional doctrines has long been a part of our constitutional structure. Begin with writing separately. In the Early Republic, Chief Justice Marshall labored to eliminate the English practice of judicial opinions issued ad seriatim, consistently delivering decisions for a unanimous Court. ${ }^{246}$ He proved unable to cement this practice in the face of public criticism and dissenting justices, perhaps most notably Justice Johnson. ${ }^{247}$ In the years hence, separate opinions have been a consistent presence in judicial practice. Unlike their English predecessors, however, American courts have followed Marshall's call for a consistent judicial voice. When composed of multiple members, courts aspire to produce a single opinion for a majority. ${ }^{248}$ Plurality opinions garner consistent criticism. ${ }^{249}$ It is accepted, though, that single members of the court may write separately to concur or dissent in the reasoning or the result.

The distinction between holding and dicta recognized by American courts has similarly deep roots. In theory, the doctrine of stare decisis could call upon courts to defer, in the sense described above, to all legal conclusions reached by prior courts. At common law, however, stare decisis only attached to those conclusions essential to

244 Indeed, the emergence of a distinction between holding and dicta illustrates that courts often opined on matters subsequent courts would deem inessential.

245 See M. Todd Henderson, From Seriatim to Consensus and Back Again: A Theory of Dissent, 2007 SUP. CT. REV. 283, 292-303 (describing the British and early American practice of delivering judgments seriatim).

246 For an overview of Chief Justice Marshall's effort in this regard, see Charles F. Hobson, Defining the Office: John Marshall as Chief Justice, 154 U. PA. L. REV. 1421, 1442-50 (2006).

247 See generally Percival E. Jackson, Dissent in the Supreme Court: A Chronology 20-40 (1969).

248 In recent years, for example, Chief Justice Roberts has invoked the practice of the Marshall Court in asserting that his fellow Justices "should all be worried, when they're writing separately, about the effect on the Court as an institution." JEFFrEY ROSEN, THE Supreme Court: The Personalities and Rivalries that Defined America 7-8 (2006).

249 For an extreme view, see, for example, John F. Davis \& William L. Reynolds, Juridical Cripples: Plurality Opinions in the Supreme Court, 1974 Duke L.J. 59, 86 (stating that the "evil inherent in decision by plurality is not a minor one"). 
the elements of a prior decision reached by a majority of the court. ${ }^{250}$ In a regime governed by seriatim opinions, the task of distinguishing holding from dicta requires a careful reading of each of the opinions issued by the court. Plurality opinions require modern courts to engage in this type of analysis, but majority opinions make dividing holding from dicta more straightforward. The presumption against seriatim practice in our constitutional regime helps ease the task of distinguishing the essential elements of a decision from the inessential elements. ${ }^{251}$

Both of these common law forces envision legal interpretation as an iterative and uncertain enterprise. In a sense, the distinction between holding and dicta combines the rationales underlying justiciability doctrine and stare decisis. Although courts are bound by past decisions, they are only bound by those elements of past decisions thought to be within the bounds of judicial competence. ${ }^{252}$ That is, courts defer to past decisions only insofar as they resolve a confined and concrete dispute. The distinction between holding and dicta valorizes the notion that the law contains vast tracts of uncharted territory. Courts may opine about the contours of the law governing abstract disputes, but their opining does not bind with the force of law. The true content of the law, then, comes into view gradually but never completely. The path to that content is borne of restraint; no court may bind all others with its vision of true legal meaning. ${ }^{253}$

The practice of writing separately reinforces the value of iteration and uncertainty expressed in the distinction between holding and dicta. In a practical sense, signed opinions may improve the judicial work product by making judges accountable for their work. ${ }^{254}$ More

250 Although the definition of dicta may be simply stated, what constitutes an "essential" part of the prior decision is subject to serious debate. See, e.g., Michael Abramowicz \& Maxwell Stearns, Defining Dicta, 57 STAN. L. REv. 953 (2005) (providing a comprehensive framework for distinguishing holding from dicta); Michael C. Dorf, Dicta and Article III, 142 U. PA. L. REv. 1997, 1998 (1994) (discussing the "jurisprudential implications of Article III for determining how federal courts ought to distinguish between the holdings and dicta of past cases").

251 Of course, this presumption can only get us so far. We still encounter elaborately fractured opinions upon occasion. Consider, for example, the multiple majorities present in Regents of the Univ. of Cal.v. Bakke, 438 U.S. 265 (1978).

252 See Dorf, supra note 250, at 2053 (arguing that the distinction between holding and dicta helps "confin[e] the lawmaking authority of the courts to areas of their institutional competence").

253 For an articulation of this view, see Cass R. Sunstein, The Supreme Court 1995 TermForeword: Leaving Things Undecided, 110 HARV. L. REv. 4, 35-36 (1996).

254 See Ruth Bader Ginsburg, Remarks on Writing Separately, 65 WASH. L. Rev. 133, 139 (1990) ("Disclosure of votes and opinion writers may nourish a judge's ego, his or her sense of 
commonly, however, defenders of the practice invoke the power of separate opinions to promote judicial dialogue. To be persuasive, majority opinions must grapple with competing views. A majority of the court, moreover, may be willing to temper its decision to avoid the cloud of concurrence or dissent. ${ }^{255}$ The practice of writing separately does not only promote dialogue in individual cases; it also promotes dialogue between courts over time. In many cases, concurrences and dissents call upon future courts to cast aside stare decisis and correct the majority's departure from the true path. The law may be wrong today, but through iteration, it can work itself clean. ${ }^{256}$

Though ubiquitous, neither of these common law traditions has garnered universal acclaim. Criticism of the distinction between holding and dicta invariably turns to criticism of stare decisis. I am unaware of any scholars who contend that common law courts should afford equal deference to holding and dicta. To afford such deference to dicta would render present courts beholden to the whims of prior courts. ${ }^{257}$ Rather, scholars tend to criticize the prevalence of dicta in judicial opinions. Regardless of one's definition of dicta, it is often difficult to distinguish in practice between necessary and extraneous elements of a judicial decision. A liberal disposition toward dicta, therefore, poses two dangers. First, it may allow courts to obscure the true grounds of a legal decision. ${ }^{258}$ Second, it may mislead subsequent courts into misstating and misapplying the law. ${ }^{259}$ Both of these concerns call for minimal use of dicta rather than its abandonment.

individuality; but if our system affords the judge personal satisfaction, it also serves to hold the individual judge accountable.").

255 See William J. Brennan, Jr., In Defense of Dissents, 37 Hastings L.J. 427, 430 (1986) ("[T]he dissent is often more than just a plea; it safeguards the integrity of the judicial decisionmaking process by keeping the majority accountable for the rationale and consequences of its decision.").

256 See id. at 432 (describing how Justice Harlan's dissent in Plessy "spoke not only to his peers, but to his society, and, more important, across time to later generations").

257 Of course, civil courts afford equal deference to holding and dicta in that they afford no precedential value to either. See Merryman, supra note 184, at 48-51 (observing that, in contrast to common law systems, certainty in civil-law systems may not be achieved "by giving force of law to judicial decisions"). The point here is that once we afford deference to prior decisions, a "first in time" rule for judicial pronouncements could encourage judges to decide issues merely to bind their colleagues.

258 See Patricia M. Wald, The Rhetoric of Results and the Results of Rhetoric: Judicial Writings, $62 \mathrm{U}$. CHI. L. REV. 1371, 1411 (1995) ("[T] he core ruling of an opinion can be obscured or buried in too much talk, not keyed directly into the holding [itself].”).

259 See Nathaniel L. Nathanson, Mr. Justice Frankfurter and Administrative Law, 67 YALE L.J. 240, 249 (1957) (noting the "proclivity of ambitious dicta to mislead rather than illuminate"). 
Separate opinions have received more trenchant criticism. Much like liberal use of dicta, seriatim opinions obscure the rationale governing a particular case and increase the likelihood that subsequent courts will reach a mistaken view of the law. ${ }^{260}$ The single judicial voice found in civil-law traditions promotes a view of the law as determinate and uncontroversial. Separate opinions dramatize the possibility that reasonable minds may differ on legal meaning. This may be desirable for promoting dialogue about law. ${ }^{261}$ However, the splintering of a court invites comparisons between law and politics. As the Supreme Court reverses and re-reverses itself in opinions distinguishable only by the Court's membership, one may begin to doubt that true legal meaning exists at all. ${ }^{262}$ At the least, the fact that a concurrence or dissent may be vindicated down the road indicates that the prevailing view of legal meaning may be leading us astray. ${ }^{263}$

Consider these criticisms in the language of mythology and disjunction. The distinction between holding and dicta acknowledges that courts may stray from our visions of true constitutional meaning. Of course, the distinction seeks to insulate future decisions from this outcome. Yet the acceptance of dicta in the first place legitimates mythology and disjunction. Even though it is not governing law, dicta may introduce misunderstanding into the stream of the law. Dicta may obscure mythology and disjunction within an opinion, and it may promote such mythology and disjunction in succeeding opinions. Surely, dicta may clarify the law, even if it is not itself the law. Moreover, the nature of legal exposition makes it difficult to imagine that each thought in an opinion could be necessary to the holding. Yet the role of dicta in our constitutional order goes far beyond these justifications.

The practice of writing separately also acknowledges that courts may stray from true constitutional meaning. When a plurality opin-

260 See Henderson, supra note 245, at 298-99 (discussing the propensity for confusion that accompanies seriatim practice).

261 See generally Kevin M. Stack, Note, The Practice of Dissent in the Supreme Court, 105 Yale L.J. 2235 (1996) (asserting that the practice of writing dissents can be justified on the grounds of political legitimacy).

262 In this sense, even a single fractured decision, like Bush v. Gore, 531 U.S. 98 (2000), has the power to seriously damage the institutional legitimacy of the Supreme Court. See Jack M. Balkin, Bush v. Gore and the Boundary Between Law and Politics, 110 YALE L.J. 1407, 1450-58 (2001) (arguing that Bush v. Gore could harm the Court's legitimacy in the shortterm, but that the Court would probably recover in the long-term).

263 The "great dissenter" is a recurrent figure in our constitutional story; constitutional wrong-turns enter something of a constitutional "anti-canon," whereas dissents warning of the wrong-turn enter the canon. See generally Richard A. Primus, Canon, Anti-Canon, and Judicial Dissent, 48 DUKE L.J. 243 (1998) (discussing the "canonization" of dissents). 
ion obscures the holding of a case or yields mistaken views of the law in subsequent cases, it advances mythology and disjunction. When a court issues a majority opinion, separate opinions often charge that the majority opinion rests on mythology and disjunction. In such instances, separate opinions cannot introduce disjunction; they are not binding law. They may, however, introduce mythology that produces disjunction in a subsequent case. Separate opinions may also highlight that some members of a court subscribe to mythology that would produce disjunction if given legal effect. Indeed, the separate opinion institutionalizes recognition that the current law may rest on mythology and disjunction. In seeking to perfect the law of tomorrow, separate opinions raise doubts about the law of today.

To the extent that separate opinions and dicta generate dialogue about true constitutional meaning, they might reduce the prevalence of mythology and disjunction on net. Perhaps more importantly, however, the two common law practices expose mythology and disjunction enshrined by justiciability doctrine, stare decisis, retroactivity doctrine, and the like. In this sense, separate opinions and dicta highlight the distance between the Enlightenment ideal and the common law reality of our constitutional system. This does not mean that we recognize that distance; we may tell ourselves that the present mythologies and disjunctions are merely temporary departures from the truth. Yet it is out in the open for all to see.

\section{THE CUlTURE AND THE IDEAL}

In the last two Parts, I identified two strands of our constitutional discourse. First, I argued that constitutional theorists speak in the language of the Enlightenment ideal. That is, they condemn mythology and disjunction in an effort to discern constitutional truth and translate it into constitutional meaning. Second, I argued that constitutional theorists inhabit a constitutional system long pervaded by the common law culture. That system is quite opposed to the tenets of the Enlightenment ideal; it accepts mythology and disjunction as necessary elements of legal order. It follows that constitutional rhetoric about mythology and disjunction does not match the reality of constitutional practice. Or, to put the point another way, the Enlightenment ideal is itself a form of mythology.

In this Part, I outline three ways in which we might address the tension between the Enlightenment ideal and the common law culture. First, we might embrace one strand at the expense of the other. Call this the path of absolutism. Second, we might consciously reject each strand in favor of a hybrid of the two. Call this the path of rec- 
onciliation. Third, we might preserve a state of conflict like that present in the status quo. Call this the path of contradiction. I argue that constitutional scholars almost uniformly choose the path of contradiction; they espouse both the Enlightenment ideal and the common law culture without acknowledging or resolving the tension between them. Those who purport to follow the path of absolutism are not faithful to it, and followers of the path of reconciliation are few and far between.

\section{A. The Path of Absolutism}

A few scholars purport to follow the path of absolutism to either the common law culture or the Enlightenment ideal. In this Subpart, I examine two of the scholars most faithful to the path of absolutism in modern constitutional discourse: Ronald Dworkin and Cass Sunstein. Dworkin's notion of law as integrity flows in most regards from the Enlightenment ideal. Sunstein's notion of judicial minimalism captures the core of the common law culture. As we will see, even these exemplars of the absolutist path are not quite absolutist in their adherence to either the common law culture or the Enlightenment ideal. Like other scholars inclined toward absolutism, Dworkin and Sunstein occupy the fringe of constitutional discourse, albeit an oftdiscussed fringe.

Begin with Dworkin. In many ways, Dworkin's notion of constitutionalism echoes the Enlightenment project championed by the Framers. The task of the interpreter is to uncover the natural constitution of the political body. Or, to use Dworkin's words, the task for the interpreter is to divine "the principles of justice, fairness, and procedural due process that provide the best constructive interpretation of the community's legal practice." ${ }^{264}$ The range of permissible interpretations, however, is limited by familiar constraints. First, the interpreter must arrive at constitutional meaning from first principles rather than policy or intuition. ${ }^{265}$ Second, the interpreter may only reach first principles that "fit" the facts that underlie her legal order. $^{266}$ Third, the route to principle as opposed to policy rests in a

DWORKIN, LAW's EMPIRE, supra note 46, at 225.

For a discussion of this distinction, see RONALD DWORKIN, TAKING RIGHTS SERIOUSLY 8288 (1977).

266 Dworkin introduces this concept in the context of constitutional adjudication. See id. at 106 (arguing that an interpreter must look to constitutional rules and settled practices to see which of a set of competing constitutional theories "provides a smoother fit with the constitutional scheme as a whole"). For a general discussion, see DWORKIN, Law's 
test of coherence, or what Dworkin has called "articulate consistency. ${ }^{267}$ Let us unpack these three requirements further.

Dworkin's effort to distinguish between policy and principle recalls Wechsler's aspiration for neutral principles of constitutional law. Whereas arguments of policy seek to protect a "collective goal of the community as a whole," arguments of principle demonstrate that a decision "secures some individual or group right." 268 The latter form of argument can only succeed when "the principle cited can be shown to be consistent with earlier decisions not recanted, and with decisions that the institution is prepared to make in ... hypothetical circumstances. ${ }^{269}$ Dworkin's Hercules must begin this project anew with each dispute before him; the pursuit of first principles never ceases. Of course, a perpetual return to first principles begs the question of constraint. An interpreter might encounter a plethora of viable first principles. Dworkin's initial response lies in morality; the interpreter, he says, is to justify our legal order so that it is best. ${ }^{270}$

Surely, abstract morality is not much of a constraint. Beneath Dworkin's appeal to morality, however, rests a set of more specific requirements concerning factual accuracy and conceptual coherence. As to fact, Dworkin requires that interpretive conclusions follow from the facts underlying the interpreter's political community. Hercules may not impose upon that community his own view of a desirable constitutional order; his theory must justify existing "political history" and perpetuate existing "community morality." Dworkin reads a requirement of global coherence into his notion of first principles. Each decision must be consistent with a "comprehen-

EMPIRE, supra note 46, at 227-28 ("History matters because that scheme of principle must justify the standing as well as the content of these past decisions."). 267 DWORKIN, TAKING RIGHTS SERIOUSLY, supra note 265, at 88 (arguing that consistency
"means consistency in the application of the principle relied upon, not merely in the application of the particular rule announced in the name of that principle").

$269 \quad I d$. at 88.

270 See DwORKIN, LAW's EMPIRE, supra note 46, at 225-27 (laying out Dworkin's theory of "law as integrity," which "insists that legal claims are interpretive judgments and therefore combine backward-and-forward-looking elements; they interpret contemporary legal practice seen as an unfolding political narrative"); DWORKIN, FREEDOM's LAW, supra note 44 , at 7-12 (asserting that a "moral reading asks [judges] to find the best conception of constitutional moral principles"). "According to law as integrity," Dworkin writes, "propositions of law are true if they figure in or follow from the principles of justice, fairness, and procedural due process that provide the best constructive interpretation of the community's legal practice.” DWORKIN, LAW's EMPIRE, supra note 46, at 225. 
sive theory" of the law, a "seamless web" of legal meaning. ${ }^{272}$ This is a broad requirement; Hercules must uncover principles "that fit, not only the particular precedent to which some litigant directs his attention," but all other judicial decisions and statutes in his jurisdiction "so far as these must be seen to be generated by principle rather than policy.",73

In some realms, Dworkin's theory eschews the mythology and disjunction of the common law culture. Take precedent. For Dworkin, interpreters must account for past decisions in their efforts to divine a coherent legal system. Past decisions, however, do not bind interpreters in the manner of common law stare decisis. Precedent informs interpretive efforts to ensure consistency and coherence; it does not foreclose inquiries into legal meaning. ${ }^{274}$ Dworkin argues that a theory that "designates part of what is to be justified as mistaken is prima facie weaker than one that does not." Hercules must show that an interpretive theory that casts past decisions as mistaken "is nevertheless a stronger justification than any alternative that does not recognize any mistakes, or that recognizes a different set of mistakes." ${ }^{276}$ In this sense, precedent checks the personal convictions of the interpreter, but not her inquiry into first principles, factual accuracy, and structural coherence.

In other realms, however, Dworkin's theory leaves open the possibility of mythology and disjunction. Hercules would probably decry much of justiciability doctrine as unprincipled, but Dworkin does not engage the topic. He emphasizes that judges must respect institutional role, but it is not clear whether that role incorporates a common law notion of adjudication. Dworkin implies that it does, noting that Hercules must sometimes accept "substantive inconsistency to keep faith with more procedural principles" given the "complex character of adjudication." ${ }^{277}$ Dicta and the practice of writing separately seemingly raise the same possibility, yet Dworkin also does not engage them overtly. In the case of retroactivity, Dworkin is a more explicit apologist for mythology and disjunction. He claims that law

\footnotetext{
$272 I d$. at 87,116 . Given the difficulty of this task, Dworkin quips, "You will now see why I called our judge Hercules." Id. at 116. 
as integrity dictates that decisions are correct as decided and thereby ignores whether they should ever be revisited. ${ }^{278}$

Let us turn to Sunstein. Whereas Dworkin exalts theory, Sunstein exalts what we might call anti-theory. For him, the task of interpretation is not one driven by the promise of first principles or a particular type of constitutional clarity. The "judicial mind," he argues, "naturally gravitates away from abstractions and toward close encounters with particular cases." ${ }^{279}$ Sunstein has set out to legitimate that disposition, which he locates within the common law tradition. Like Edmund Burke, with whom Sunstein has identified in recent years, ${ }^{280}$ he has developed something of a theory against theory. His argument does not exhibit the structural coherence of Dworkin's. Rather, Sunstein's defense of "judicial minimalism" represents a collection of pragmatic considerations oriented toward stability and order. ${ }^{281}$ The result is an embrace of elements of the common law culture and derision for abstraction in constitutionalism.

Sunstein's approach to constitutionalism echoes Bickel's, but it exhibits important differences. Whereas Bickel envisioned the Supreme Court as uniquely capable of advancing principle, Sunstein distrusts the notion of principle in judicial interpretation. ${ }^{282}$ For Sunstein, judicial appeals to principle threaten democratic choice, the institutional capacities of courts, and social stability more broadly. Sunstein argues that courts should only decide issues necessary to resolve a case or controversy, and they should justify their decisions with as little abstraction as possible. ${ }^{283}$ To use Sunstein's terms, judi-

278 For a discussion of the implications of Dworkin's theory on retroactivity, see generally Kenneth J. Kress, Legal Reasoning and Coherence Theories: Dworkin's Rights Thesis, Retroactivity, and the Linear Order of Decisions, 72 CALIF. L. REV. 369 (1984).

279 CASs R. Sunstein, One CASE AT A Time: Judicial MinimalisM On the Supreme CourT, at xi (1999).

280 See generally Cass R. Sunstein, Burkean Minimalism, 105 MiCH. L. REV. 353 (2006) (defending a Burkean approach to constitutional interpretation that he argues is both rooted in our constitutional system and desirable in instances when originalism produces intolerable results, established traditions are just, and judicial competence is limited).

281 Sunstein acknowledges, however, that this pragmatism cannot be fully divorced from theory, as "the strongest defenses of judicial minimalism must themselves be theoretical in character." SunSTEIN, ONE CASE AT A TIME, supra note 279, at 248.

282 According to Sunstein, "Bickel erred in seeing the Court as having a systemically better understanding of 'principle,' than other branches." Id. at 267 n.5.

283 Sunstein argues that incompletely theorized agreements "are especially well suited to the institutional limits of the judiciary, which is composed, in significant part, of multimember bodies, consisting in turn of highly diverse people who must render many decisions, live together, avoid error to the extent possible, and show each other mutual respect.” Cass R. Sunstein, Incompletely Theorized Agreements, 108 HARV. L. ReV. 1733, 1738 (1995). 
cial decisions usually should be shallow rather than deep and narrow rather than wide. ${ }^{284}$ Together, these guidelines leave questions of principle to democratic processes, confine judicial inquiry to a manageable scope, and avoid the divisiveness and turmoil that often accompanies assertions of first principles. ${ }^{285}$

Although Sunstein attacks reasoning from first principles, he does not single out the remaining two tenets of the Enlightenment ideal for criticism. Indeed, his attack on first principles derives its force from claims that courts construct a more coherent and factually based constitutional order when they eschew abstraction. Confined judicial inquiries, he argues, ensure that decisions are grounded carefully in facts. ${ }^{286}$ Limits on abstraction, he argues, ensure that decisions are consistent with the body of existing law. ${ }^{287}$ Yet, in preaching against theory and breadth, Sunstein implicitly defends some incidence of mythology and disjunction. In leaving things undecided, courts preserve mythologies that underlie prevailing constitutional practice. In avoiding abstractions, courts evade inquiries that may reveal mythology. For Sunstein, then, pragmatic concerns suggest that we allow some past falsehoods to persist into the present. ${ }^{288}$

The tools of Sunstein's judicial minimalism are those of the common law culture. Sunstein does not derive these tools from scratch; rather, he accepts them as the substance of our legal order. His notion that courts should leave things undecided incorporates the common law case-or-controversy requirement enshrined in justiciability doctrine. ${ }^{289}$ Stare decisis governs Sunstein's approach to shallow and narrow decisions; the allure of not deciding rests in that we "must take precedents as fixed points" in our constitutional system. ${ }^{290}$ Sunstein does not engage retroactivity doctrine, yet it is equally central in his conception of constitutional interpretation; once cases are decided, they become the fixed points of precedent, not to be revisited except under extraordinary circumstances. The practices of writ-

284 shallowness and depth are always appropriate, but he argues for a strong presumption in its favor.

285 See id. at $46-54$

286

See id. at 252-55 (arguing that "an assessment of facts may well aid in the achievement of incompletely theorized agreements," which may "be shallow when they are a product of an understanding of facts"). See id. at 255-58.

As Sunstein acknowledges, "If the concern is not the process but the substance-getting democracy's content right-it is possible that judicial minimalism will be all wrong." Id. at 55 .

Id. at 39-40.

Sunstein, Incompletely Theorized Agreements, supra note 283, at 1761. 
ing separately and distinguishing holding and dicta, moreover, receive particular emphasis in Sunstein's account. These practices, he argues, function to both highlight deviant judicial overstep and contain its effects moving forward. ${ }^{291}$

Like Dworkin, however, Sunstein does not fully commit to an absolutist vision. He seeks "a presumption rather than a taboo against high-level theorization." ${ }^{292}$ It is not quite clear when Sunstein would allow courts to turn to first principles. He argues that "fuller theorization-in the form of wider and deeper inquiry into the grounds for legal judgment-may be valuable or even necessary to prevent inconsistency, bias, or self-interest." ${ }^{293}$ Recently, Sunstein has argued that courts should neither follow a Burkean commitment to tradition nor follow a rationalist skepticism of tradition. ${ }^{294}$ Surely, these claims are not entirely at odds with traditional common law interpretation; common law courts change course and synthesize bodies of legal doctrine. Sunstein accepts, however, limits on minimalism that recall the Enlightenment ideal. He defends an interpretive method that allows mythology and disjunction, but he also defends departures from that method for the purpose of eschewing mythology and disjunction.

\section{B. The Path of Reconciliation}

As we have seen, Dworkin and Sunstein stray from the path of absolutism. Although both scholars elevate either the common law culture or the Enlightenment ideal, neither elevates his preferred intellectual strand to the complete exclusion of the other intellectual strand. In so doing, both Dworkin and Sunstein follow one of the paths competing with absolutism. Sunstein follows the path of reconciliation. His approach to constitutional interpretation selfconsciously blends elements of the common law culture and the Enlightenment ideal. Dworkin, by contrast, follows the path of contradiction. His approach to constitutionalism blends elements of the common law culture and the Enlightenment ideal, but claims that it does not. Let us first consider reconciliation.

The idea that we might reconcile the common law culture and the Enlightenment ideal may seem perplexing. Whereas the Enlighten-

291 Sunstein singles out the distinction between holding and dicta in his discussion of minimalism. See, e.g., Sunstein, ONE CASE AT A Time, supra note 279, at 4-5.

292 Sunstein, Incompletely Theorized Agreements, supra note 283, at 1767.

293 Id. at 1750.

294 See generally Sunstein, Burkean Minimalism, supra note 280 (asserting that Burkean minimalism may not be appropriate in the context of constitutional law and should be rejected when traditions are discriminatory). 
ment ideal disallows mythology and disjunction, the common law culture allows them. How can these two strands possibly be reconciled? Two possibilities come to mind. First, we might segment them. That is, we might follow the common law culture in some areas of the law and follow the Enlightenment ideal in other areas. ${ }^{295}$ This approach would allow mythology and disjunction, but it would cabin the reach of the common law culture. Second, and more counter-intuitively, we might combine them. That is, we might believe that adherence to the Enlightenment ideal requires adherence to the common law culture. This approach would allow some mythology and disjunction, but only to further a longer-term project of eschewing deeper mythologies and disjunctions.

Take first the approach of self-consciously employing the Enlightenment ideal and the common law culture in different segments in our legal order. This is Sunstein's approach to reconciliation. Sunstein argues that constitutional interpretation should be narrow and shallow, but he labors to define situations in which width and depth are appropriate..$^{296}$ This is an argument for a flexible adherence to common law mechanisms that allows the Enlightenment ideal to trump upon occasion. David Strauss provides a second example of this flavor of reconciliation. Strauss argues that the common law method defines the contours of our constitutional system, but only up to a point. The constitutional text, he argues, grounds constitutional discourse in both some notion of principle and some level of concreteness. For Strauss, the text "serves as a convention, a focal point of agreement" within the chaos of the accumulated wisdom legitimated by the common law method. ${ }^{297}$ Accordingly, his account balances invocations of principle and common law appeals to settled practice.

295 Indeed, the law is not quite as far from this state of affairs as it may seem at first glance. Antitrust law, for example, is something of an island of the Enlightenment ideal. See, e.g., Steven C. Salop, The First Principles Approach to Antitrust, Kodak, and Antitrust at the Millennium, 68 ANTITRUST L.J. 187, 187 (2000) (arguing that antitrust law nimbly returns to questions of economic first principle rather than taking a "wooden approach" to economic reasoning).

296 See Sunstein, One Case at a Time, supra note 279, at 57 (arguing that "it is worthwhile to attempt a broad and deep solution (1) when judges have considerable confidence in the merits of that solution, (2) when the solution can reduce costly uncertainty for future courts and litigants, (3) when advance planning is important, and (4) when a maximalist approach will promote democratic goals either by creating the preconditions for democracy or by imposing good incentives on elected officials").

297 David Strauss, Common Law, Common Ground, and Jefferson's Principle, 112 YALE L.J. 1717, $1732(2003)$. 
Now, take the approach of combining the ideal and the culture. The leading proponent of this view is Bickel. For Bickel, the common law culture enables the Supreme Court to safeguard aspirations of Enlightenment. Bickel would not have framed his views this way; like Sunstein, he ultimately grounded his constitutional theory in Burkeanism. ${ }^{298}$ In The Least Dangerous Branch, however, Bickel did not disclaim a place for the tenets of Enlightenment. Instead, he argued that the pursuit of principle must fail if it is a slave to itself. ${ }^{299}$ Bickel's famous "passive virtues" describe a form of adherence to common law instruments of minimalism. ${ }^{300}$ While these instruments are "not themselves principled," Bickel argues, they allow the Court to render "principled adjudications" when it chooses to decide. ${ }^{301}$ Prudence, not principle, must determine the path of adjudication; principle is a "universal guide," but it is not a "universal constraint." principle in the long run, then, we must employ non-principle.

As these examples suggest, the path of reconciliation is trod primarily by those disposed toward the common law culture. ${ }^{303}$ The Enlightenment ideal does not provide the same leeway for compromise; it speaks of fixed principles, whereas the common law culture's commitment to muddling through is spread across a range of pragmatic doctrines. Yet, even among those disposed toward the common law culture, the path of reconciliation is not a popular one. Sunstein claims that his theory of constitutional interpretation describes the analysis genuinely employed by courts. This ignores, however, the Enlightenment rhetoric that has long accompanied our constitutional enterprise. Courts may proceed in a manner consistent with Sunstein's theory, but their language is more complicated; oftentimes, it is hardly the language of reconciliation. The same applies to scholarly visions of constitutional interpretation. Our con-

298 AleXANDER M. Bickel, The Morality of CONSENT 3 (1975) (identifying with eighteenthcentury Whigs and Edmund Burke).

299 BICKEL, supra note 53, at 244 (arguing that "the rule of principle in our society is neither precipitate nor uncompromising, that principle may be a universal guide but not a universal constraint, that leeway is provided to expediency along the path to, and alongside the path of, principle, and, finally, that principle is evolved conversationally not perfected unilaterally").

300 See id. at 111-18 (discussing mechanisms for avoiding decision, including standing doctrine, ripeness doctrine, and the related political-question doctrine).

301 Id. at 205.

302 Id. at 244

303 See, e.g., Charles Fried, The Supreme Court 1994 Term-Foreword: Revolutions?, 109 HARV. L. REV. 13, 16 (1995) (arguing that we should be wary of "calls to examine, or reexamine, first principles" that "raise the specter or embrace the exhilaration of radical rethinking"). 
stitutional discourse does not sound in reconciliation, but rather in contradiction.

In a sense, this is not surprising. Effectively segmenting the common law culture and the Enlightenment ideal is an unenviable task. Sunstein advances a series of factors to consult as to whether a return to first principles is appropriate. ${ }^{304}$ It is difficult to imagine a satisfying way to segment these two traditions in a manner that is not just weakly suggestive, like Sunstein's. Vagueness yields an imprecise division, and an imprecise division reproduces the contradiction. Similarly, Bickel's notion that principle requires unprincipled behavior does violence to deep-seated Enlightenment values about transparency and coherence. Few scholars have defended his view of prudence, and many have lined up to criticize it. ${ }^{305}$ Moreover, both approaches highlight an unsettling contradiction long associated with our understanding of constitutionalism. Accordingly, the contradiction persists, albeit largely hidden from view.

\section{The Path of Contradiction}

Like Sunstein, Dworkin describes his interpretive theory as the analysis genuinely employed by courts. Sunstein argues that, contrary to the public imagination, courts do not rely on theory in constitutional interpretation. $^{306}$ Dworkin argues that, again contrary to the public imagination, courts do not ignore theory. ${ }^{307}$ One might wonder how the public could hold such contradictory notions of constitutional interpretation. Yet there is indeed contradiction in how scholars and courts navigate the boundaries between the common law culture and the Enlightenment ideal. It is not merely that the culture and the ideal have coexisted since the Founding. The two traditions have been apparent within the theories of constitutional meaning espoused by most participants in constitutional discourse. That is, the Enlightenment ideal does not emerge as a myth solely upon viewing

304 SunStein, ONE CASE AT A TIME, supra note 279, at 57 (looking to (1) judicial confidence in the merits, (2) whether a broad and deep decision would reduce costly uncertainty, (3) whether advance planning is important, and (4) whether a broad and deep decision would advance democratic goals).

305 See supra note 136 and accompanying text.

306 Sunstein argues that, "as a general rule, those involved in constitutional law tend to be cautious about theoretical claims." SunSTEIn, ONE CASE AT A Time, supra note 279, at xi.

307 According to Dworkin, "[1] awyers and judges, in their day-to-day work, instinctively treat the Constitution as expressing abstract moral requirements that can only be applied to concrete cases through fresh moral judgments." DWORKIN, FrEEDOM's LAW, supra note 44 , at 3 . He argues, however, that "it would indeed be revolutionary for a judge openly to recognize the moral reading." Id. 
our constitutional system as a whole; it emerges within nearly every theory of constitutional meaning that makes up that system.

To see this, begin again with the Marshall Court. Amidst Marshall's rhetoric about reasoning to constitutional truth, lay the assumption that adjudication should follow the common law model. The Court invoked antecedents of justiciability doctrine, traditional notions of precedent, the distinction between holding and dicta, and the practice of writing separately. ${ }^{308}$ In so doing, it likely followed the "poorly-digested farrago of ideas, without inner logic," that animated the Framers. ${ }^{309}$ Under many interpretive theories, the Court's embrace of common law mechanisms was less a choice than a requirement. ${ }^{310}$ Requirement or not, the result combined Enlightenment rhetoric and common law constraints. The Court simultaneously promoted and assailed mythology and disjunction. It championed an abstract notion of constitutional principle while simultaneously restricting its ability to recognize and affirm that principle.

The notions of maintenance advanced by mid-nineteenth century theorists also betray an uneasy mingling of the tenets of Enlightenment and the dictates of the common law culture. In his Commentaries, for example, Justice Story located the "permanent principles" of constitutional government in common law notions of "[o] ur ancestors." ${ }^{311}$ He did not explain why the common law would ensure such principles, nor did he contend, like Bickel, that genuine principle demands short-term departures from principle. Similarly, John Norton Pomeroy both invoked first principles to reach "the truth ... of the meaning of the Constitution" "312 and derided "impracticable theorist $[\mathrm{s}]$ " that would do such a thing. ${ }^{313}$ Modern descendents of these thinkers follow a similar pattern. Justice Scalia invokes

308 See, e.g., Cohens v. Virginia, 19 U.S. (6 Wheat.) 264, 405 (1821) (stating that the case-orcontroversy requirement in Article III limits the judicial power to "'a case in law or equity,' in which a right, under such law, is asserted in a Court of justice”); Alexander v. Balt. Ins. Co., 8 U.S. (4 Cranch) 370, 379-82 (1808) (declining to follow dicta); Ex Parte Bollman, 8 U.S. (4 Cranch) 75, 87-90 (1807) (invoking stare decisis). For a discussion of the practice of writing separately in the Marshall Court, see supra notes 246-249 and accompanying text. I do not mention retroactivity because that issue did not arise for the Marshall Court given its Blackstonian view of the law. See supra notes 225-227 and accompanying text.

309 Whitman, supra note 217, at 1367-68.

310 That is, for theories that rely on some notion of original understanding, it would appear that the Marshall Court acted appropriately in implementing that understanding. Of course, this quickly becomes something of a Pandora's box. Which common law mechanisms did the Framers agree upon? What would have constituted agreement? And so on.

3111 STORY, supra note 116 , at $\$ 377$.

312 POMEROY, supra note 117 , at $\S 148$.

313 Id. at $\S 140$. 
original intent as true constitutional meaning, but he confines his inquiries such that he often cannot reach that meaning. ${ }^{314}$

The opposite pattern emerges among adherents to accounts of constitutional growth. Although these theorists embrace the common law culture, they ground that embrace in Enlightenment rhetoric. For Sidney George Fisher, the limits of human reason suggest that "the only safe foundation for government is custom" and gradualism. ${ }^{315}$ He seeks to legitimate this view through what is, in essence, an appeal to the first principles of the Founding. Fisher finds that the first principles of the Founding disclaimed first principles: "Our ancestors," he argues, "followed the English model as closely as they dared, not perhaps as closely as they wished." ${ }^{316}$ C.G. Tiedeman and Woodrow Wilson similarly defend a system of common law growth on the grounds that it is dictated by the essence of our national character. ${ }^{317}$ While these theorists invoke Enlightenment rhetoric in discerning constitutional meaning, their conclusions eschew the Enlightenment ideal for the common law culture. They call upon us to follow their prescriptions, but not their pattern of inquiry. Indeed, they ignore the tension between these two strands.

Consider once again the rise and fall of Lochner. Although the judges that would enshrine Lochner invoked first principles, they did not do so in every case or with respect to every issue. Their decisions very much inhabited the common law culture. To employ a frame advanced by Richard H. Fallon, Lochner represents an "extraordinary case" in the sense that the Court saw it as a case that required an inquiry into first principles of constitutional governance. ${ }^{318}$ Yet, in many "ordinary cases," the Court carried the torch of traditional

314 It is in this sense that Scalia is a "faint-hearted originalist." Scalia, supra note 50, at 864. Not only does Scalia ignore original intent in some instances given his moral intuitions, as he acknowledges, but he also prevents himself from engaging a full inquiry into original intent.

315 FISHER, supra note 120 , at 17.

316 Id. at 24.

317 See Tiedeman, supra note 122, at 16 ("The constitution of a state may be described as the definition of the order and structure of the body politic, while constitutional law consists of those fundamental principles and rules in accordance with which the government is constructed and orderly administration is conducted. Constitutional law may be described as the anatomy and physiology of the body politic."); WILSON, supra note 123, at 4 (arguing that "the right of those who are governed to adjust government to their own needs and interests" is demonstrated in the Declaration of Independence). 318 Richard H. Fallon, Jr., The Supreme Court 1996 Term — Foreword: Implementing the Constitu-
tion, 111 HaRv. L. REv. 54, 60 (1997). Fallon distinguishes between "ordinary" cases in which "the Court applies the framework established by prior decisions" and "extraordinary" cases in which the Court turns to a "fresh examination of underlying "first principles"” to address the issue. Id. at 60-61 
common law adjudication, invoking stare decisis, minimalism, and the like. ${ }^{319}$ The New Deal decisions that overturned Lochner follow the same pattern. As it reversed course, the Court spoke of transcendent principle. Yet it did not really return to first principles. Rather, it left most of the existing constitutional superstructure both intact and unquestioned. ${ }^{320}$ In these two shifts, the Court did little to explain the line between an ordinary case and an extraordinary one. Rather, it proceeded as if the two genres of cases were one and the same: a product of longstanding principle.

Post-war constitutional theorists betray the same disconnect between rhetoric and reality. Although Herbert Wechsler's pursuit of neutral principles evokes the language of Enlightenment, Wechsler carefully noted that it could not displace common law notions of precedent. Adherence to precedent need not hinder the task of pursuing neutral principles; precedent may play a role in assessing neutrality in much the same way it plays a role in Dworkin's notion of integrity. Yet Wechsler does not make this argument. Instead, he merely cites Holmes' remark that "imitation of the past, until we have a clear reason for change, no more needs justification than appetite." ${ }^{321}$ John Hart Ely reproduces a comparable dynamic. Ely reasons to a vision of constitutional meaning that sounds in the Enlightenment ideal, yet he expresses concern about projects that seek to uncover fundamental principles. The result at once appeals to abstract reason and denigrates claims that "have the smell of the lamp about them." ${ }^{322}$ Neither theory negotiates a relationship between culture and ideal; both leave their tension unacknowledged.

Contemporary theorists espouse the Enlightenment ideal while tacitly advancing the common law culture. Return to Ackerman and Michelman. Ackerman has self-consciously taken up the cause of Enlightenment. The Framers, he says, "were hardly content with the Burkean arts of muddling through crises." ${ }^{\text {"233 }}$ Through the notion of extra-textual amendment, Ackerman repackages the apparent contradictions of our constitutional order into a coherent system dominated by the will of the people. Still, his account does not fully es-

319 Indeed, these strands are the substance of Justice Holmes' famous dissent in Lochner. See Lochner v. New York, 198 U.S. 45, 76 (1905) (Holmes, J., dissenting) (arguing that "[g]eneral propositions do not decide concrete cases").

320 For one of the most far-reaching accounts of the New Deal revolution, see 2 BRUCE ACKerman, We The People: Transformations 255-311 (1998).

321 Wechsler, supra note 52, at 17 (quoting Oliver Wendell Holmes, Holdsworth's English Law, in Oliver Wendell Holmes, Collected Legal PAPERs 285, 290 (1920)).

322 ELY, supra note 137, at 59.

3231 ACKERMAN, supra note 31, at 20. 
chew the "muddling through" of the common law culture. The people may speak outside of Article V, but courts interpret their utterances subject to the forces of common law adjudication. ${ }^{324}$ In many ways, Michelman echoes Dworkin in his devotion to principle, albeit through dialogue. For him, "[e]very norm, every time, requires explanation and justification in context" through the "practical reason" of dialogue. ${ }^{325}$ Like Dworkin, however, Michelman does little to address common law adjudication or how it may confine the dialogue he describes. ${ }^{326}$

A clear picture emerges: constitutional theorists promote the Enlightenment ideal as a legal myth. A study of nearly any opinion interpreting the Constitution reveals that courts are hardly engaged in the enterprise of discerning transcendent constitutional meaning. Behind the court's discussion, lies a vast landscape of assumptions it refuses to engage. The litigants know that they may not question that landscape; they make their cases within the confines of the common law culture. Scholars dissect cases within those confines. Yet, when it comes to abstract discussions of constitutional meaning, rhetoric does not match reality. The falsehood of the Enlightenment ideal, once uncovered, is readily apparent. But, like the myth that law follows rules, the Enlightenment ideal reflects a desire transformed into belief. $^{327}$ It is not advanced as a convenient falsehood; it is advanced as a precondition for intelligent discourse about constitutional meaning.

Michelman, supra note 54 , at 76 .

Michelman locates the common law culture within the nomos of our constitutional culture. He states

Judicial self-government, like all self-government, can occur only within a nomos, a cognizable normative universe that makes integrity conceivable. In our judicial nomos there are strong norms of popular sovereignty, intragovernmental division of responsibility, and justice to parties-all of which demand attention to statutes, regulations, constitutional texts, precedents, and other embodiments of history.

Id. In the next breath, however, he states that "[t]he norm of justice to parties itself commands that no other norm should ever take a form that preempts questions or exempts reason-giving." Id. In this statement, Michelman affirms the Enlightenment ideal.

327 As Karl Llewlyen argued in 1934, "the theory that rules decide cases seems for a century to have fooled not only library-ridden recluses, but judges." Llewelyn, supra note 146, at

7. This desire, he argued, became a belief that altered the reasoning of decisions [f] or when changes in common law cumulate to the point where even the willful blind may be expected to perceive the change, some judge rewords 'the' rule into a wholly different rule tailored more neatly to the current course of decision: one more device to save the face of an insolvent theory.

$I d$. at 10. Nearly a century later, constitutional theorists continue to warn of the same selfdelusion. See, e.g., Robert C. Post, The Supreme Court 2002 Term-Foreword: Fashioning the Legal Constitution: Culture, Courts, and Law, 117 HARV. L. REV. 4, 111-12 (2003). 
This is, no doubt, quite a strange state of affairs. It is not only that the Court adheres to the common law culture within plain view; stare decisis, after all, is not a phrase known only to lawyers. The ideological divisions on the Court, aired in recurrent 5-4 decisions in highprofile cases, cast serious doubt on the notion that our constitutional system is moored to some abstract truth. Yet, as we have seen, doctrines like stare decisis can be employed within a theory of constitutional meaning; ideological divisiveness, moreover, can be blamed on the ideological opponent: if only they followed true constitutional meaning, there would not be such divisions. The confirmation process for Supreme Court justices dramatizes these strands. Much is said of stare decisis and ideology. But these discussions serve as a protracted effort of disclaiming the plausibility of deep interpretive agreement, restating the myth. ${ }^{328}$

\section{THE IDEAL AS BENEFICIAL LEGAL MYTH}

Is this state of affairs desirable? Perhaps this seems like the wrong question. The task of constitutionalism, after all, is to enshrine a constitutive mythology. Good, bad, or otherwise, our constitutive mythology constitutes our constitutional system. This response, however, ignores that arguments about constitutional theory necessarily involve considerations of their consequences. ${ }^{329}$ Accordingly, we must wrestle with the value of maintaining the Enlightenment ideal as a legal myth rather than rendering it a legal fiction, disclaiming it, or disclaiming the common law culture. This tradeoff is not easily avoided; after all, the Enlightenment ideal's status as a legal myth runs counter to an ideal central to our constitutional discourse: the Enlightenment ideal.

Although we must question our constitutive mythology, we cannot ignore it. It is the backdrop against which discussion of our constitutional system takes place. As I have argued, the common law culture and the Enlightenment ideal are firmly ingrained in our constitutional discourse. Theorists who purport to embrace the Enlightenment ideal still recognize the conversational constraints of the common law culture. Theorists who claim adherence to the common law

328 For a telling account, see Elena Kagan, Confirmation Messes, Old and New, 62 U. CHI. L. REv. 919, 920 (1995) (book review) (arguing that the "nonanswer" discourse employed in the confirmation processes of Justices Ginsburg and Breyer raise more concerns than the politicized discourse employed during Robert Bork's failed confirmation process).

329 For a discussion of these considerations, see generally Richard H. Fallon, Jr., How to Choose a Constitutional Theory, 87 CALIF. L. REV. 535, 537 (1999). 
culture nonetheless invoke Enlightenment to allay concerns that our constitutional order may take a wrong turn. The few theorists that have sought to blend these traditions have garnered few followers. We need not accept the present expression of these patterns of constitutional engagement, but it would be foolish to imagine that we might change them on a whim.

With this in mind, let us return to each of the three paths described above: absolutism, reconciliation, and contradiction.

Begin with absolutism. From the foregoing, it should be clear that absolutism is a non-starter; this path wholly rejects our affinity for either the culture or the ideal. Even supposing that such a wholesale rejection could actually be achieved, moreover, neither the common law culture nor the Enlightenment ideal is an obvious choice. The debate between Sunstein and Dworkin illustrates the point. If we embraced the ideal, we would need to accept considerable legal instability and profound problems of judicial competence. If we embraced the common law culture, we would need to accept falsehood and inconsistency in constitutional interpretation. Surely, tradeoffs like these are familiar. Suffice it to say that neither culture nor ideal is self-evidently superior to the other and neither paints a satisfying picture in isolation. In light of our collective unease with the absolutist path, it does not seem to be the best choice.

Turn, then, to the path of reconciliation. This path is a nonstarter for many of the same reasons. Neither of the routes to reconciliation described above envisions a genuine exchange between the culture and the ideal. Sunstein divides the two strands topically; he sets boundaries by subject matter to govern whether we should follow culture or ideal. Bickel divides the culture and the ideal temporally; he defends the culture as a short-term tool that enables us to fulfill the ideal in the long term. These solutions do not resolve the underlying tension between culture and ideal. Rather, they compartmentalize the two strands. This is understandable; the culture and the ideal are diametrically opposed and thus defy reconciliation of any other kind. The trouble with compartmentalization, however, is that it merely reproduces absolutism within compartments. For reconciliation to work, we must be willing to accept absolutism within certain boundaries.

So long as we can agree on the rationale for a division, a patchwork of absolutist compartments may be desirable. This would allow us to reap some benefits of both the culture and the ideal. It is not clear, however, that we can craft boundaries in a manner that is precise and satisfying. Precision is necessary for genuine compartments; imprecise divisions will yield conflict at the borders. Boundaries must 
be satisfying so that we can live with them despite our conflicting allegiances to the culture and the ideal. Neither Sunstein nor Bickel parts culture from ideal with precision; Sunstein advances a vague list of factors to govern when to invoke first principles, and Bickel does not elaborate when we should follow principle and when we should not. Needless to say, neither scholar's divisions have proved satisfying to other scholars. This is unsurprising; if there is a satisfying way to precisely divide the inherently imprecise conflicts between truth and stability, depth and simplicity, and consistency and expediency, it has not revealed itself.

This leaves the path of contradiction. The path of contradiction surely holds some allure; it allows us to reap the benefits of both the culture and the ideal without needing to navigate compartmentalization. But, this path has difficulties of its own.

Before we address them, let us first divide it into two sub-paths: that of patent contradiction and that of latent contradiction. This division is straightforward; the patent contradiction is readily apparent to the public, while the latent contradiction goes undetected. In the case of the patent contradiction, we might identify the contradiction in constitutional discourse or we might collectively recognize its presence even as it is nominally denied. That is, the patent contradiction might be denoted as such or it might be recognized in a manner similar to a legal fiction. In the case of the latent contradiction, the contradiction must evade public notice; it can be neither overtly identified nor implicitly recognized. The latent contradiction, then, evokes a dynamic similar to the legal myth. Contradiction presents difficulties in both its latent and patent forms.

First, consider patent contradiction. The trouble with this subpath is that it would expose disjunction at the core of most, if not all, of our theories of constitutional meaning. This is true for theories that profess allegiance to the Enlightenment ideal as well as theories that profess allegiance to the common law culture. For theories that profess allegiance to the Enlightenment ideal, it would expose the fact that constitutional practice is confined by the common law culture. For theories that profess allegiance to the common law culture, it would expose the fact that the common law culture is not always so rigid a constraint. In each case, we would see that the relevant theories do not follow their own commands, at least as the theories conceive of them. For theories that profess allegiance to some combination of the culture and the ideal, this sub-path will also yield disjunction. There is a difference between reconciliation and contradiction; such theories would thus fail to heed their stated interpretive approach. 
Of course, this sub-path would not expose disjunction in a constitutional theory that called for contradiction. For example, a theory might demand that we pay obeisance to the Enlightenment ideal but hew close to the constraints of the common law culture. In such case, there would be no disjunction; the path of contradiction would be the path dictated by the constitutional theory. On some level, most constitutional theories, at least as described here, may seem to follow this mold. We might say, then, that the path of contradiction would reveal conjunction rather than disjunction. These theories do not see themselves as favorable to contradiction, however. That is, they fail to recognize that they embrace contradiction. According to their terms, therefore, taking this sub-path would reveal disjunction, not conjunction. As should be clear from the preceding Parts, I am unaware of any constitutional theory that so embraces contradiction.

Consider an example of this dynamic. Suppose you are an originalist. You say that you are committed to an Enlightenment-style inquiry into the intent of the framers. In practice, however, you confine your analysis in accordance with the common law culture. If we expose this contradiction, we will reveal that your interpretive approach does not follow the mantra it espouses. We would not be revealing a disjunction in the formal criteria your theory employs to resolve a particular case. Rather, we would reveal that you do not actually advance the constitutional meaning dictated by original intent. We would reveal that you place roadblocks into your analysis that foreclose the possibility of arriving at that aim. Even if these roadblocks are consistent with the intent of the Framers, they foreclose your ability to vindicate their full constitutional vision. ${ }^{330}$

What is so bad about exposing a disjunction like this one? Exposed disjunctions threaten the stability of a legal order for two primary reasons. First, they cast doubt upon the notion that a constitutional system follows an internal system of meaning. If our constitutional theories do not follow their own demands, we must begin to ask ourselves whether our constitutional order is anything

330 Justice Scalia acknowledges that

[i] $\mathrm{n}$ its undiluted form, at least, [originalism] is medicine that seems too strong to swallow. Thus, almost every originalist would adulterate it with the doctrine of stare decisis—so that Marbury $v$. Madison would stand even if Professor Raoul Berger should demonstrate unassailably that it got the meaning of the Constitution wrong.

Scalia, supra note 50, at 861. Accordingly, Scalia might respond that the mantra of his notion of originalism is not original intent but rather originalism with stare decisis. This belies, however, the rhetoric of originalism: that true constitutional meaning lies in original intent. Scalia's concern for precedent allows a departure from that meaning. 
more than the bald exercise of power. In this sense, disjunction attacks the bonds that makes constitutionalism possible. ${ }^{331}$ Second, exposed disjunctions cast doubt upon the notion that a constitutional system can follow an internal system of meaning. If a theory cannot follow its own commands, we must ask ourselves how we can call upon the notion of constitutionalism to bind us together into selfgovernment. If we conceive of constitutionalism as a project that generates a shared system of meaning, this type of disjunction challenges the notion that constitutionalism could ever be possible, except perhaps in the most homogenous of societies. ${ }^{332}$

Now, consider the path of latent contradiction. The great benefit of the latent contradiction is that it obscures these disjunctions. This benefit, however, comes at the cost of honesty and transparency. There are three scenarios in which we would fail to perceive the contradiction between the common law culture and the Enlightenment ideal. First, we might believe that we follow the common law culture even though we do not. Second, we might believe that we follow the Enlightenment ideal even though we do not. Third, we might simply fail to recognize the tension between our allegiances to the culture and the ideal. The third scenario may seem the least troubling, as it appears to rely on ignorance more than delusion. Yet it is also the least plausible; if unhidden, the contradiction between the culture and the ideal is hard to ignore. That is, latent contradiction would seem to require collective delusion of some sort. ${ }^{333}$ Accordingly, we

331 For a discussion of the strands in constitutional discourse that police this division, see Richard H. Fallon, Jr., "The Rule of Law" As a Concept in Constitutional Discourse, 97 Colum. L. REV. 1 (1997). The literature on this division is immense, but the idea is fairly simple: our constitutional order depends on some understanding that ours is a system "of laws, and not of men." Marbury v. Madison, 5 U.S. (1 Cranch) 137, 163 (1803). As Fallon writes, a central element of the modern accounts of the rule of law is that "[p] eople must be able to understand the law and comply with it." Fallon, supra, at 8 . When a theory does not follow its own requirements, its account of law detracts from such understanding.

332 As Robert Cover argues, different communities generate systems of meaning that, "[1] et loose, ... would be unstable and sectarian in their social organization, dissociative and incoherent in their discourse, wary and violent in their interactions." Cover, supra note 7, at 16. Constitutionalism polices these interactions, whether it be through a homogenous hierarchy of values, or by legitimizing sub-communities within a larger framework. Id. at 67-68. Exposed disjunction poses two threats in this regard. First, it challenges the ability of a constitutional order to mediate between the sub-communities and currents that inhabit a society. Second, it challenges the ability of sub-communities to generate a sustainable system of meaning. Together, these two forces threaten the disintegration of both the whole and its parts.

333 Or, at the very least, ignoring the contradiction would require such a cognitive dissonance that in essence we would either be subscribing to one of these false beliefs or subscribing to both of them at different points in time. I do not delve into the possibility 
must consider the tradeoff between false belief in the culture and false belief in the ideal.

False belief in the common law culture would have few advantages. It would eschew the notion that our constitutional order rests on first principles. Instead, we would see constitutionalism as an incremental project of muddling through. There would be no such thing as a wrong turn, at least as measured against deeper principles of meaning. In practice, of course, constitutionalism would return to first principles occasionally. A false belief in the preeminence of the common law culture would help legitimate these breaks with past practice, because they would be largely beyond attack once achieved. Adherence to the common law culture would also allay concerns about judges rejecting longstanding practices in the name of abstract notions of constitutional meaning. It is difficult to imagine, however, that our constitutional system would adopt a false belief in the common law culture given the Founding's Enlightenment rhetoric. It is also difficult to imagine that this false belief would not be exposed for its falsehood. The most recognizable constitutional acts are those that break with the past.

False belief in the Enlightenment ideal evades these potential pitfalls. The ideal has deep roots in our origin myths. It also compliments our penchant to notice the extraordinary rather than the pedestrian. More than that, false belief in the Enlightenment ideal carries considerable benefits; namely, it preserves the appearance that our constitutional order rests on principle. This has two primary effects. First, it counters concerns that constitutionalism is the bald exercise of power. The Enlightenment ideal supports the notion that there is a correct answer to a constitutional question that derives from a consistent theory of meaning. ${ }^{334}$ Second, it obscures irreconcilable value conflicts that, if exposed, would cast doubt upon the possibility of constitutionalism as a collective enterprise. The En-

that subscribing to both of these false beliefs at different times might be a better course than consistently subscribing to one of them. Such fragmented contradiction would be difficult to discuss cogently; there are so many possible permutations that weighing them within this calculus would be near impossible. Accordingly, I assess the two extremes of subscribing to either the common law culture or the Enlightenment ideal as legal myths. I note here, however, that given my view that the ideal is on balance the better legal myth, I would imagine that if we advanced each of the legal myths in different contexts, adherence to the ideal as legal myth would generally be preferable.

334 Although this notion is often seen as quaint if not dangerous, it is a recurrent desire in our constitutional discourse. For a critique of the idea that there can be a correct answer to a constitutional question, see, for example, DANIEL A. FARber \& SUZANNA SHERrY, Desperately SeEking Certainty: The Misguided Quest for Constitutional FOUNDATIONS (2002). 
lightenment ideal allows us to believe that apparent rejections of our core values are mere missteps that fail to capture the true meaning of our constitutional system. ${ }^{335}$ These two benefits smooth over weaknesses in our constitutional order that are threatened by the possibility of exposed disjunction.

As a legal myth, the Enlightenment ideal generates a narrative that preserves the possibility that a wide array of constitutional viewpoints will be vindicated. When we see a decision that contravenes our vision of constitutional meaning, we hold out hope that it will be reversed in short order. We may even enter the courts to ensure that it is reversed. If time passes and the decision remains binding law, we may consider either amending the Constitution or amending our constitutional theory. The decision might cast portions of our theory into doubt, but it need not cast doubt on the notion of fidelity to genuine constitutional meaning; vindication is always around the corner. $^{336}$ This conviction allows us to preserve both an essential appearance of consistent constitutional meaning and an essential ambiguity in the content of that meaning. Together, these forces enable constitutional legitimacy amidst profound contestation of constitutional meaning.

Let us pause on the assertion that our constitutional democracy requires a certain ambiguity. It is fairly uncontroversial that ambiguity is sometimes necessary to strike a compromise between competing viewpoints. ${ }^{337}$ The ambiguity I refer to here is more complex, howev-

335 Guido Calabresi has described this possibility with particular eloquence. In some instances, he writes

one must seek solutions in which-though one set of ideals and beliefs will win the particular case (that cannot be avoided) - the victory will not reject as invalid or outside our law the ideals, beliefs, and values (yes, even the metaphysics) of the losing group. Because such solutions respect both the winning and the losing metaphysics, they look to a time when it may be possible to accommodate both sets of beliefs. Even if such a time never comes to be, they serve to place the burden of the immediate result on all of us rather than just on the losers.

Guido Calabresi, Ideals, Beliefs, Attitudes, and the LaW: Private LaW Perspectives ON A Public LaW Problem 97-98 (1985).

336 In a sense, the notion of "democratic constitutionalism" is a conscious expression of the process in which groups affirm their collective hope that true constitutional meaning is just around the corner. See Robert Post \& Reva Siegel, Roe Rage: Democratic Constitutionalism and Backlash, 42 HARV. C.R.-C.L. L. REv. 373, 375 (2007) (arguing that "[w] hen citizens speak of their most passionately held commitments in the language of a shared constitutional tradition, they invigorate that tradition" such that "even resistance to judicial interpretation can enhance the Constitution's democratic legitimacy").

337 This does not mean that these legislative compromises are particularly celebrated. See, e.g., Joseph A. Grundfest \& A.C. Pritchard, Statutes with Multiple Personality Disorders: The Value of Ambiguity in Statutory Design and Interpretation, 54 STAN. L. REv. 627, 628 (2002) (defending ambiguous legislative compromises and noting that formal legal doctrine 
er; it encompasses an intertemporal ambiguity. As Calabresi and Bobbitt have argued, some value conflicts must be obscured from collective consciousness such that the social fabric does not rip apart. An ambiguous compromise cannot obscure such conflicts so long as it is perceived as a compromise. ${ }^{338}$ The Enlightenment ideal preserves a healthy sense of intertemporal uncertainty. Even if a group believes an interpretation rejects its most foundational values, the ideal helps preserve the group's faith that those values will be vindicated eventually. A decision may expose the conflict, but its conclusions are merely a temporary articulation of a deeper, contested, constitutional meaning. ${ }^{339}$ A commitment to vindicating true constitutional meaning binds us together even as irreconcilable value conflicts threaten to tear us apart. ${ }^{34}$

Of course, there are limits to the benefits of the Enlightenment ideal as legal myth. Although it may help legitimate the constitutional enterprise, the Enlightenment ideal paints the courts as a political battleground where the battle is never truly won. In this sense, the Enlightenment ideal may actually threaten the view that our constitutional order is based in principle; it leads us to contest articulations of constitutional meaning. ${ }^{341}$ Moreover, given that the common law culture enshrines views we sometimes believe misconstrue true constitutional meaning, it is difficult to ignore that our constitutional order

"frames legislative ambiguity as a problem to be solved rather than an opportunity to be exploited").

338 Calabresi and Bobbitt argue that to resolve choices between resource allocations that implicate irreconcilable values, we "must attempt to make allocations in ways that preserve the moral foundations of social collaboration" in ways that "do[] not appear to implicate moral contradictions." CALABRESI \& BOBBITT, supra note 166, at 18. However, "unless the values held in tension have changed, the illusion that denies their conflict gives way and the transformation will only have been a postponement. When actions are again focused on the tragic choice, action will again be required." Id.

339 In this sense, the Enlightenment ideal achieves precisely what Calabresi calls for in clashes between moral beliefs: it "preserves the moralisms which lose out in the conflict." CALABRESI, supra note 335 , at 92 . It is not only that "the loser may be more willing to accept the loss if losing does not mean that society will become callous to the values he or she held." Id. Even the appearance of a final decision, in light of the Enlightenment ideal, may always be subject to question.

340 To make this cohesion possible, courts must give voice to the rejected constitutional meanings, such that proponents of the vindicated meaning might reconsider their views. For an intricate discussion of the way in which the Court can show us how "opportunities for communal reconciliation might be grasped," see Robert A. Burt, Constitutional Law and the Teaching of Parables, 93 YALE. L.J. 455, 502 (1984).

341 And, it leads us to ask, like Charles Fried, if we can place decisions by the Court's "liberal and conservative [voting] blocs" within "any coherent set of doctrinal or jurisprudential principles." Charles Fried, Five to Four: Reflections on the School Voucher Case, 116 HARV. L. REV. 163, 195 (2002). 
does not actually follow the Enlightenment ideal. That realization threatens to prompt disillusionment with our constitutional processes. $^{342}$ Moreover, the temporal ambiguity enabled by the Enlightenment ideal can only do so much as time passes. Even if we believe that our view of true constitutional meaning will be vindicated, we may need to endure such prolonged rejections of a foundational value that it becomes clear that the society we inhabit is no longer of the Constitution to which we adhere. ${ }^{343}$

Perhaps worse, the Enlightenment ideal as legal myth is, nonetheless, a legal myth. In some sense, it is a lie, even if a lie that we turn upon ourselves. ${ }^{344}$ For some, rooting out dishonesty may be the first priority, consequences be damned. ${ }^{345}$ This is a tough position to argue against. All one can say is that the Enlightenment ideal as legal myth, dishonesty and all, may be the best way to navigate the tension between our allegiance to Enlightenment principle and the common law culture. We can only reach this conclusion through a weighing of the importance of honesty, so there is no foolproof way to defend the Enlightenment ideal as legal myth against this attack. A proxy, however, lies in the constitutive mythology we have built around constitutionalism since the Founding and that we continue to build today. The falsehood inherent within the Enlightenment ideal has been readily apparent since the Founding. It is the substance of nearly every discussion of legal doctrine, whether the doctrine is gnarled or straightforward. Yet we continue to avert our eyes. We repeat the old pleasantries, and the legal myth persists.

This dynamic should help reduce concerns about the Enlightenment ideal as legal myth and highlight its strengths. Surely, we may train an unhealthy amount of attention on the workings of the Supreme Court, and we may descend occasionally into the throngs of legal nihilism. On the whole, however, faith in the presence of principle beneath our constitutional system has helped weather irrecon-

342 If not, indeed, a descent into legal nihilism. See generally Joseph William Singer, The Players and the Cards: Nihilism and Legal Theory, 94 YALE L.J. 1, 5 (1984).

343 Consider, for example, the suspension of disbelief required for abolitionists and civilrights activists to struggle for a vision of the Constitution compromised by slavery and segregation.

344 See, e.g., "A man who lies to himself is blameworthy because he acts with knowledge of the facts and thus may be held responsible for his erroneous belief." Raphael Demos, Lying to Oneself, 57 J. PHIL. 588, 589 (1960)).

345 Kant's view of lying follows this mold. See Christine M. Korsgaard, The Right to Lie: Kant on Dealing with Evil, 15 PHIL. \& Pub. AfF. 325, 326 (1986). For a more recent, if less categorical, critique of lying, see Sissela BoK, Lying: Moral ChOICE In Public AND PRIVATE LIFE (1978). 
cilable constitutional disagreements and maintained social confidence in a larger constitutional enterprise. It has done so even when that faith is not quite warranted-even when our individual constitutional theories are recognizably inconsistent and our collective constitutional doctrine is recognizably incoherent. In this, there is reason to the apparent un-reason of the contradiction between the Enlightenment ideal and common law culture, and there is reason to the delusion that allows that contradiction to persist.

\section{CONCLUSION}

Suppose, then, that you have begun your descent from Sinai. I have argued that you would be ill-advised to reveal the legal myth of the Enlightenment ideal. If there is one legal myth that would be best left unmentioned, perhaps there are more. Indeed, I have argued that the legal myth of the Enlightenment ideal obscures legal myths that pervade all of our theories of constitutional interpretation. Your views on this, of course, will depend on your view of the truth about our constitutional enterprise and how that truth translates into constitutional meaning. In this Article, I have necessarily made claims about constitutional truth, though I have labored to make those claims as minimal as possible. I have sought to avoid all claims about constitutional meaning. It is you, after all, who is empowered by the vision on Sinai. Or, if not by the vision on Sinai, some vision nonetheless. Of course, your vision may cast doubt on my vision. To this, I have no response. I can only hope that my limited vision can withstand yours.

You may wonder why I would labor to expose a legal myth only to argue that it remain unexposed. The importance of the Enlightenment ideal as legal myth does not depend upon a total lack of awareness. It depends on our collective persistence in leaving it generally unacknowledged and unnoticed. This does not mean that constitutional theorists should wholly ignore it. In seeing the contradiction between the common law culture and the Enlightenment ideal, the constitutional theorist may grapple with how to address the dilemmas of constitutional interpretation it circumscribes. Or, she may labor, my views notwithstanding, to transform our constitutional order such that it would hardly resemble our present order. Perhaps you find it troubling that these two possibilities do not envision a collective constitutional conversation. This is natural. As I have argued, we value both truth and obscurantism. It should not be surprising that both of these forces would even shape how we address our engagement with them. 